\title{
JAVAANSCHE WETTEN
}

DOOR

C. POENSEN.

"JavaANsche WeTten, en andere bepalingen, geldig in Jogjakarta, ten dienste van Landhuurders, Beheerders en Geëmployeerden van ondernemingen en van de Javaansche ambtenareu in dat gewest." - "Vertaald, verzameld en bewerkt door G. J. Oudemans,

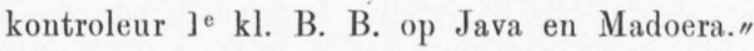

"Dit werk bestaat uit twee deelen; een Hollandsche tekst vormt "het eerste, een Javaansche het tweede deel.

"Dit laatste is weer in twee stukken verdeeld, waarvan het "eene de Oude Javaansche, het tweede de Nieuwere Javaansche "Wetten en Verordeningen bevat."

Door het bovenstaande weten wij, met welk werk wij hier te doen hebben. Het bevat niet anders dan Javaansche Wetten en Verordeningen (gedeeltelijk in Hollandsche Vertaling) allen in Ngajogyåkartå geldig, (en voor een deel ook in Soeråkartå) die de Uitgever verzameld heeft, niet voor Juristen, maar voor Europeanen, welke bij den Landverhuur in dat Vorstendom geïuteresseerd zijn, en voor Javaansche Ambtenaren. Toch hebben deze Wetten voor die Juristen, welke de Javaansche taal voldoende machtig zijn, ongetwijfeld hare eigenaardige waarde; doch inzonderheid voor hen die de Javaansche taal- en letterkunde beoefenen; en ook zij die de Land- en Volkenkunde van Java beoefenen kunnen hier nog wel iets van hunne gading vinden.

Van deze gedachten doordrongen, gaf T. Roorda reeds in 1844

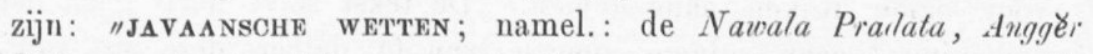
Sadasa, Anggěr Agěng, Anggěr Goenoeng en Anggër Aroeliroe" uit. Deze vijf wetten, plus de Anggð̌r Pradata Akir, vormen het 2e Deel 
(Jav. tekst) van des heeren Oudemans' uitgave, waarvan het $1^{\mathrm{e}}$ Deel de vertaling geeft. De A. Agĕng, A. Aroebiroe en A. Pradata Akir heeft de heer $O$. zelf vertaald; de vertaling der A. Goenoeng en $A$ Sapoeloel, is van de hand des heeren Rosemeier, en die der Nawala Pradlata Awal overgenomen uit D. L. Mo unier's: "Het boek der Nawolo-Prarlhoto met vertaling en aantt. Batavia Landsdrukkerij 1844."

Als men nu den Jav. tekst van R.'s uitgave in 1844 vergelijkt met dien van den heer O., komt men al spoedig tot de wetenschap, dat beide teksten, hier meer daar minder, nog al van elkaar onderscheiden zijn. De $A$. Aroebiroe bijv. bij R. bevat slechts 4 . artikelen (waarvoor in de Aanteeken. achter zijn werk nog al uitvoerige toevoegselen gegeven worden), en die bij O. heeft 26 Artikelen. En ook de inhoud dier Artikelen verschilt nog al. Genoeg om te doen blijken, dat de Uitgave van den heer O. een zelfstandigen arbeid aanbiedt, en zeker boven de uitgave van $R$. is te schatten. De heer O. was daarbij in de gelegenheid ons de meest-juiste lezing dezer Wetten te bezorgen, en heeft zich daarvoor ook zeer veel moeite gegeven. In een particulier schrijven deelde de heer $\mathrm{O}$. ons o. a mede: "Zoo was nergens een compleet exemplaar van de $A$. Aroebiroe te vinden, totdat eindelijk de translateur te Solo mij daaraan hielp. De overige vijf zijn, als ik mij wel herinner, alle gecopieerd (namelijk met verbetering der tallooze Jav. taal- en spelfouten) van het officieele exemplaar, dat bij den Rijksbestierder berustte." Dat desniettegenstaande de Tekst nog hier en daar te wenschen overlaat, bètreurt de heer $O$. evenzeer, doch is minder hem te wijten, dan wel de omstandigheden waaronder de uitgave plaats had.

De heer O. heeft de $A$. Aroebiroe bet eerst in den bundel opgenomen. "Deze wet is thans geheel in onbruik geraakt. Volledigheidshalve is zij in dit werk opgenomen." Van al deze oudere wetten kan in het algemeen gezegd worden, dat zij "grootendeels" in onbruik zijn geraakt, want "zij worden wel degelijk nog wel eens geraadpleegd, vooral in quaesties, die in de nieuwere verordeningen niet voorkomen." (O.) " $\mathrm{Na}$ onderling overleg van den Rijksbestierder te Ngajogyåkartå, Raden Adipati Danoe Rĕdjå, en dien te Soeråkartå, Raden Adipati Såsrådiningrat, werd deze wet voor beide Rijken aangenomen." De tekst zelve heeft geen dagteekening, maar volgens opgave van $O$. dateert deze wet van 5 Bĕsar, Ehe, $1708=11$ November 1782. - Deze Wet is, evenals 
de $A$. Agèng en de $A$. Sactísü in Kråmå gesteld; en de A. Pradáti Akir, de Nawilli Praulitia Dalèm en de $A$. Goenveng in Ngoko.

Iemand, die geheel met Java en Javaansche toestanden onbekend is, zal over een Art. 4 als in dit wetboek voorkomt, zich allicht verwonderen. Het heeft tot opschrift: Over het dragen nan door den Vorst verboten kleederen. Komt iemand van Ngajogyå in Suråkartå, of omgekeerd, met kleederen die daar door den Vorst verboden zijn, dan worden hem die kleedingstukken afgenomen en verbeurd verklaard. De grenzen, waar dit verbod begint, worden daarbij nauwkeurig opgegeven.

De tweede Wet, de A Praditi Akir "is mijn wetboek, Ing kang Sinuhun, Kangdjĕng Sultan Amĕngku Buwånå, Senåpati ing ngalågå, Ngabdurrahman, Sajiddin Panåtågåmå, Kalipatollah ing nungswå Djåwå te Ngajogyåkartå voor mijn onderdaan den Tumĕnggung Niti Prådjå gedagteekend Zaterdag-Wage, 11 Ruwah, Wawu, $1713=28$ Juni 1787." Deze wet is dus geldig voor Ngajogyå, en moest dienen tot wetboek voor Niti Prådjå, die den rang bezit van Wadånå-djakså, of hoofd van het Openbaar Ministerie, met verschillende ambtenaren onder zich. (Zie: "De Inlandsche Rangen en Titels op Java en Marlvera door Mr. L. W. C. van den Berg." Batavia Landsdrukkerij 1887, p. 58.)

Omtrent de te berechten zaken zegt Art. 1:

"De zaken die berecht worden zijn: straatroof, veediefstal, diefstal, ontfutseling, berooving met geweld, plundering, brandstichting, geschillen over eigendomsrechten, misbruik van vertrouwen, paud- en schuldzaken ${ }^{1}$ en dergelijken. De Tumĕnggung Niti Prådjå zal deze zaken berechten, geheel naar recht en billijkheid, in algemeene overeenstemming met al zijn medeleden, ( waarvoor O. "ondergeschikten" heeft.)

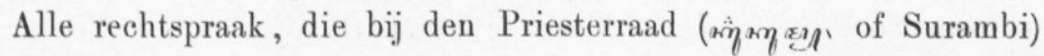
thuis behoort en door deze kan berecht worden, sta ik niet toe dat door mijn Pradåtå (inlandsche rechtbank voor burgerlijke en strafzaken) afgedaan worde; die moet voor den Priesterraad gebracht worden. Maar het is ook zeer goed, als geschillen tusschen gehuwde lieden, huwelijks- en erfenisquaesties niet ingebracht worden door tusschenkomst van den Lawang (een rechterlijk amb-

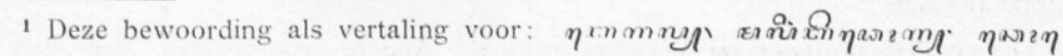

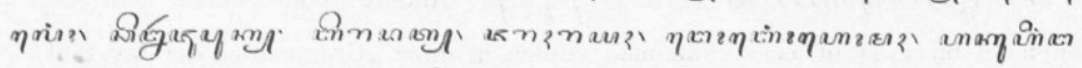

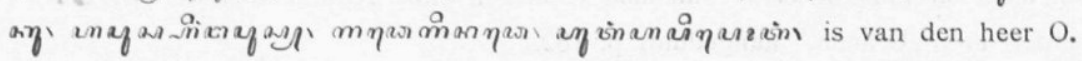


tenaar, nevens eenen Djakså, bij wien de stukken inkomen en die ze expedieert. Zie: Nawålå Pradåtå Dalĕm. Art. 34. ${ }^{1}$

Zaken nu, die natuurlijk niet thuis behooren bij den Priesterraad, zooals: wanneer iemand als aanklager optreedt doch er is geen beklaagde (gedaagde); of als er iemand gedagvaard is doch deze zich intusschen heimelijk uit de voeten heeft gemaakt; of als er een manslag, waarvan het lijk gevonden wordt, heeft plaats gehad, waarvoor het gebied waar het lijk gevonden wordt verantwoordelijk is, doch de moordenaar niet bekend is, of iemand dien men als verdachte zou kunnen opvatten - deze zaken moeten door den Pradåtå afgedaan worden."

Het is lastig, dat in al deze Wetten de punctuatie zoowel als de bewoording zooveel te wenschen overlaten; het goed begrijpen en vatten van de bedoeling des wetgevers wordt er al te zeer door bemoeilijkt, en wordt de vertaling dikwijls bedenkelijk.

De Derde Wet is de Anggěr Agèng, "eene verordening van den Raden Adıpati Såsrå di Ning rat te Suråkartå en van den Raden Adipati Danurĕdjå te Ngajogyåkartå, in algeheele overeenstemming met al de Najåkå's te Suråkartå en Ngajogyă, en is goedgekeurd

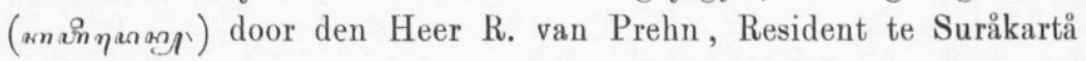
en den Majoor Ridder Mr. Huibert Gerard Nahuijs, Resident te Ngajogyå, als ook van den Pangeran Arijå Prabu Prang Wadănå, en grootvader Pangeran Arijå Paku, Alam. Wij zijn ter zake dezer wet allen tot overeenstemming gekomen op het kantoor in het fort te Klațèn op den $16^{\text {en }}$ October 1817." Voorts wordt de hoop uitgesproken, dat deze verordening in de beide rijken toegepast zal worden. ${ }^{2}$ Aan het slot dezer Inleiding wordt aangeteekend: "Gedaan te Suråkartå, op Maandag 14 Surå, Wawu, 1745" (= 15 October 1817 volgens O.) terwijl aan het slot dezer wet nog eens voorkomt: "Geschreven te Suråkartå op Zondag 3 Bĕsar, Wawu, 1745. Deze drie datums kloppen niet precies met elkaar. -

1 De heer O. schrijft mij, dat men tegenwoordig voor nasis meer $\eta$ mะ ถ⿱亠 K. Ng. gebruikt. Deel I. p. 19 r. 15 v. o. geeft hij het door „hoofden" terug. In Mr. L. W. C. v- d. Berg op. cit. p. 58 vindt men: „Het Openbaar Ministerie ter hoofdplaats (Ngajogyå) bestaat uit vijf bureaux (Kori), aan het hoofd van elk waarvan een Panewu Djaks̊̊ staat, onder wien een aantal Mantri's Djaksi̊ werkzaam zijn."

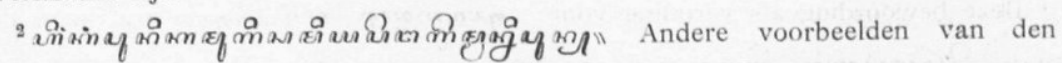
Conjuctief bij ભ ณ (verder door „Gramm." aangeduid) p. 182 , 
In Roorda's uitgave heeft deze wet 4,1 Artikelen, tegen 4.8 bij den heer $\mathrm{O}$.

De vinrde wet is de Nawiliu Pradiata Dalèm (Anqqür Pradialia Awal wel genoemd. O.) van den Susuhunan Paku Buwånå VII, voor den Wadånå-Djakså Among Pråjå te Suråkartå. De wet heeft aan het slot de dagteekening, 18 Bĕsar, Dal, $1759=20$ Mєi 1832, en heeft 42 Artikelen.

Aan het slot der Inleiding wordt gezegd, dat als iemand van Suråkartå een geschil heeft met iemand uit Ngajogyå, alléén die geschillen berecht mogen worden, welke ontstaan zijn na den tijd dat mijn Vader eene ontmoeting had met mijn Grootvader den Sultan te Djati Sari. Alle geschillen van vóór die ontmoeting mogen niet meer in behandeling komen. Hetzelfde gold voor de geschillen, tusschen iemand van Suråkartå met iemand uit het gebied van Mangku Nagårå, ontstaan vóór de samenkomst van deu Susuhunan en den Adipati Mangku Nagårå te Sålåtigå.

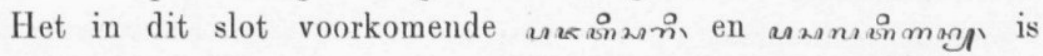
eene zelfde woordvorming als sniงung of a Patuh. Art. 4; Gramm. p. 156, $3^{\circ}$; en: Walbeehm, De Woorden

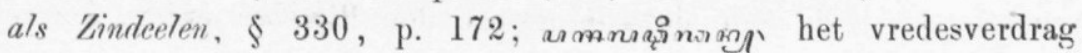
tusschen den Soesoehoenan en Mas Saïd tijdens eene reis naar

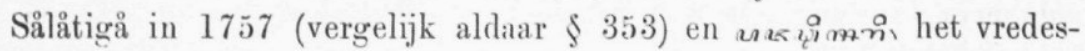
verdrag tusschen Pakoeboewånå IV en Mangkoeboemi te Djatisari in $1755 . "$ )

In Art. 1 wordt voorgeschreven, dat als een lid der vorstelijke familie, een lid van den rijksraad, bupati, kliwon of daarmee gelijkstaand persoon als aanklager in een rechtzaak optreedt, dan mag hij zelf niet verschijnen, maar heeft een gevolmachtigde met een verzegelden brief waarin zijn zaak omschreven wordt, te zenden. Zoo ook als een van hen gedaagde is in eenige zaak. En moet één van hen een eed afleggen, dan moet dit in zijne eigen woning geschieden. (De heer O. heeft hier iets anders.)

De viJfos wet is de Anggěr Gunung, van den Susuhunan Paku Buwånå VII, d.d. Maandag 15 Ruwah, Be, 1768=23 September 1840; en heeft 102 Artikelen.

De heer O. teekent hierbij aan: "Deze Anggĕr is uitsluitend voor het Rijk van Solo gemaakt doch wordt in Jogja ook geraadpleegd. Zij schrijft in het algemeen voor, de verplichtingen der Goenoeng's ten aanzien van de toepassing der voorschriften van 
de Anggēr Sapoeloeh. Ten einde de uitgave van dit werk niet noodeloos kostbaarder te maken, zijn hier (namel. in de Vertaling) slechts die artikelen opgenomen, die voor landhuurders van eenig belang ziju." - De belangstellende Lezer kan den volledigen $\mathrm{J}_{\mathbf{\Delta} \mathbf{v}}$. tekst in deze Uitgave vinden, Deel II p. 188 v.v.

Een Gunung is de titel van magistraatspersonen buiten de hoofdplaats, belast met het bestuur van een district of regentschap. In ran den Berg, op. cit. p. 57 wordt gezegd, dat de Regenten in de verschillende afdeelingen van het Mangkoe-nagårå'sche gebied den titel voeren van Wadånå Goenoeng.

De zesue wet is de Angger Sapulul. Een datum wordt van deze Wet niet opgegeven. In de "Inleiding" wordt gezegd, dat zij van den Rijksbestierder te Suråkartå is, in overeenstemming met alle inlandsche hoofdambtenaren, goedgekeurd door den Resident R. van Prehn, ${ }^{1}$ en door den Pangeran Arijå Prabu Prang Wadånå, overeenkomstig de opdracht van den Susuhunan; zij is bestemd voor de rechtspraak op "de paseban Bale Mangu Kapatijan," door de "prijaji Mantri Sadåså." Deze wet heeft dus haar naam ontleend aan deze tien rechtsprekende ambtenaren, die zitting houden in de paṇạåå vóór de woning van den Rijksbestierder, die zelf Lid en Voorzitter van deze rechtbank is. - Bij Art. 12 teekent de heer O. aan: "Mantri Sapoeloeh of Sadåså zijn de hulpofficieren van Justitie, die aan den officier van Justitie, den Djaksa, zijn toegevoegd. - Een der hoofdregenten alhier verklaart den oorsprong van den naam als volgt: "Iedere Najåkå (hoofdregent) had vroeger tien Mantri's, waarvan één werd gekozen, om den Djaksa als hulpofficier van Justitie bij te staan voor zaken onder het ressort van den hoofdregent, van wieu hij Mantri was." Het woord "sapoeloeh" zou dan hier moeten beteekenen: uit de tien gekozen. Oorspronkelijk zouden er dus zooveel Mantri's Sapoeloeh moeten geweest zijn als het aantal hoofdregenten, doch nu is het getal aangegroeid en worden zij direct tot die betrekking benoemd."

Wij zullen overigens niet langer stilstaan bij deze oudere wetten. Voor de Uitgaven en Literatuur noemen wij nog: Winler, Rechtspleging in Soerukarta. - C. P. K. Winkel, Essai sur les principes regissant l'administration de la Justice etc. 1880 , p. $66-76$. - R.

1 Als men weet, dat de heer R. van Prehn van 1817-1820 Resident te Surakartå is geweest, moet de samenstelling dezer wet ook in deze jaren gesteld worden; ongeveer gelijktijdig met de Anggěr Agĕng. 
de T. Bousquet, in Nederl. Jaarboeken noor Rechtsgeleerdheid en Wetgeving, V. $1^{\mathrm{e}}$ stuk. - D. L. Mounier, Vertaling enz. van de Nawala Pradata awal. Batavia 1844. - Regt in N.-I. I. p. 327. - A. C. Vreede, Catalogus v. d. Jar e. Marl. Handschriften der Leidsche Bibliotheek p. 358 vv., waar nog een "Anggĕr Glaḍag" genoemd wordt.

Het $3^{\mathrm{e}}$ deel, Javaansche tekst, heeft de heer O. in 5 hoofdstukken verdeeld, inhoudende allerlei Pranatan's, Model-Piagĕm's enz., respect. $28,9,12,31$ en $14=94$ stuks bevattende. Eene inhoudsopgave vóór het werk doet die allen kennen.

Slechts van de sub 1 bedoelde 28 Pranatan enz. vindt men in het $1^{\mathrm{e}}$ deel de Hollandsche vertaling. De inhoud van de 4 volgende hoofdstukken werd wel door den heer Oudemans vertaald, en het Handschrift naar de drukkerij verzonden, maar dit ging, onbegrijpelijker wijze, verloren. Is dit voor den schrijver eene groote teleurstelling, zeker ook voor de Lezers van zijn werk voor wie deze vertaling in de eerste plaats bestemd was. Laat ons hopen, dat de heer O. later tijd en gelegenheid zal hebben, dit deel van zijn arbeid nog in het licht te zenden.

Voor den beofenaar van het Javaansch levert deze Jav. tekst wel geen aangename lectuur, maar geeft toch aanleiding genoeg, met al zijne taal-eigenaardigheden, tot het maken van taalkundige aanteekeningen, ten bate van Lexicon en Grammatica. Men heeft daarbij te bedenken, dat dit werk niet behoort tot de "hooge literatuur"; maar deze Wetten en Verordeningen toch werden op schrift gebracht door mannen, die tot de meest ontwikkelde en beschaafde Javanen behoorden, levende in kringen en onder invloeden die hen zelfs onbewust hunne taal als die in hun kring levende deden schrijven. Dat deze teksten toch nog zooveel te wenschen overlaten, hebben wij zeker voor een groot deel aan afschrijvers te danken. $\mathrm{W}_{\text {ij }}$ wezen er boven reeds op. En als men nu op Java buiten de Vorstenlanden leveude, reeds met allerlei bezwaren voor eene meer wetenschappelijke bewerking dezer wetten zou te worstelen hebben, hoeveel te meer moet dit hier in Nederland het geval zijn, waar men om zoo te zeggen geheel aan zich zelf is overgelaten, verre verwijderd van het land waar deze stukken thuis behooren. Het zijn dan ook slechts enkele aanteekeningen, die wij hier willen laten volgen over eene nog al bekende verordening, namelijk de Pranutan Patuh. Wij laten den Javaanschen tekst hieronder volgen, met de mededeeling dat men eene vertaling 


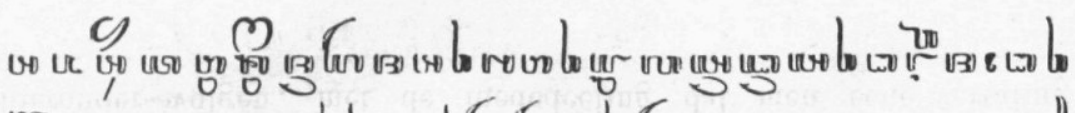

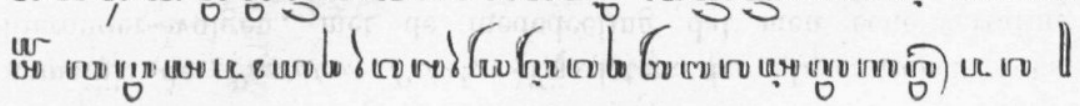

$$
\text { -I }
$$

\section{Sicurbusour}

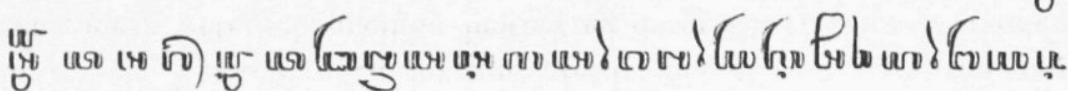
16 o

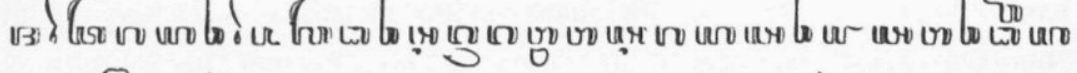

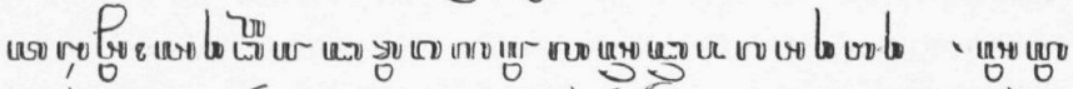

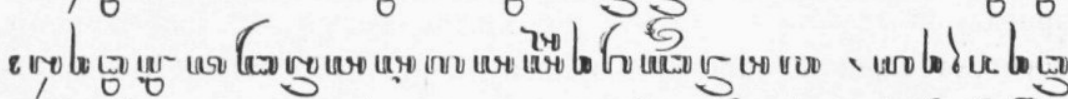
ט

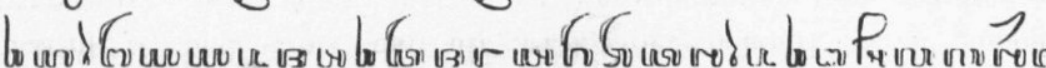

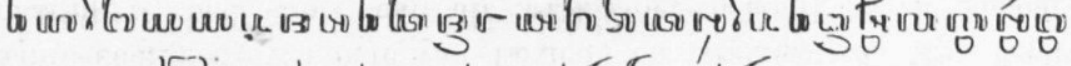

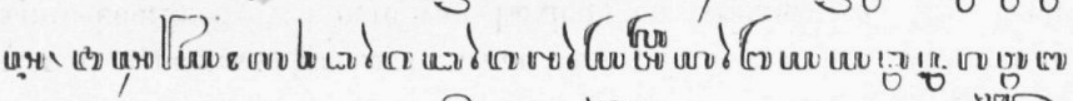

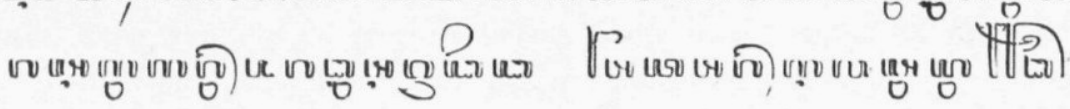

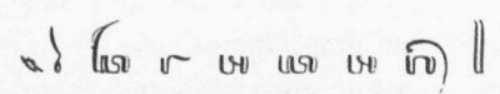

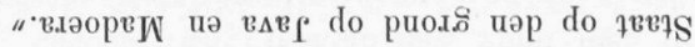

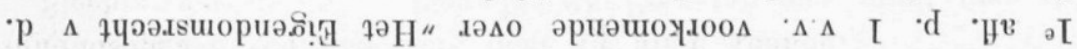

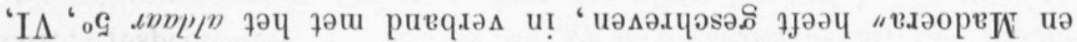

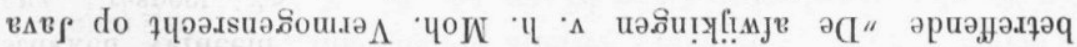

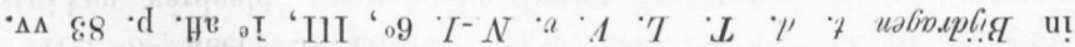

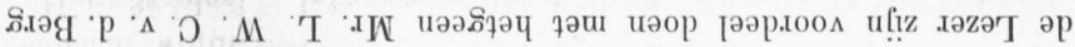

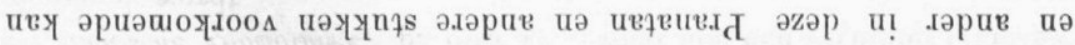

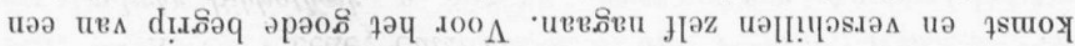

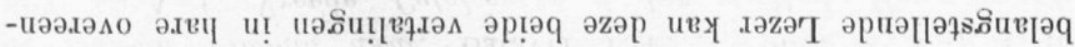

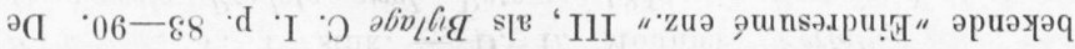

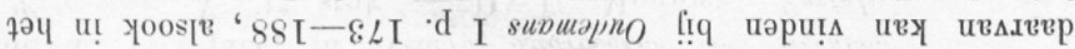




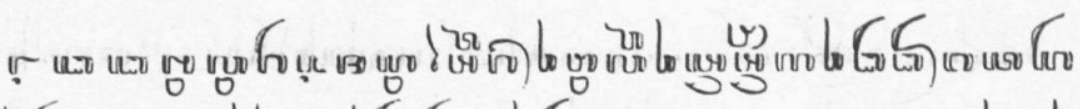

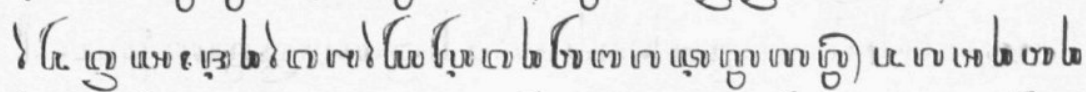

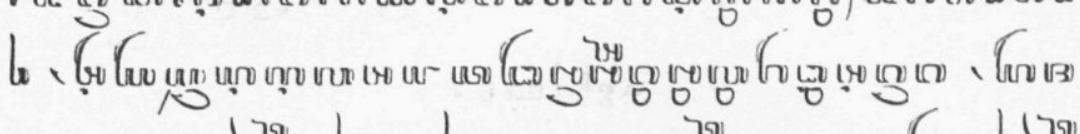

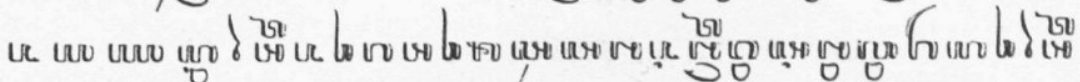

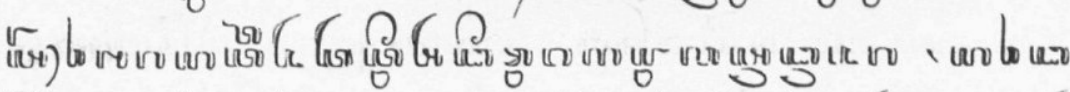

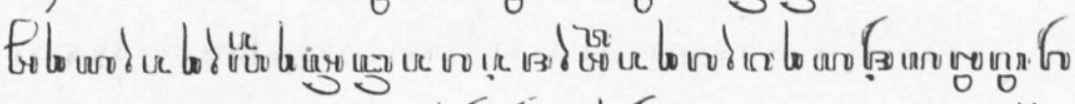

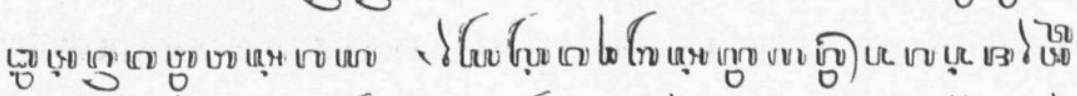

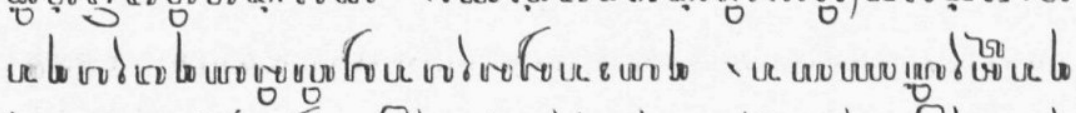

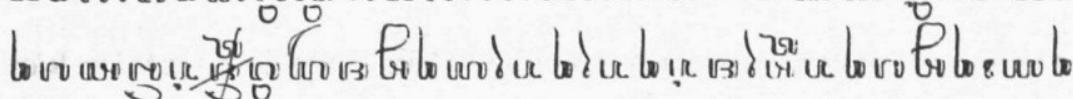

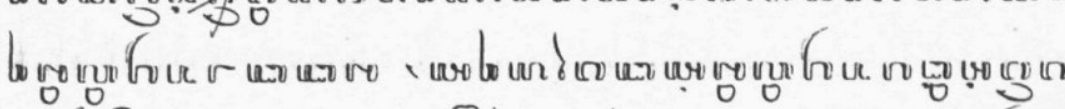

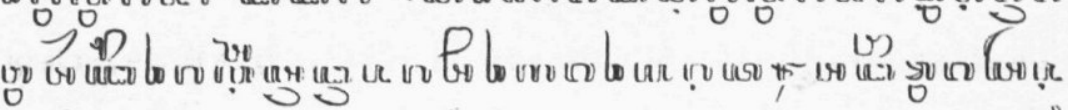

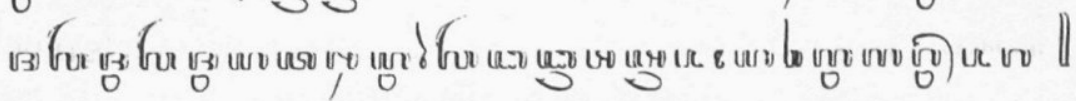

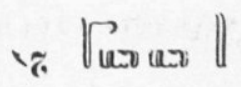

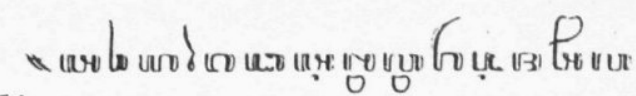

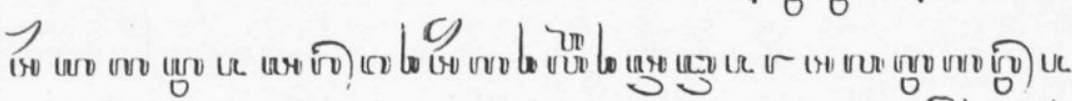

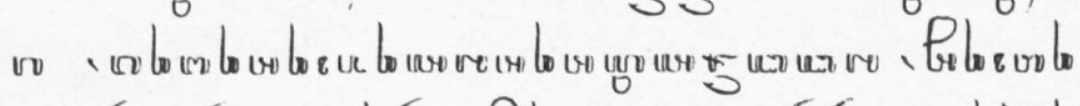

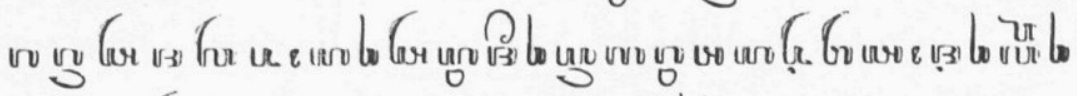

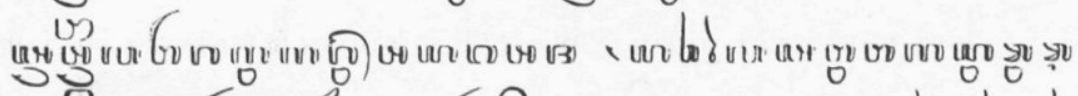

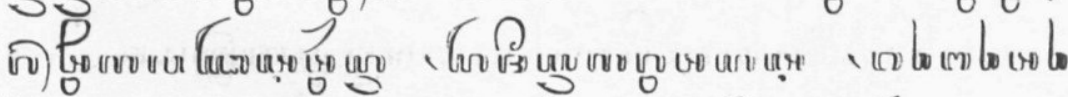

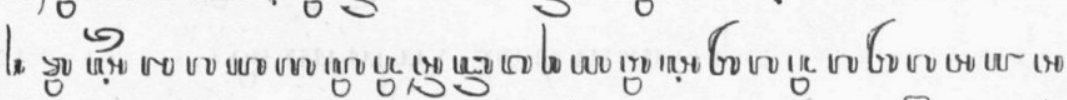

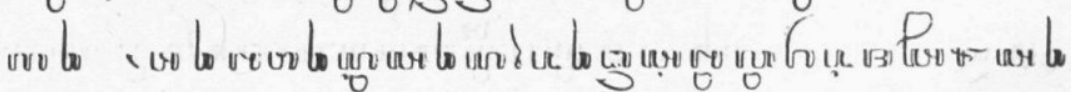

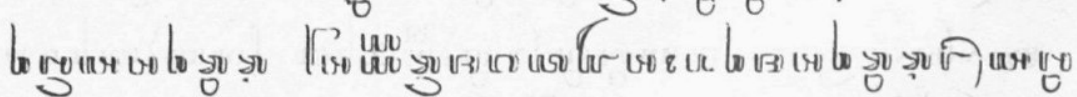

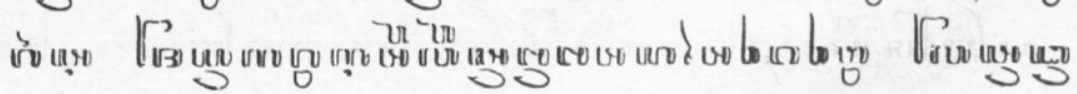




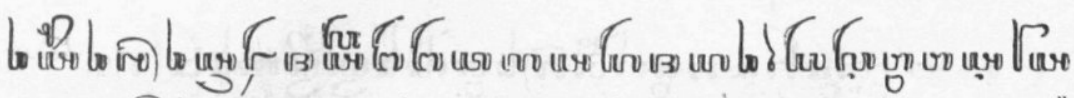

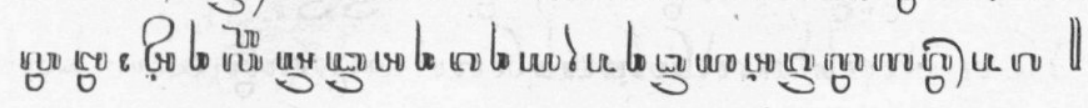

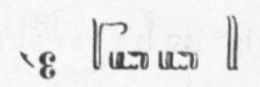

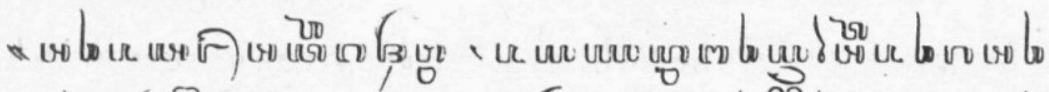
veroberar la

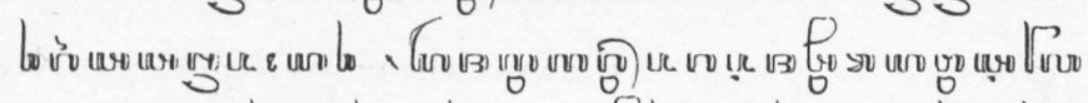

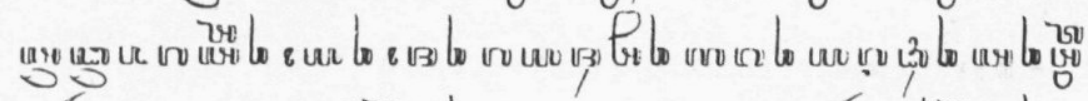

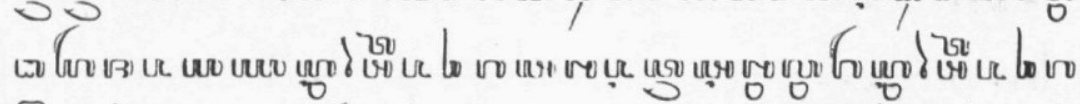

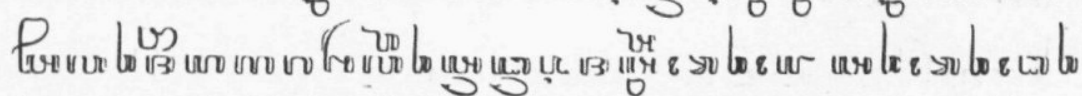

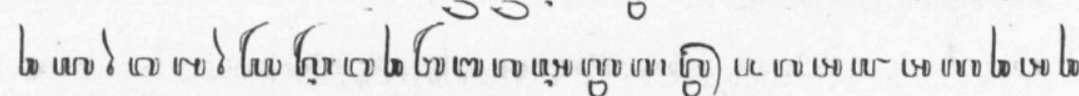

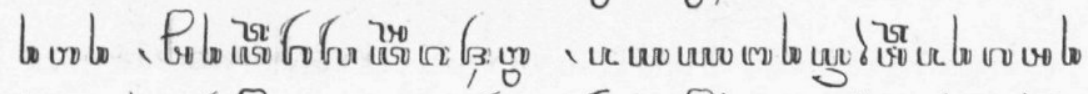

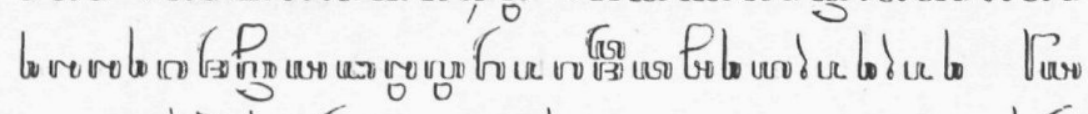

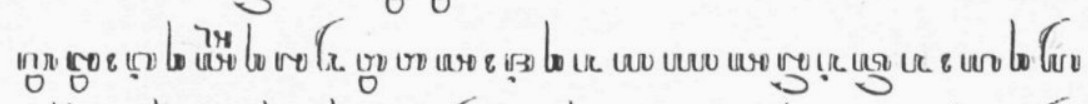

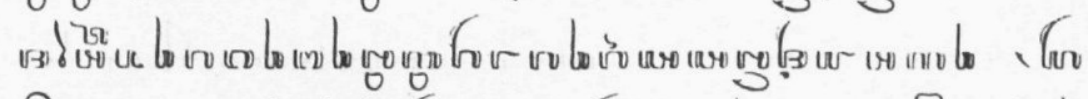

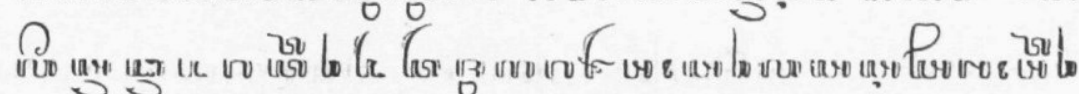

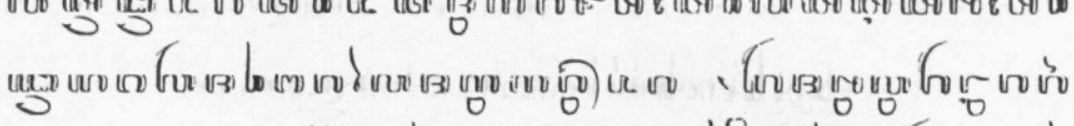

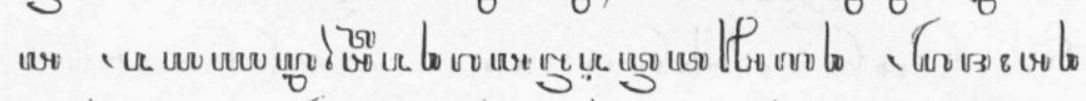

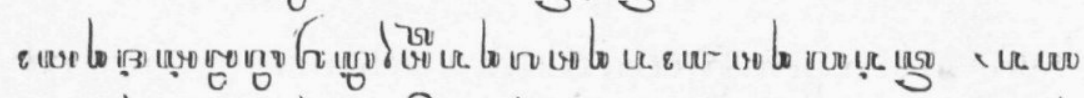

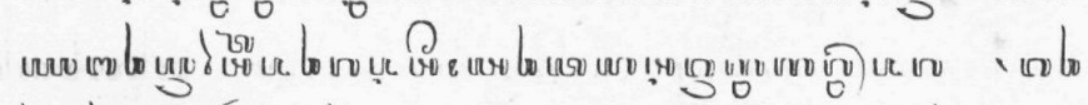

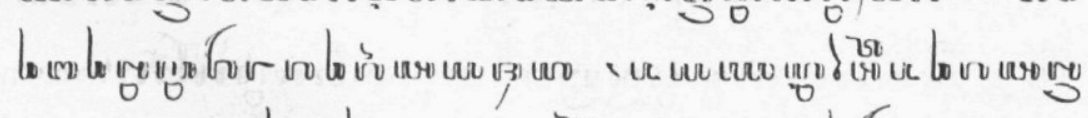

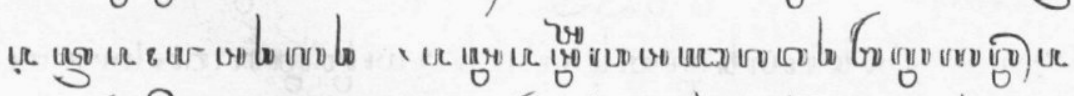

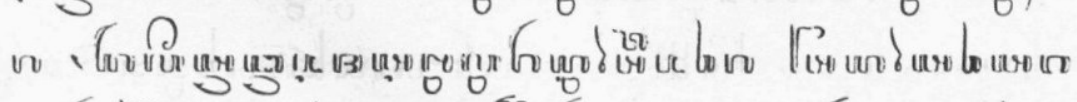

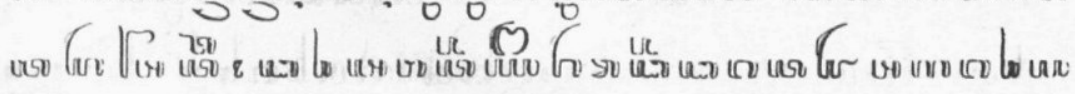


ๆ ๆ

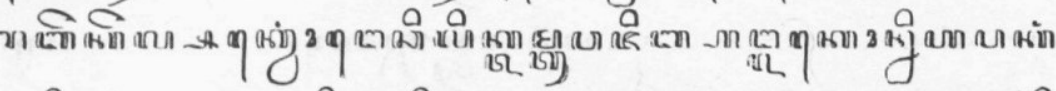

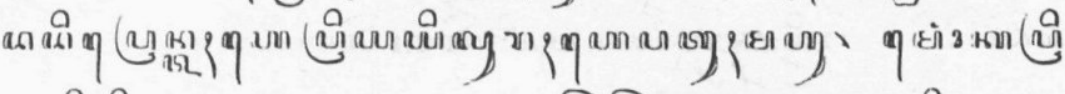

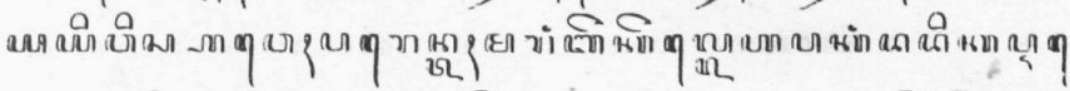

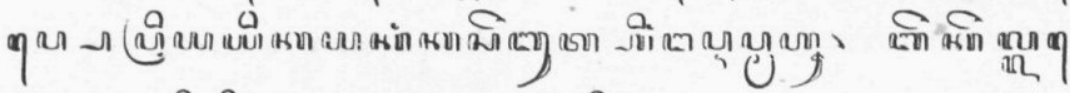

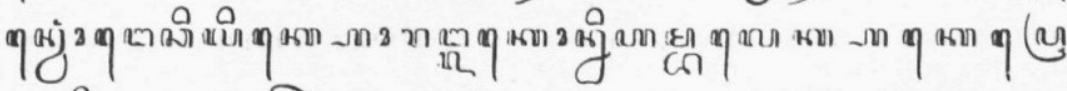

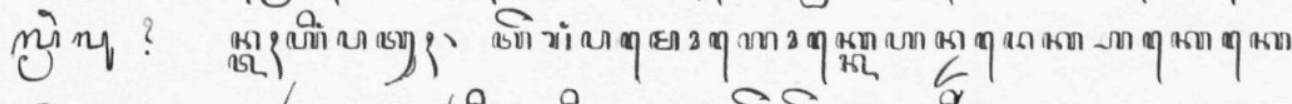

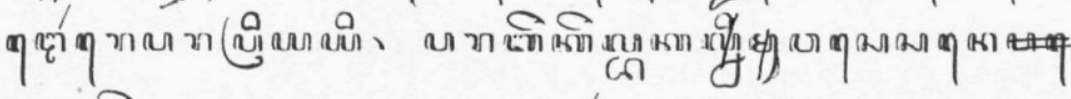

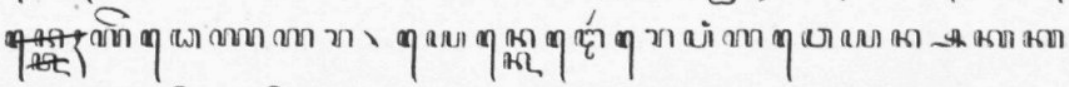

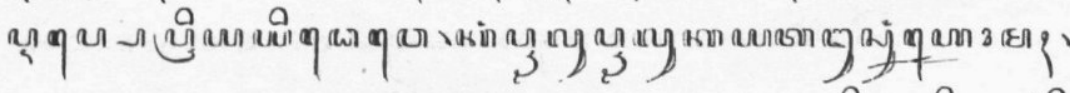

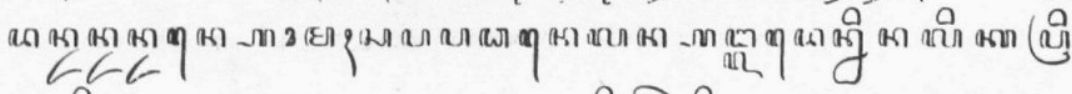

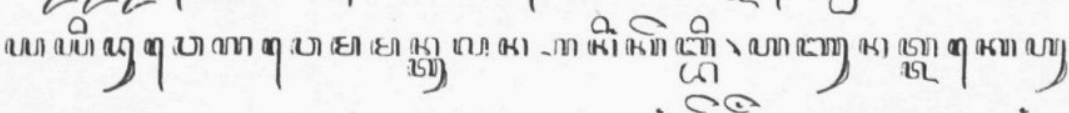

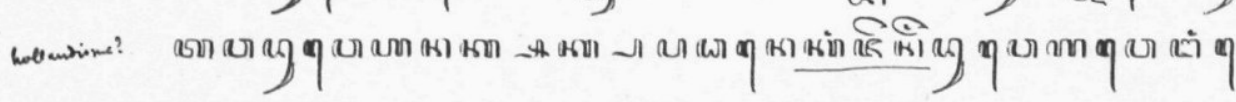

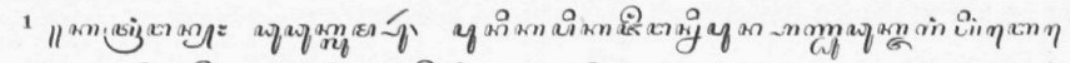

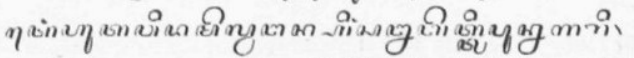

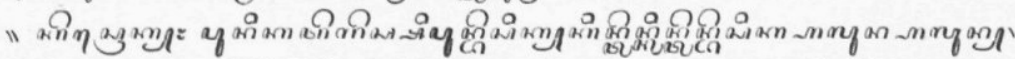

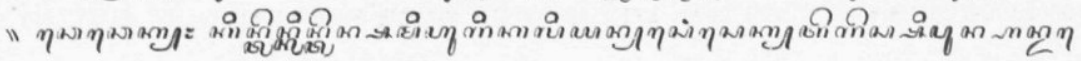

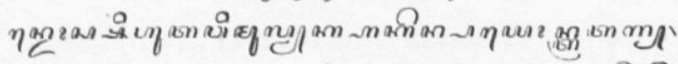

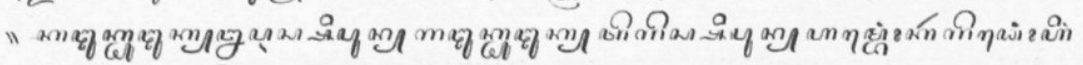

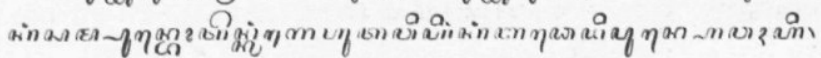

" ๆ भi

"

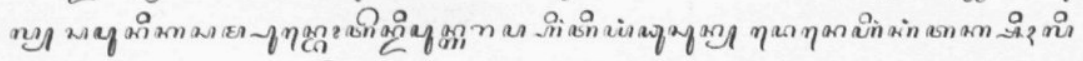

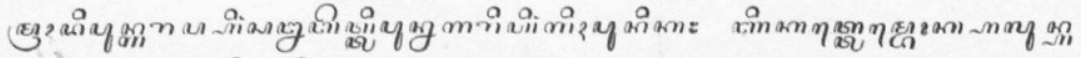

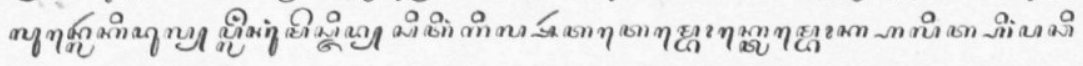
क⿻⿰丿亅八阝 


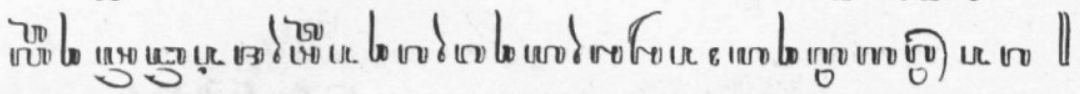

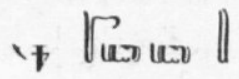

\section{arrobiso)}

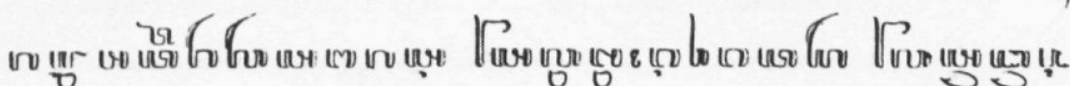

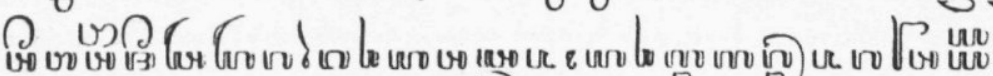

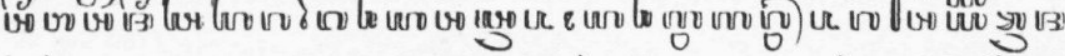

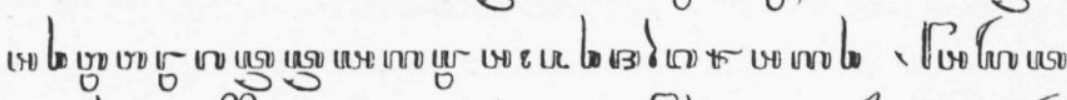

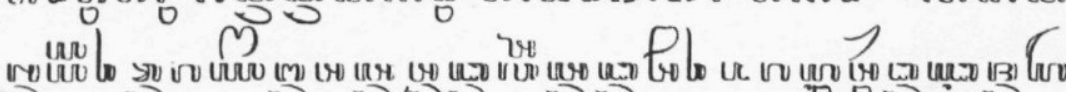

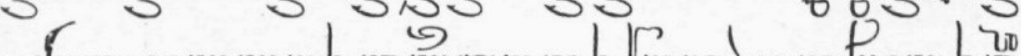

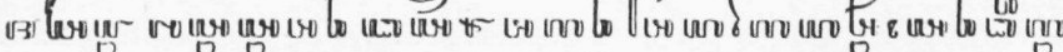

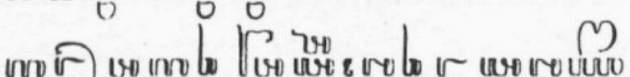

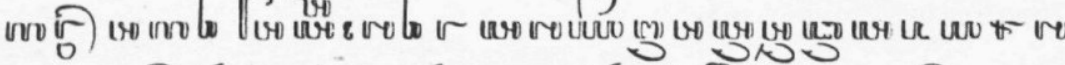
然然

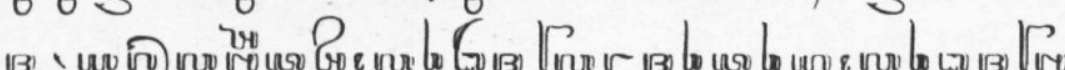

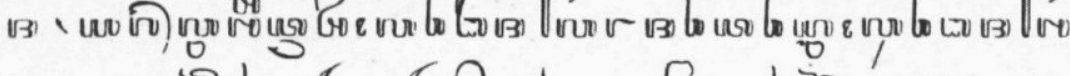

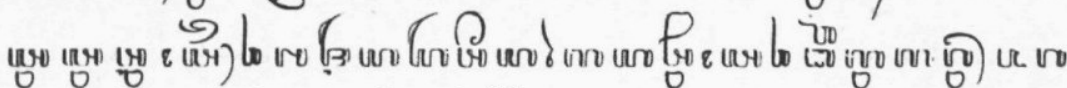

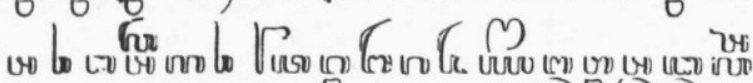

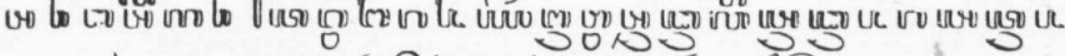

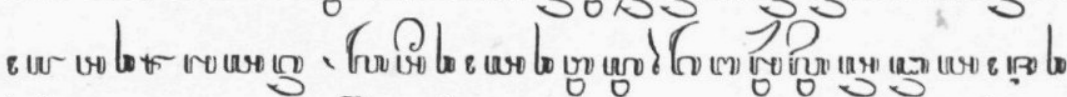

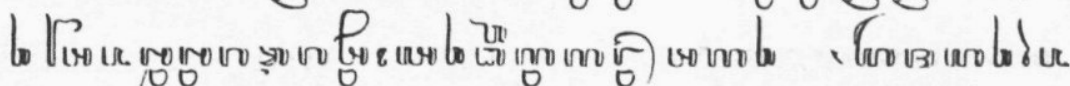

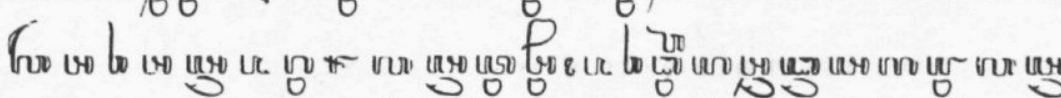

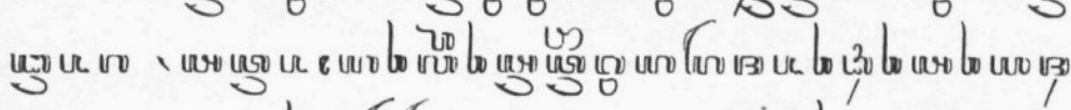

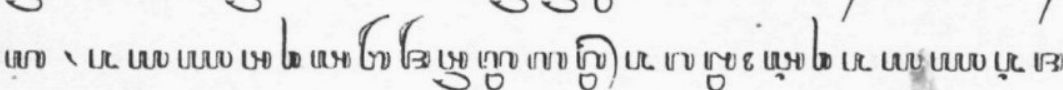
Ta

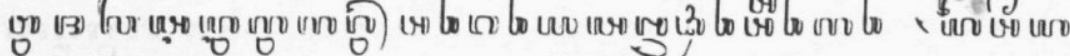

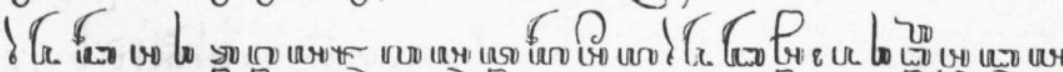

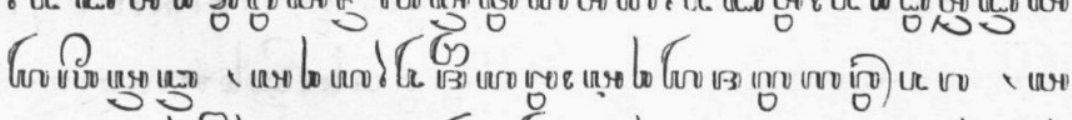

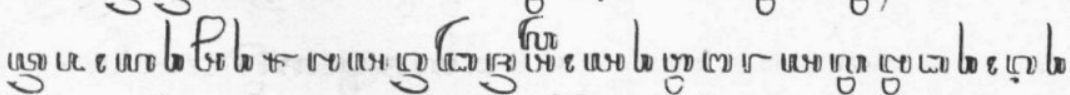

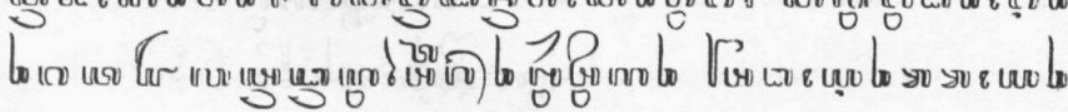




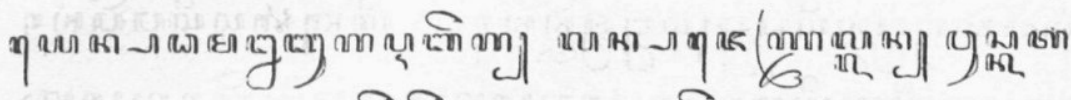
ๆ ซู ๆ

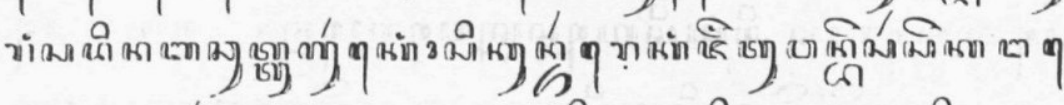

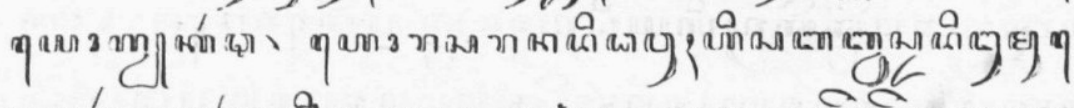

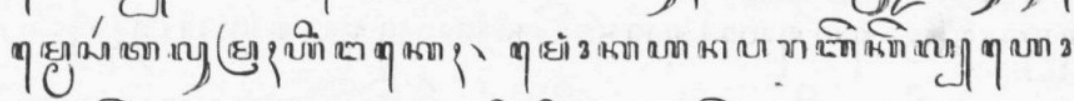

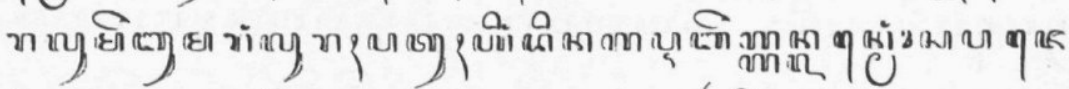

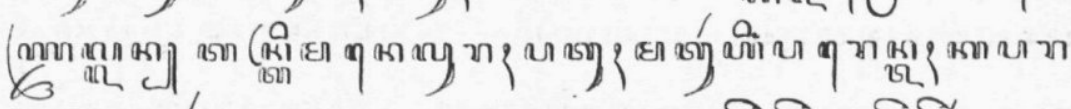

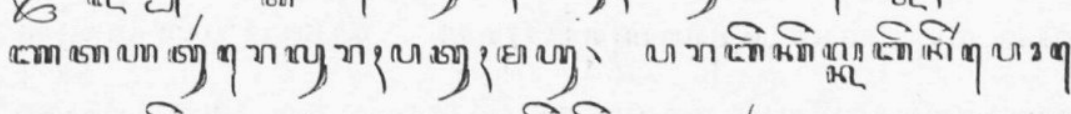
ๆ

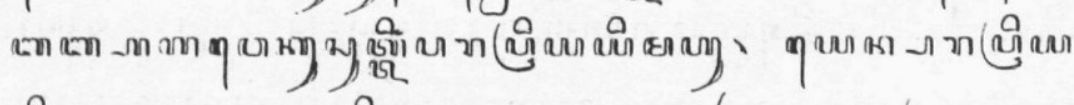

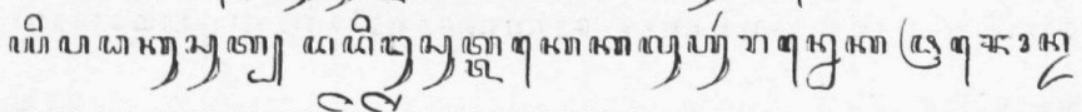

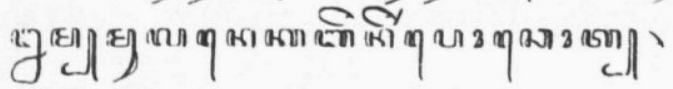

$$
\| \begin{gathered}
\operatorname{com} \operatorname{con} \\
c
\end{gathered} \mid
$$

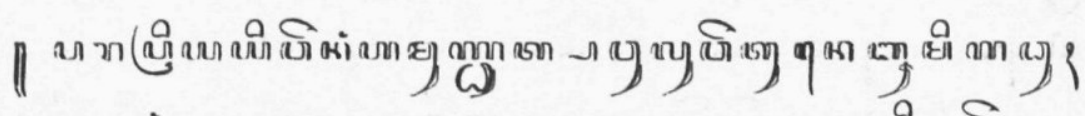

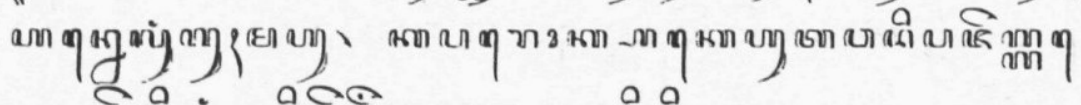

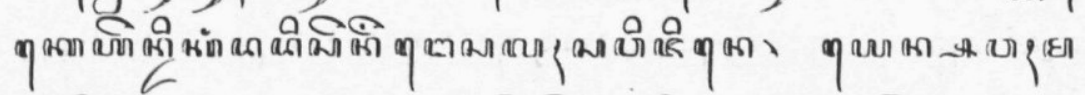

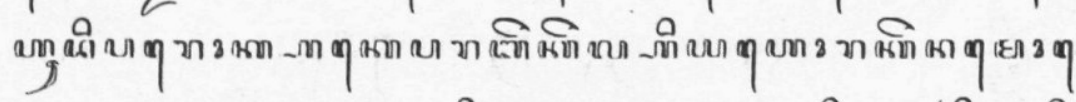

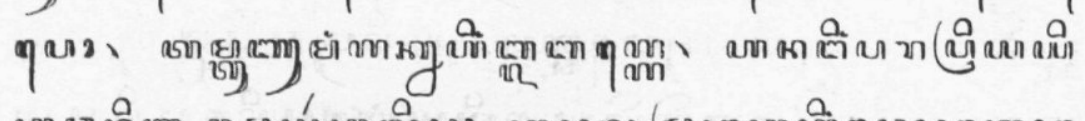

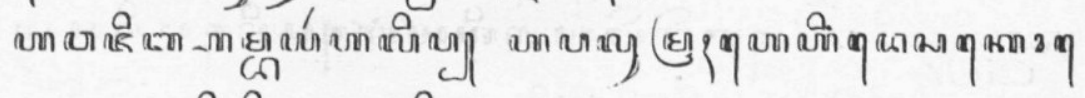

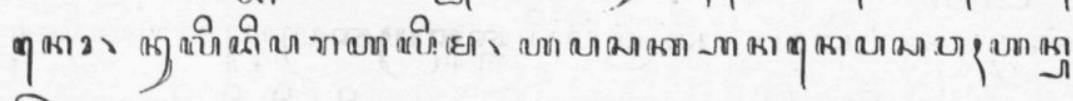

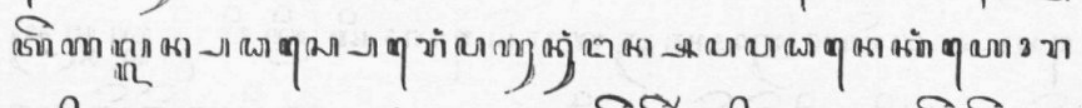
वूลิ ๆ 


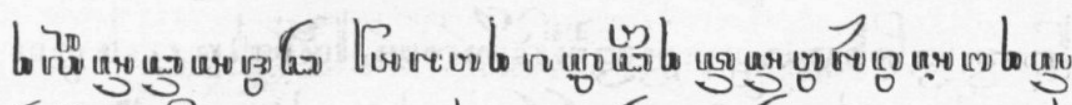

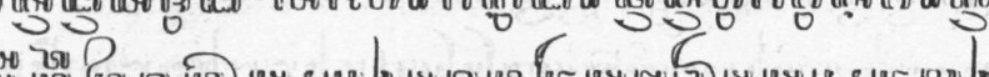

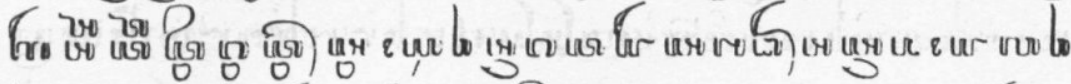

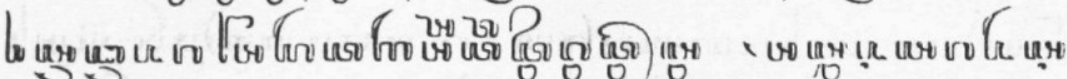
C) 100

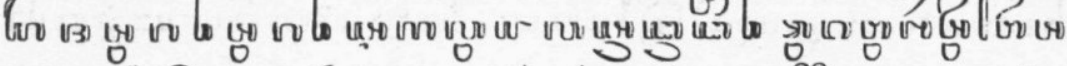

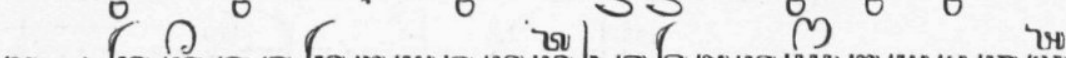

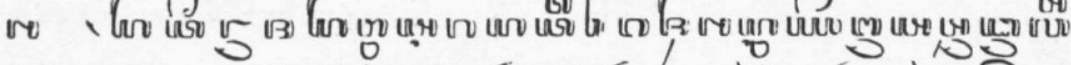

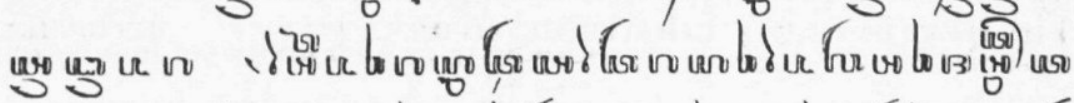

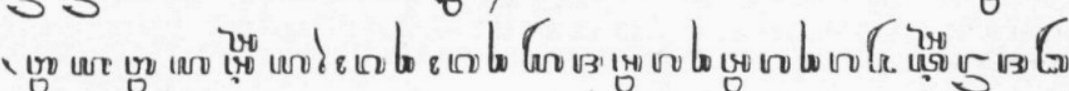

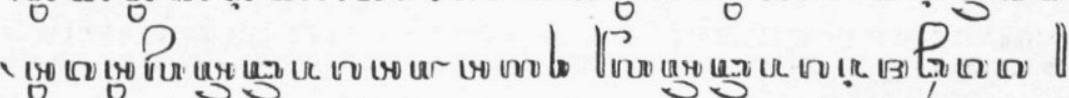
0 o ga

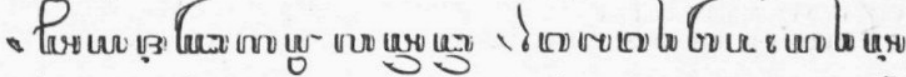

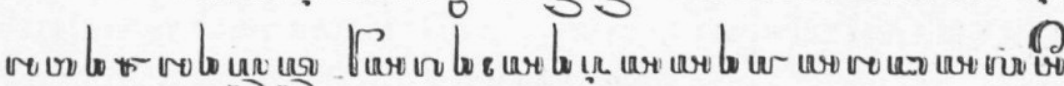

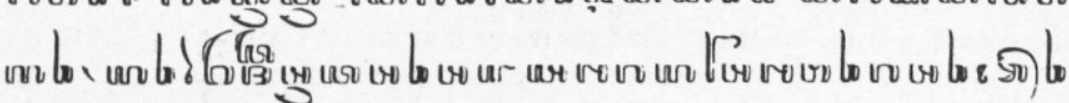

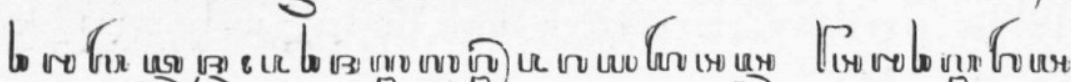

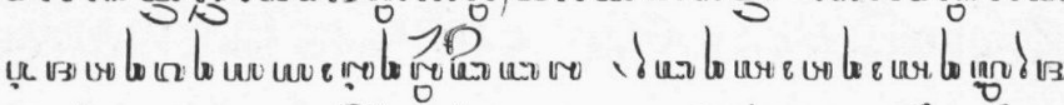

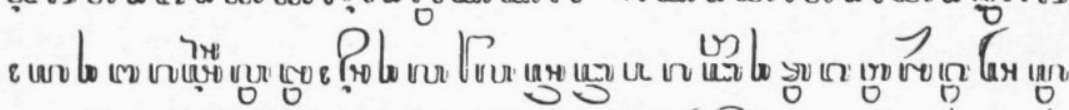

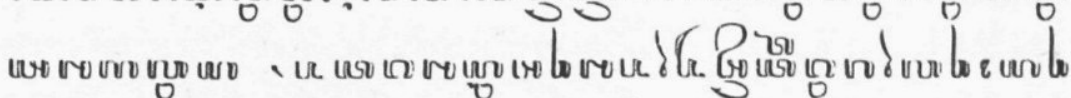

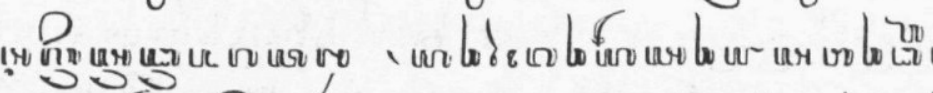
- I

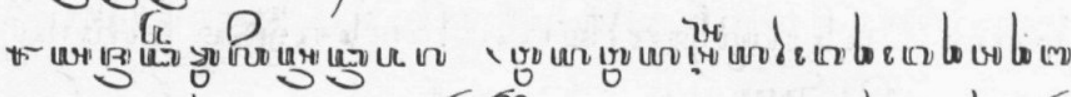

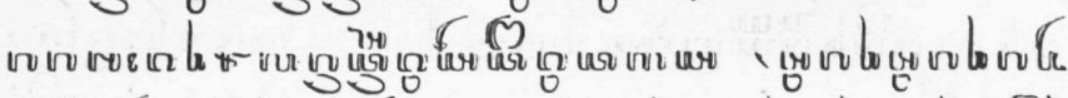

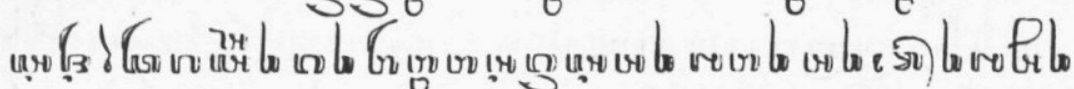

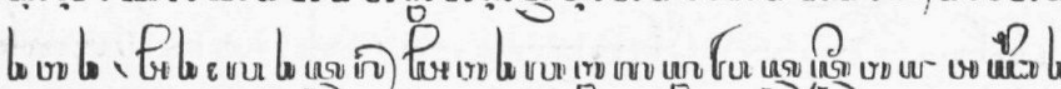

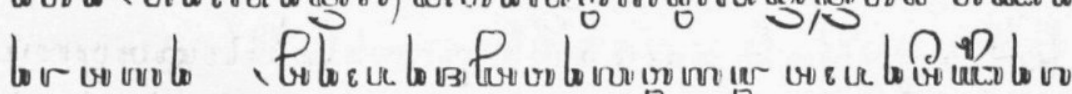

? C

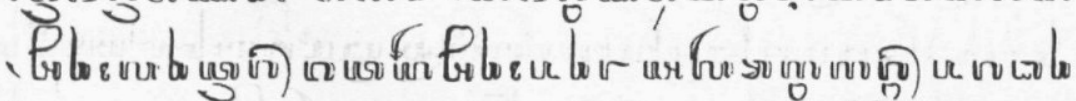
LPP 9 Pि

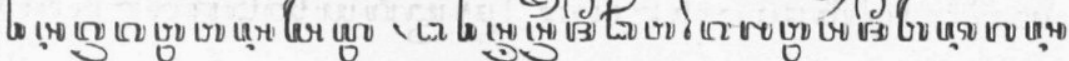




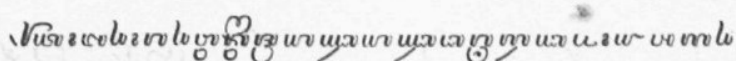

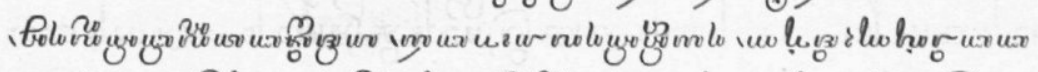

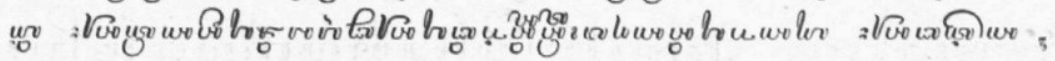

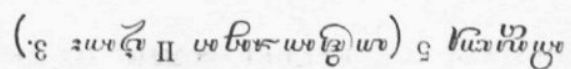

Uु

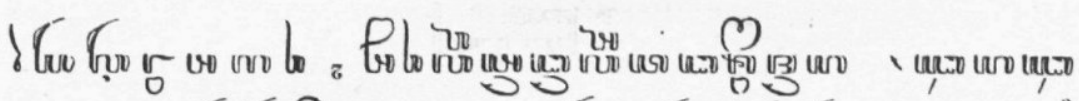

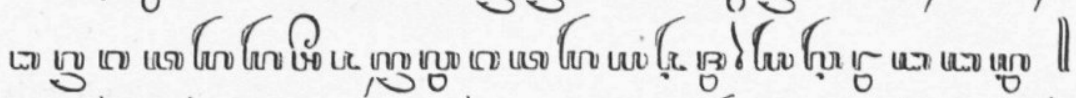

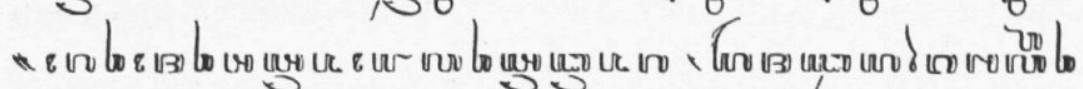

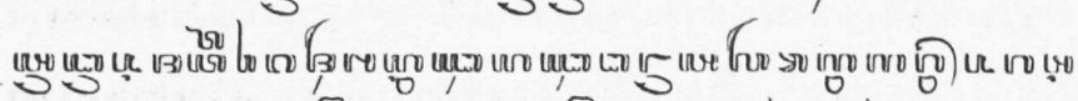

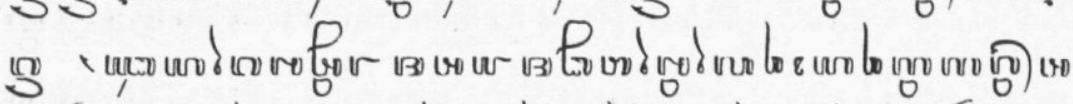

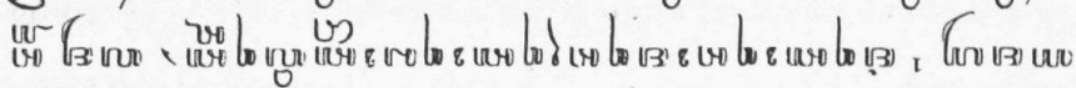

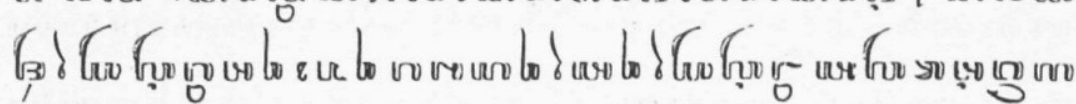

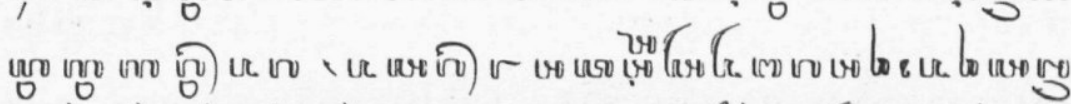

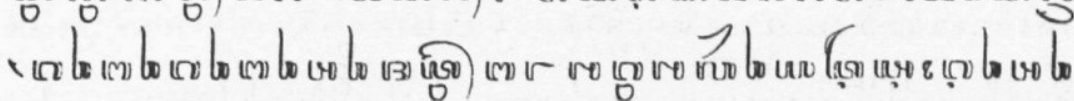

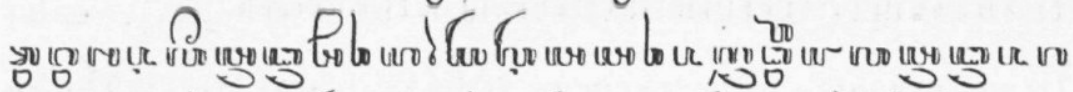

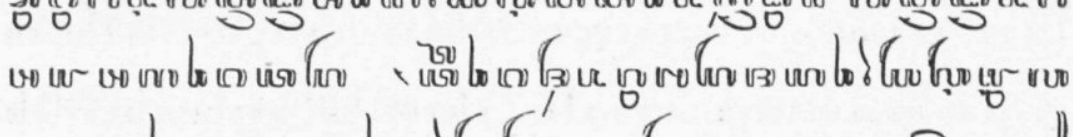

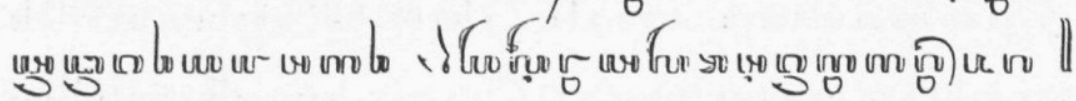
$9 \operatorname{Fin}_{\operatorname{lan}} \|$

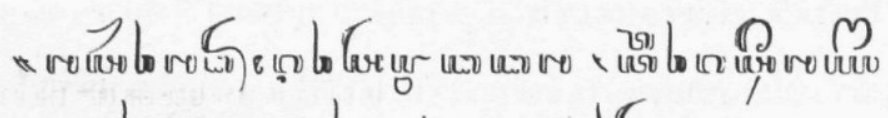

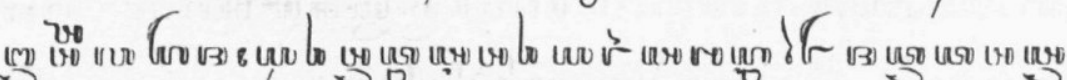
3.

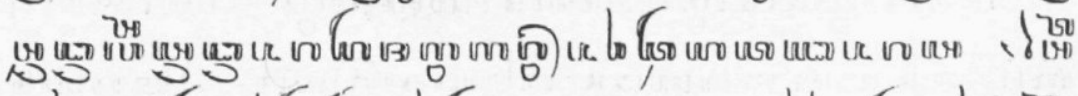

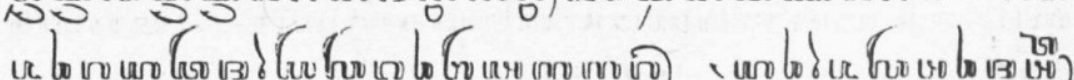

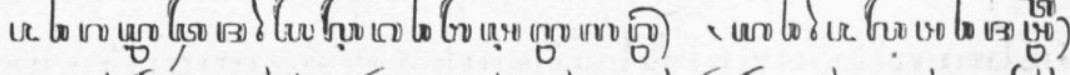

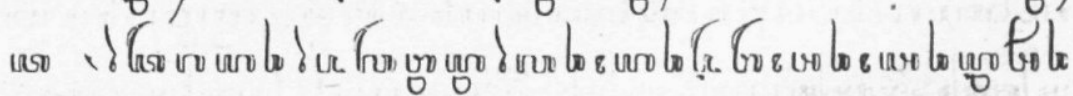




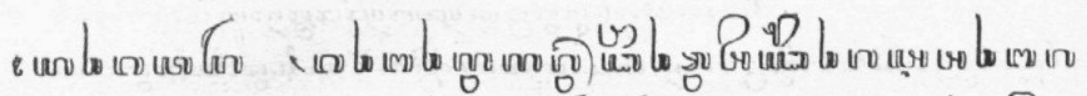

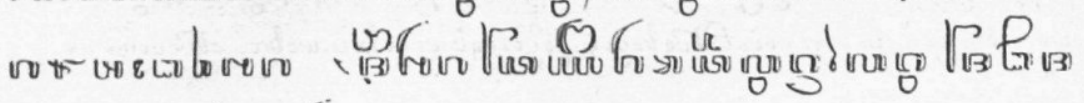

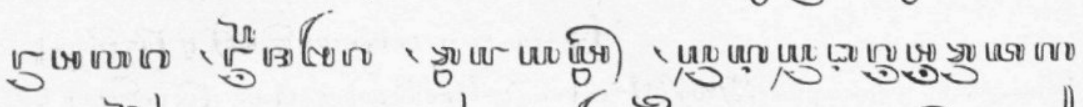

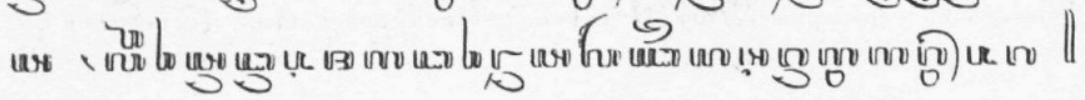

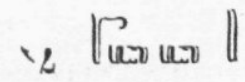

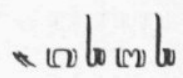

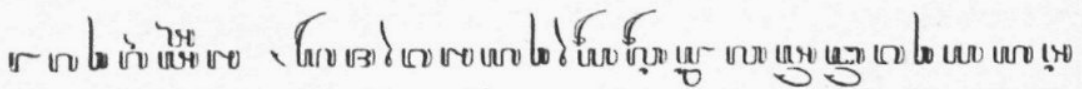

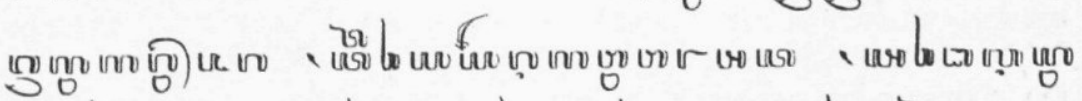

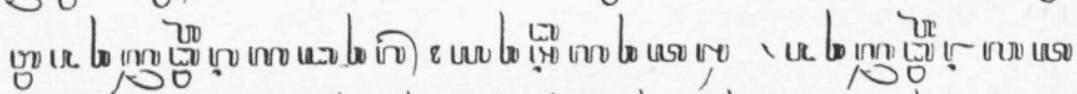

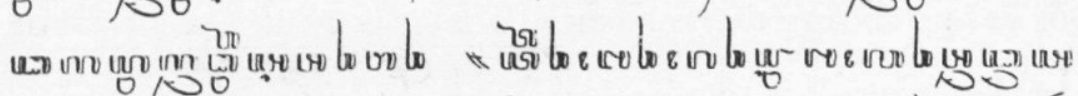

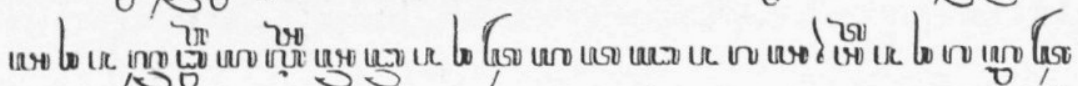
I א

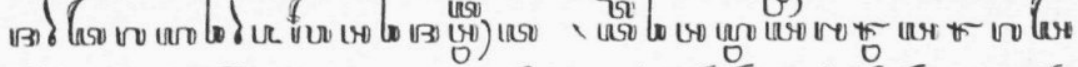

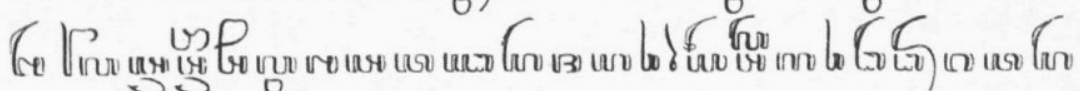

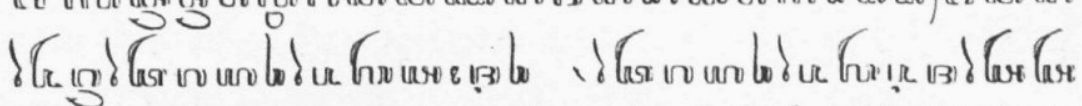

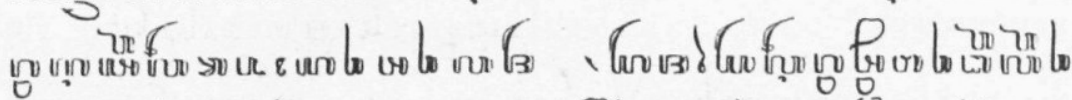

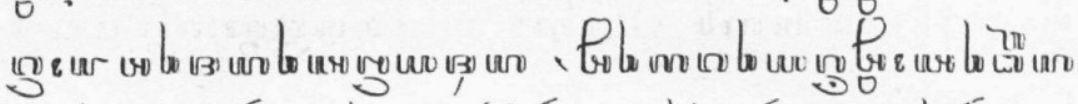

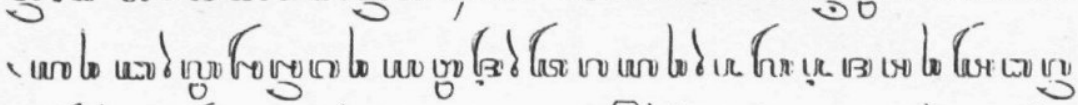
7 )

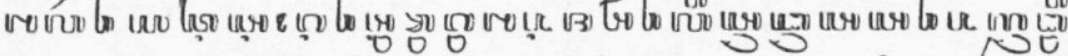

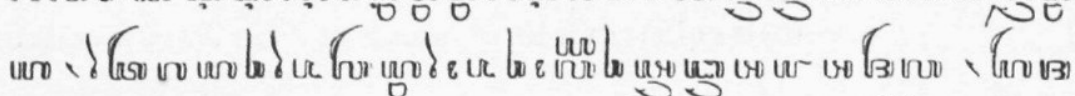
留

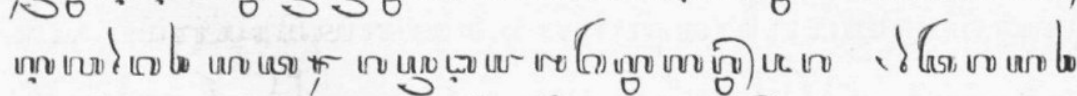

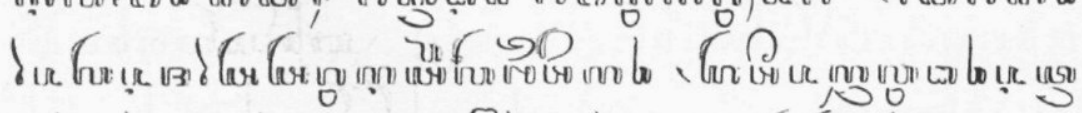

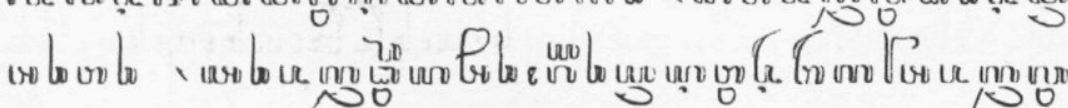




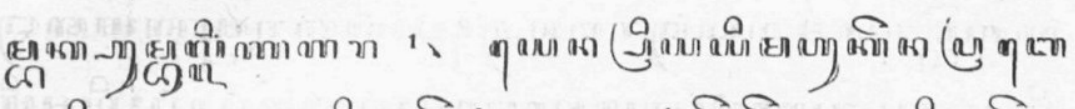

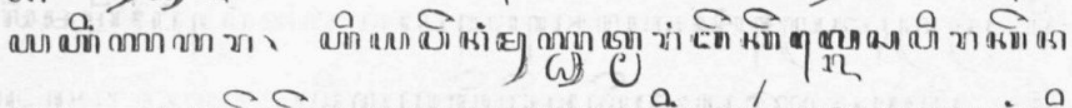

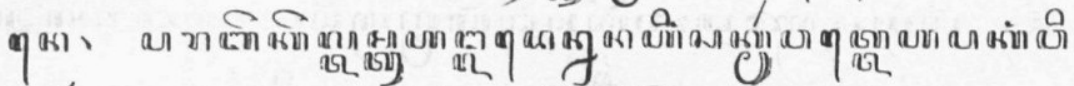
व

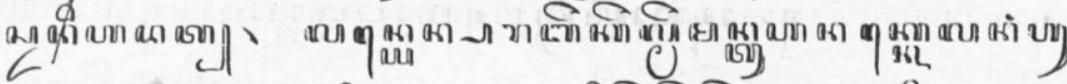

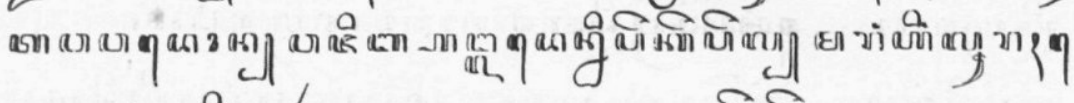
ๆ ๆ

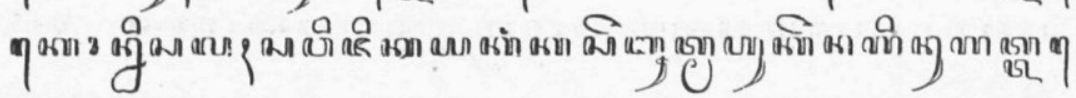

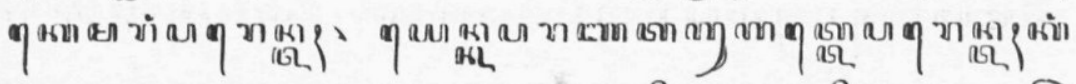

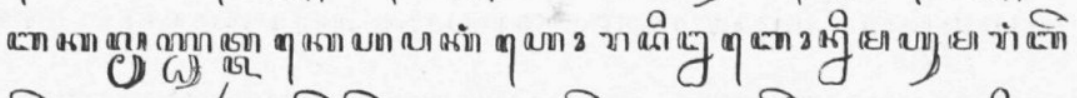

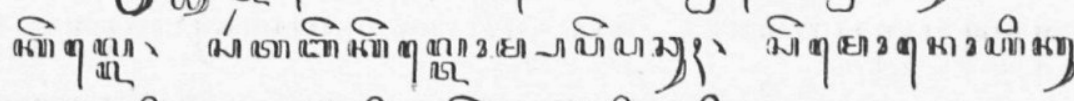

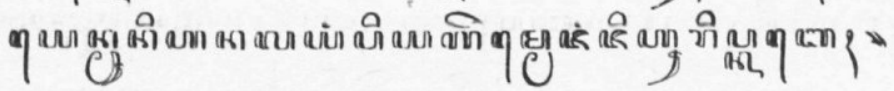

$$
\| \operatorname{amn} n \operatorname{ann} \mid
$$

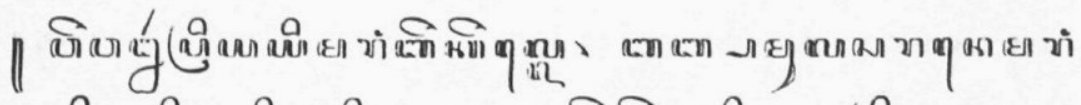

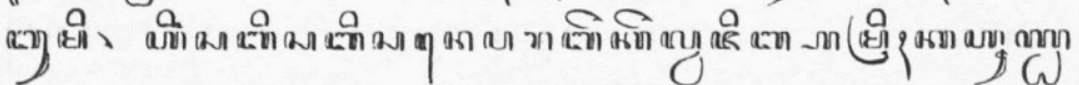

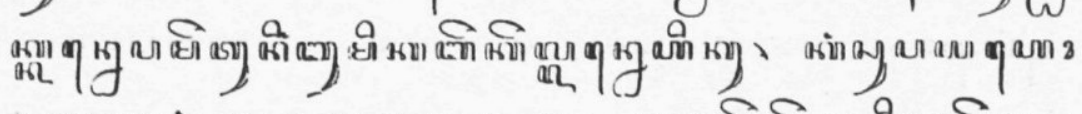

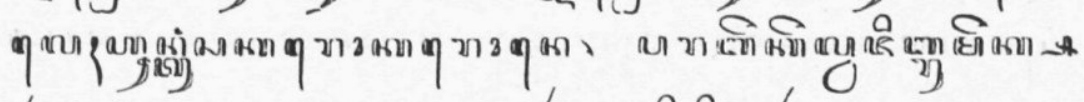

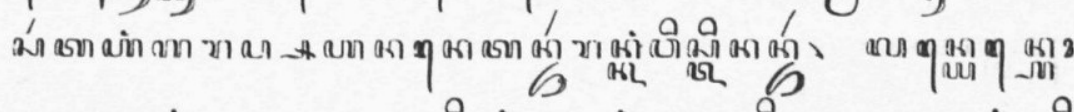

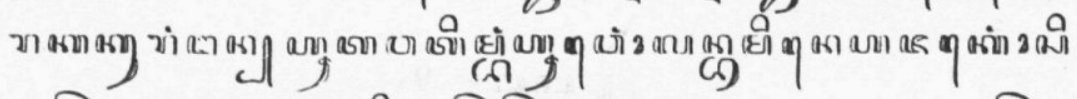

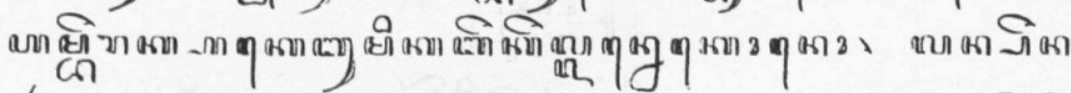

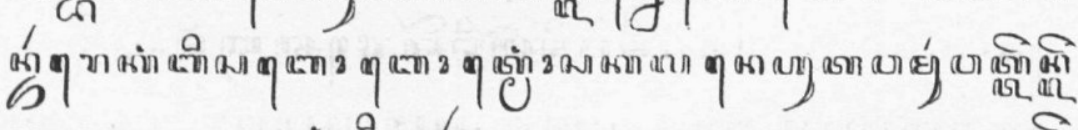

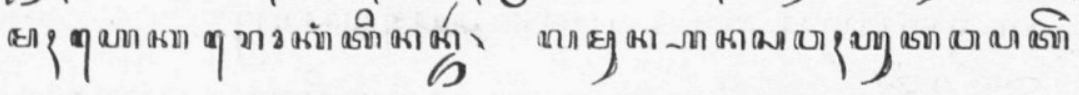

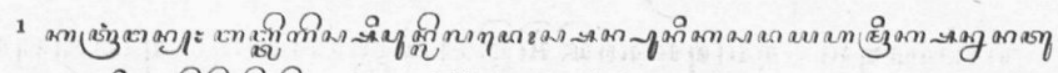

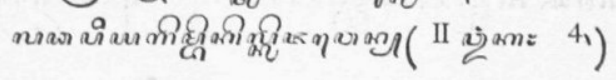




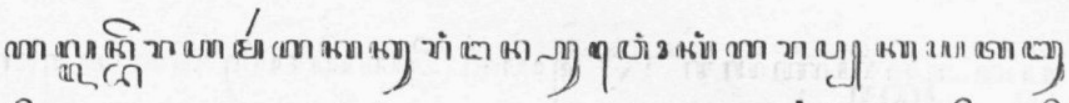

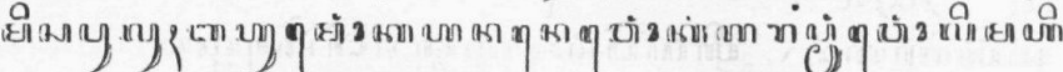
a a o co C O

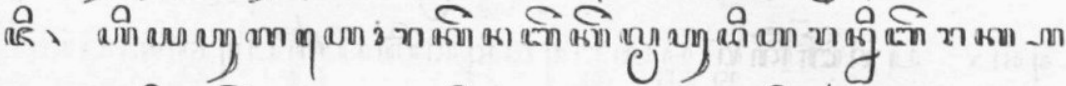

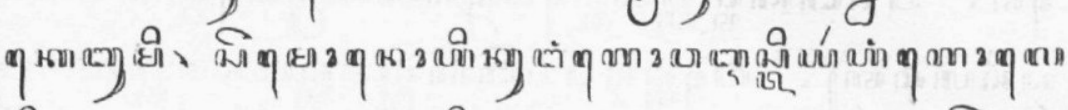

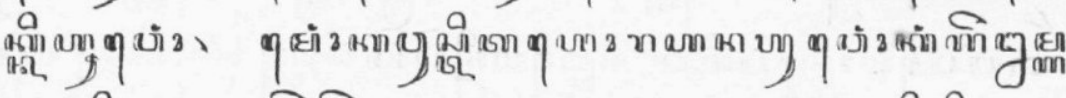

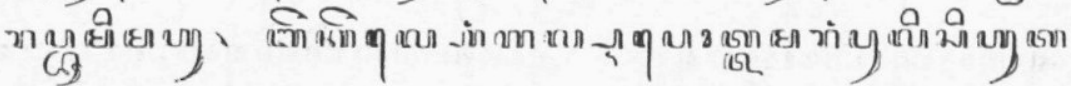

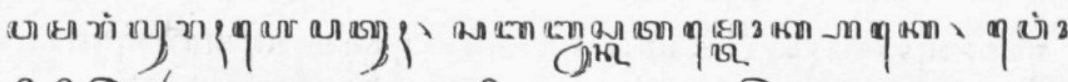

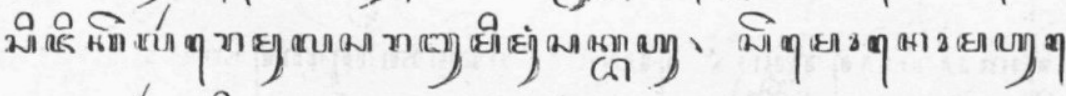

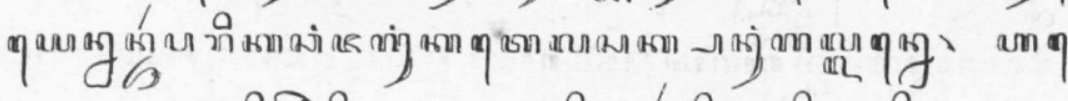

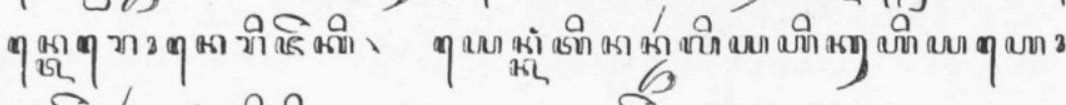

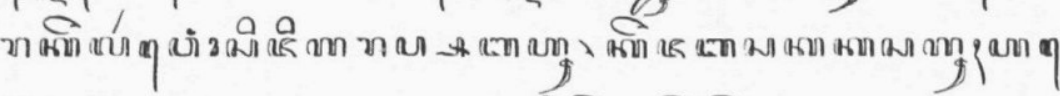

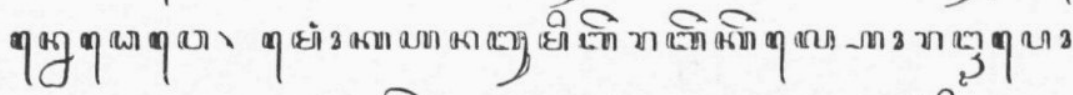

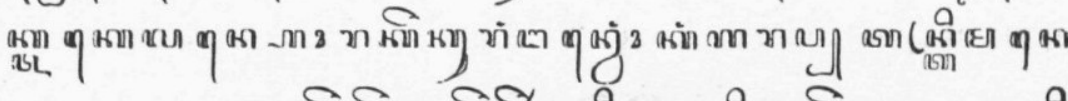

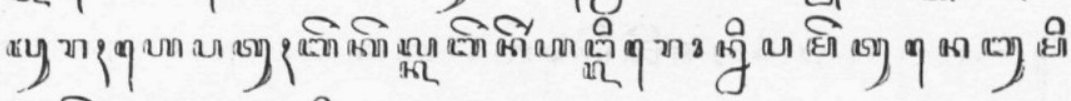

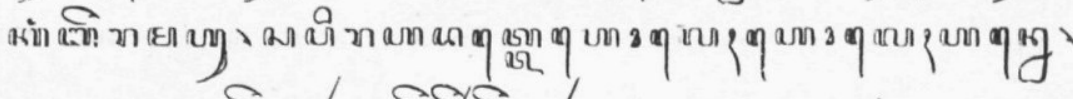

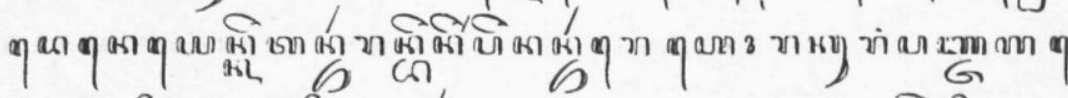

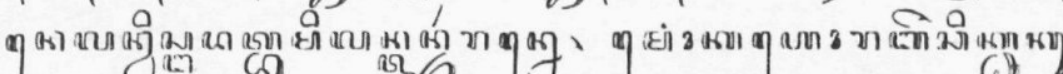

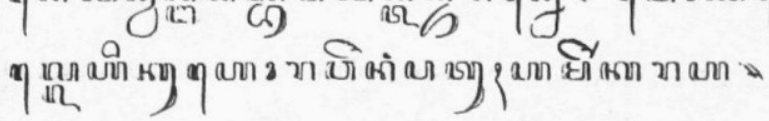

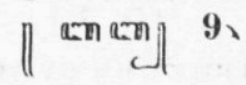

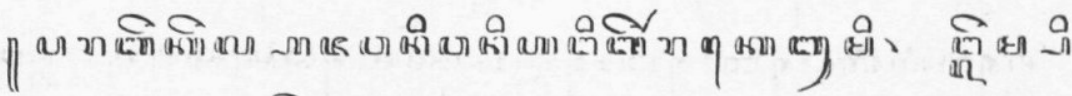

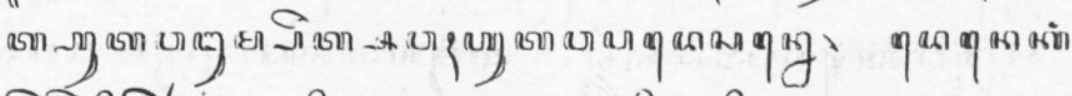

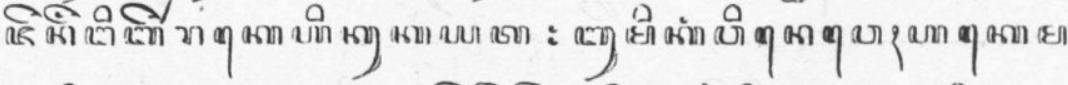

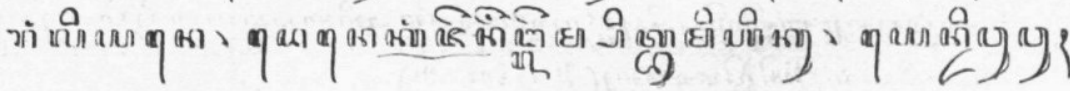




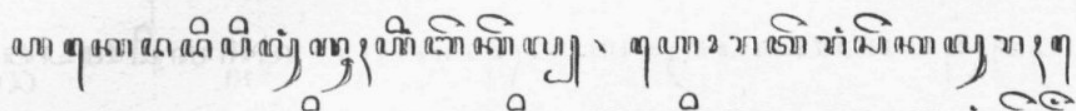
ๆ

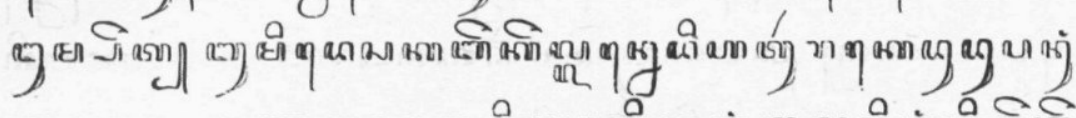

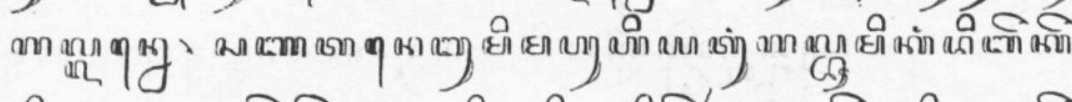

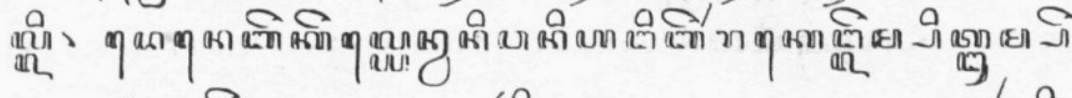

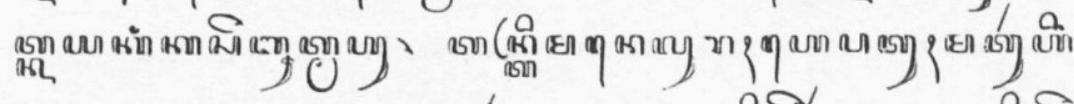

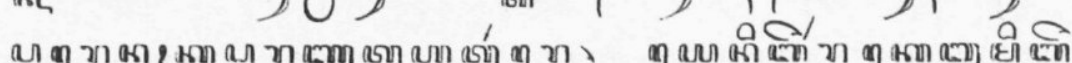

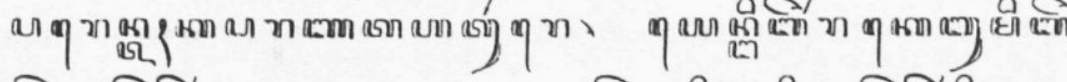

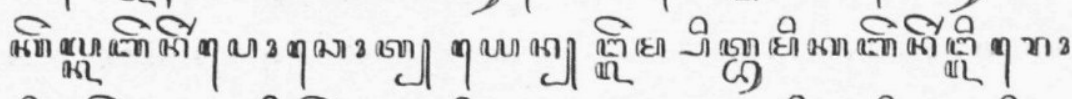

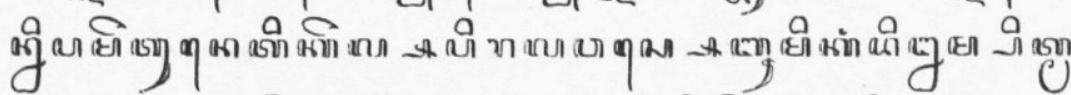

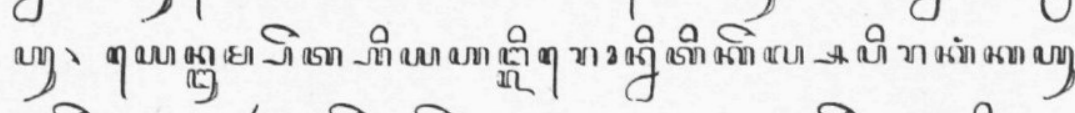

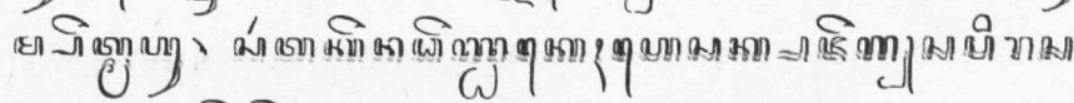

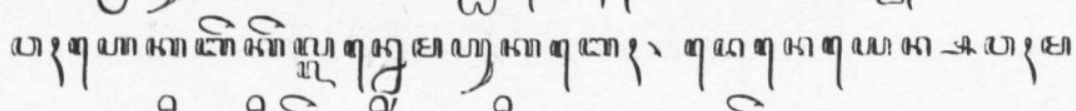
ๆ ग

$$
\|\operatorname{axn} a \operatorname{con}\| 10
$$

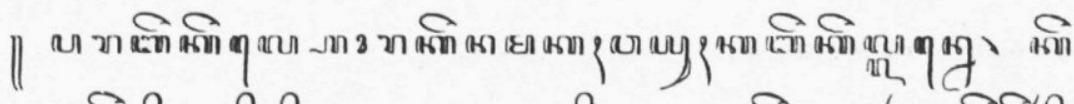

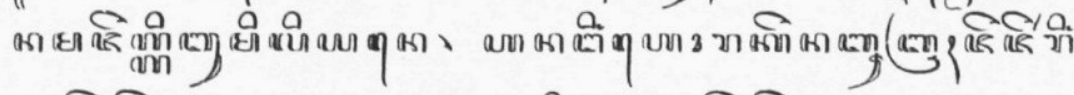

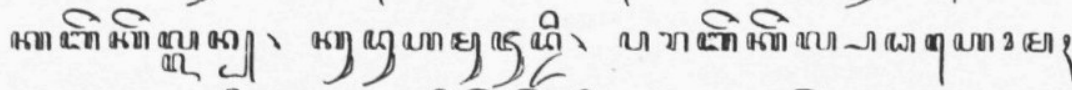

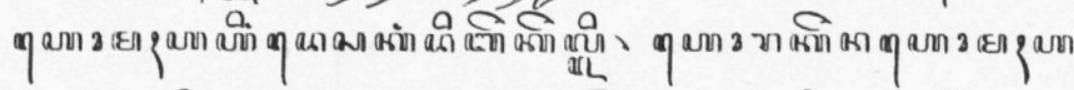

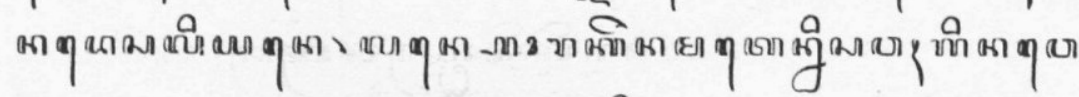

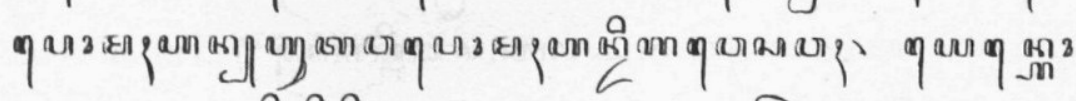

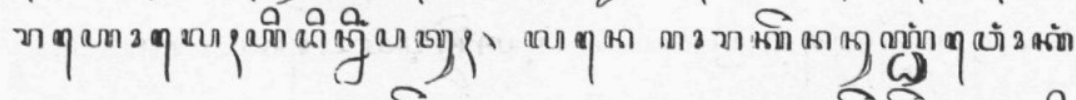

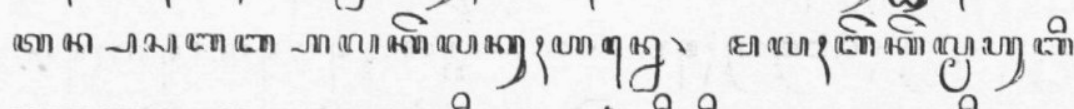

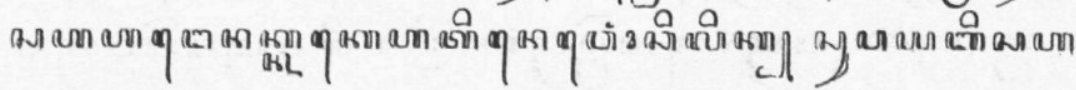




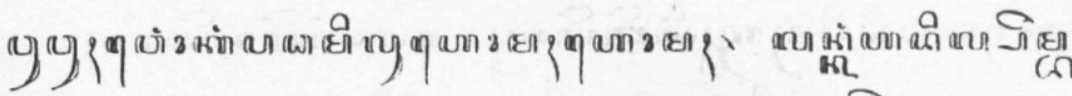

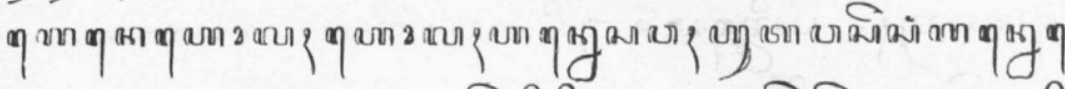
ๆ ๆ

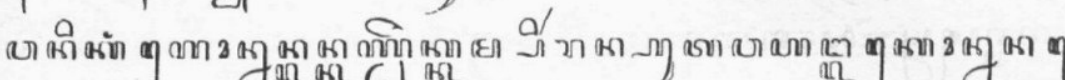

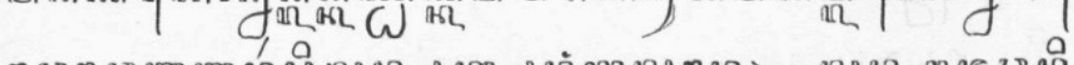

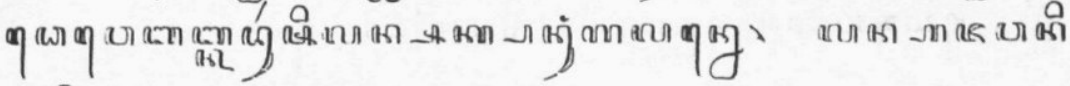

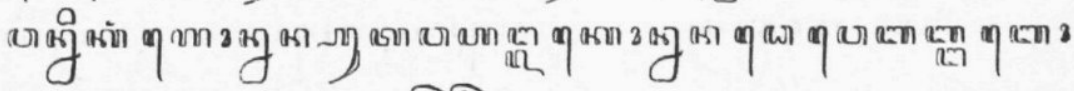

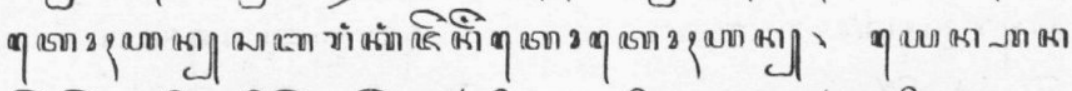

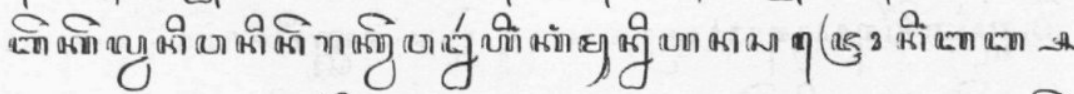

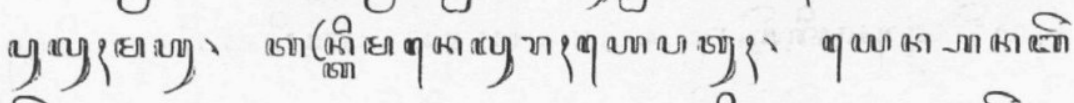

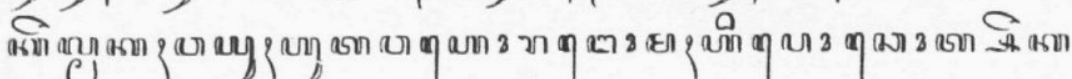

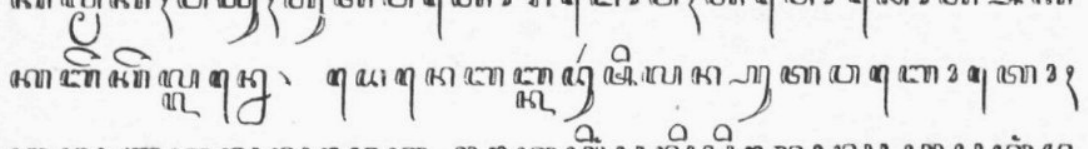

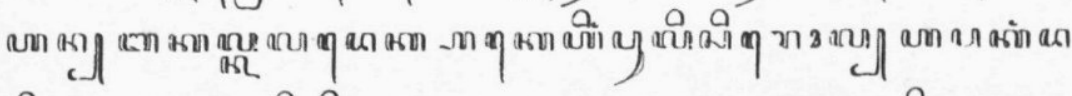

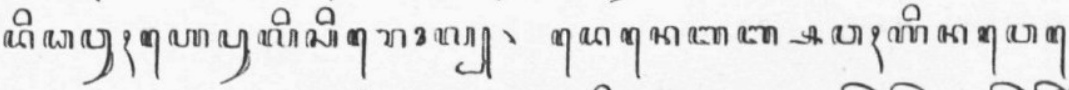

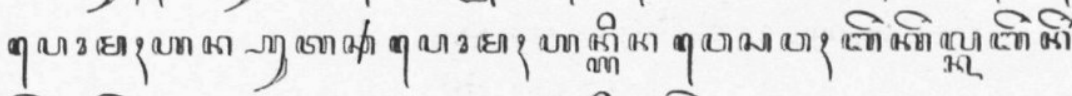

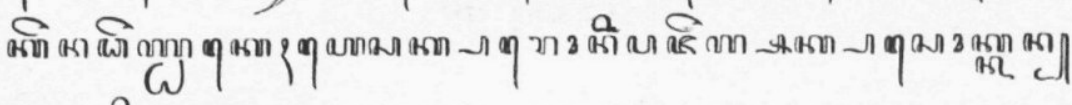

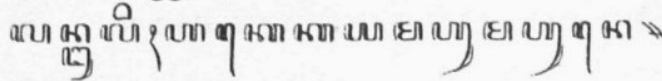

$$
\text { || } \operatorname{axn} \operatorname{axm} 11
$$

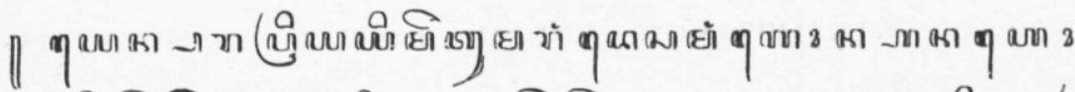

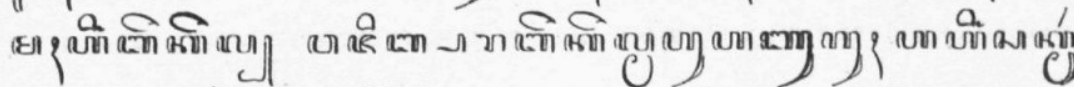

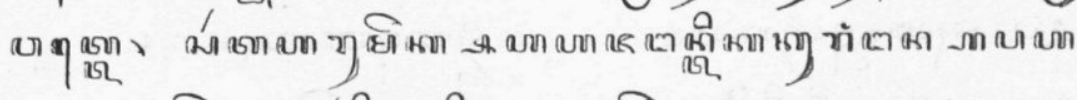

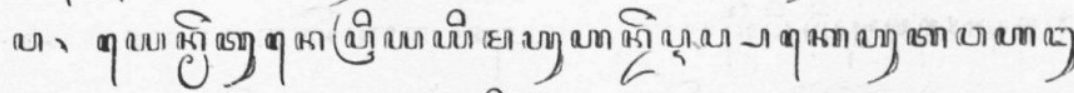

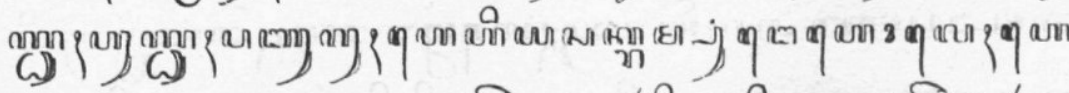

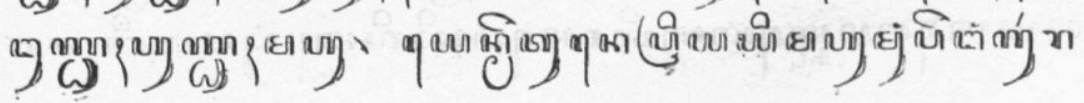


are ve go b fu Go (1) CO O O O O

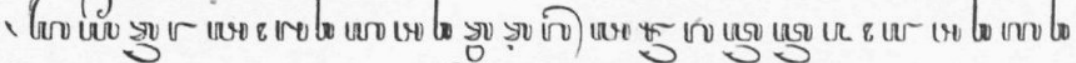
l.

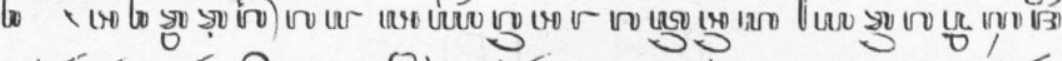

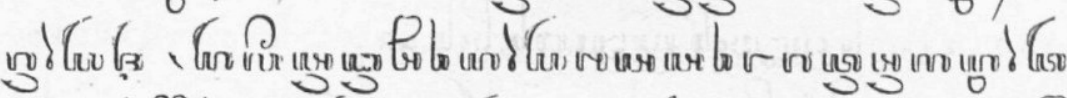

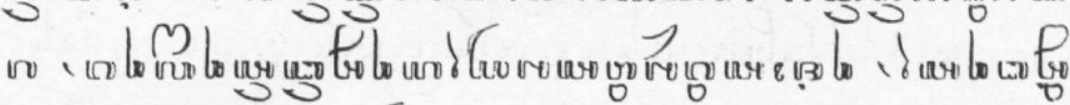
U. to

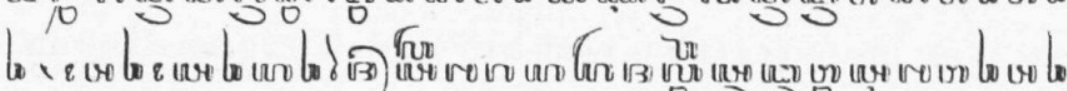

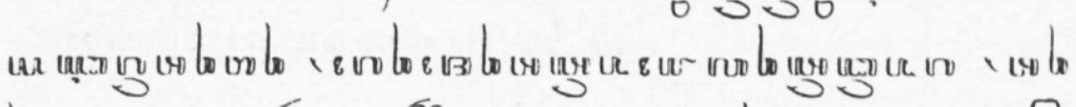

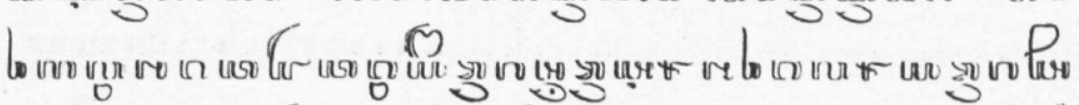

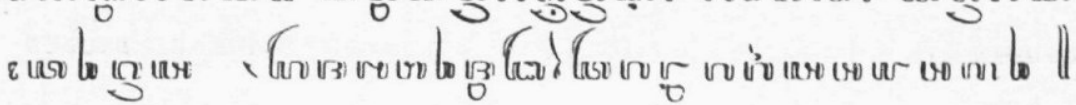
\%I

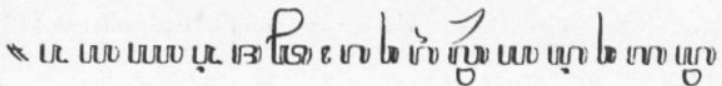

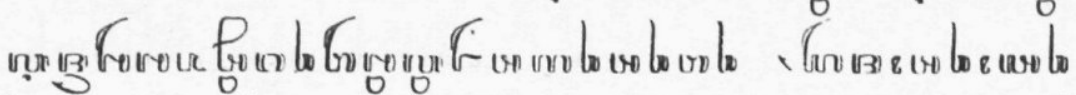

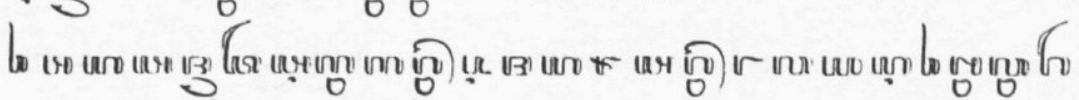

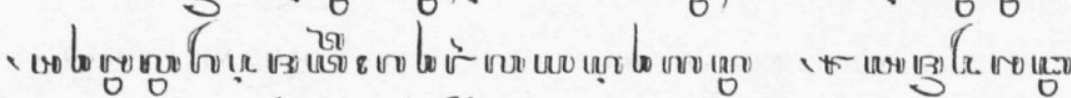

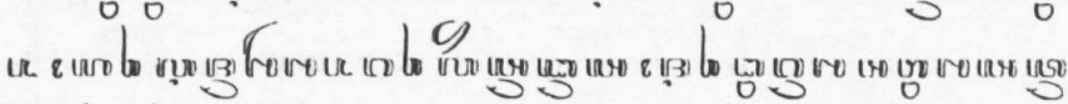

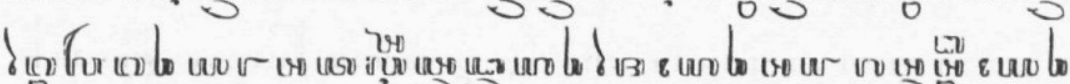

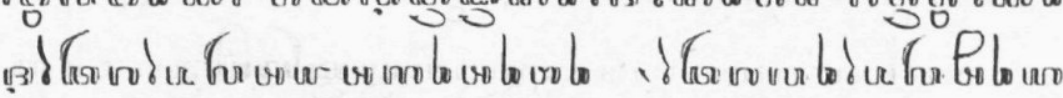

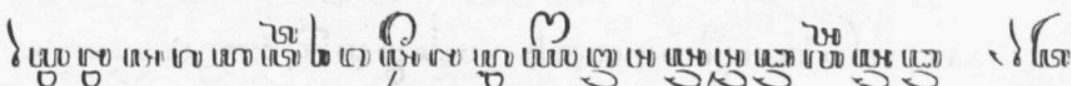

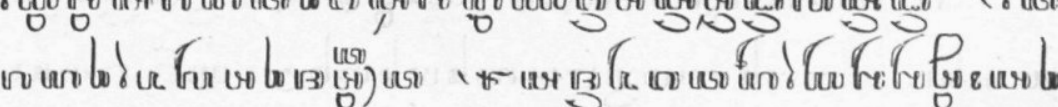

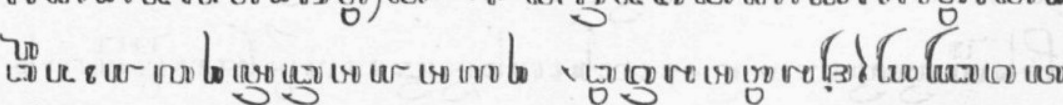

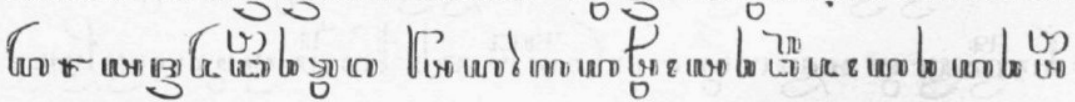




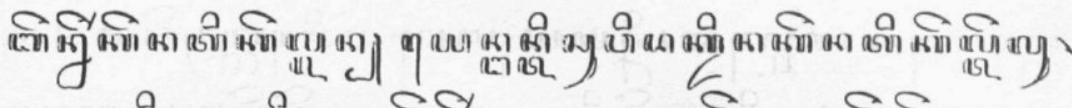

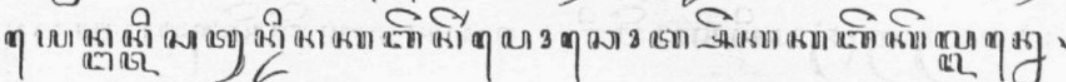

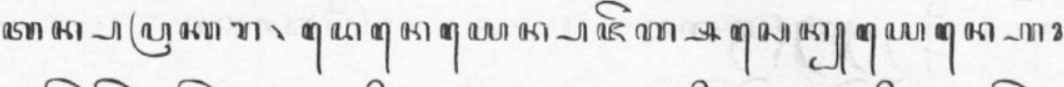

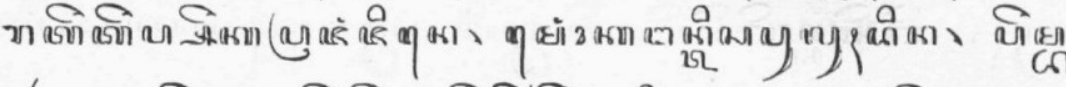

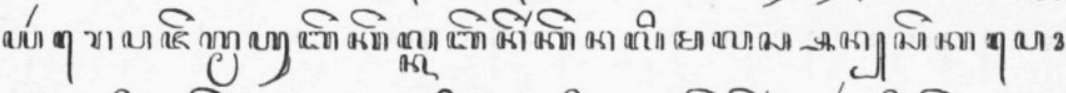

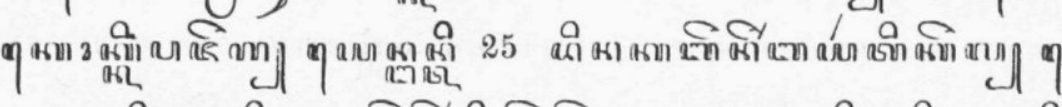

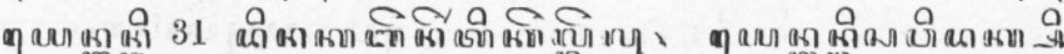
तूलद

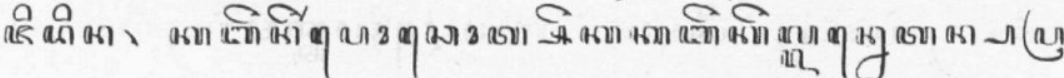

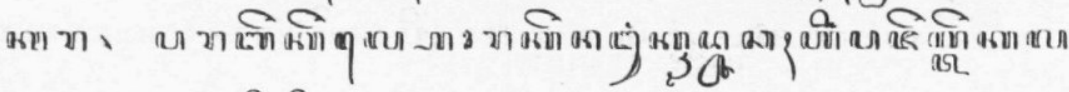

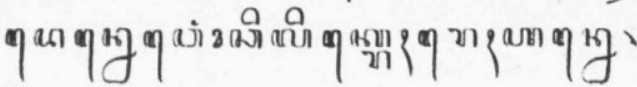

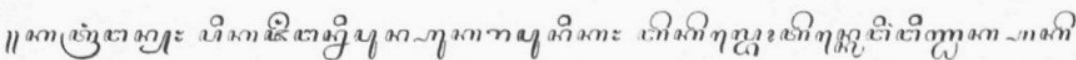

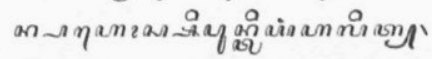

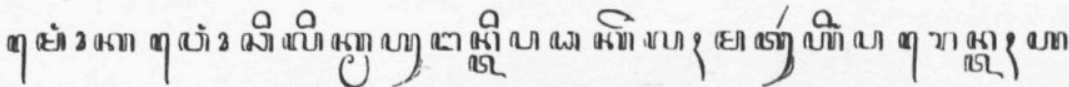

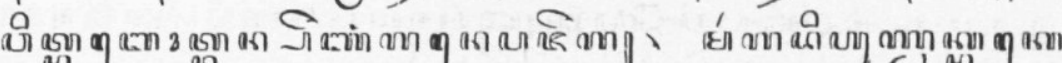

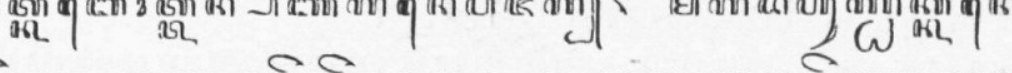

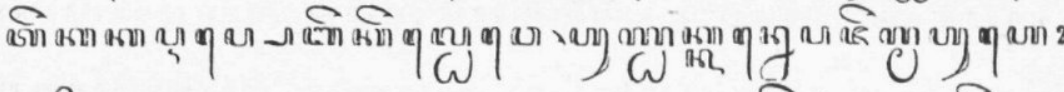
ว

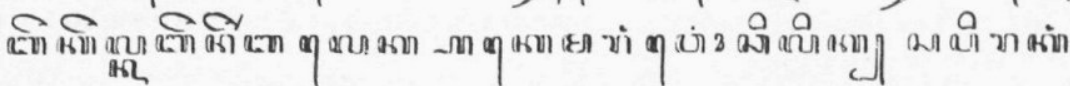

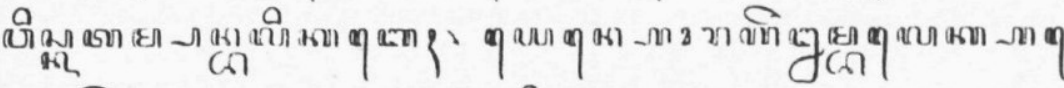

$$
\text { की }
$$

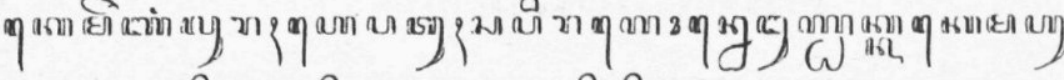

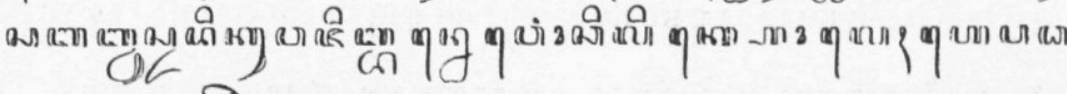

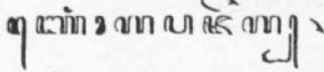

$$
\text { || } \operatorname{axn} \frac{\operatorname{con}}{4} 13
$$

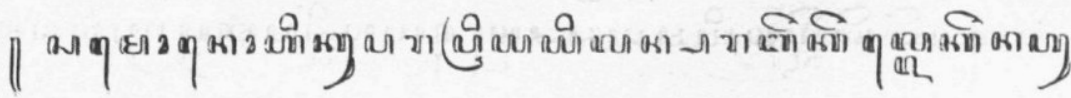




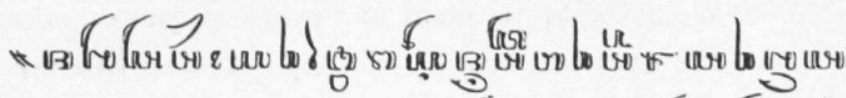

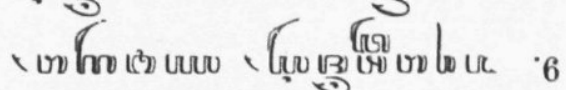

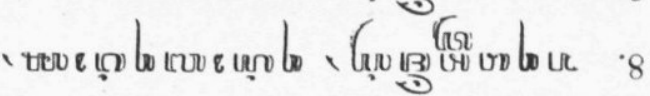

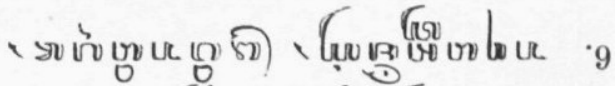

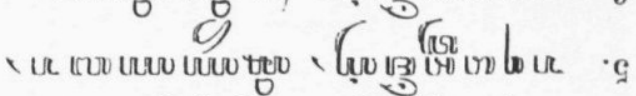

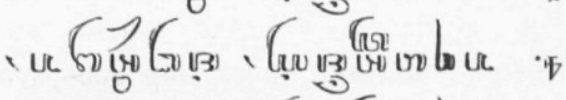

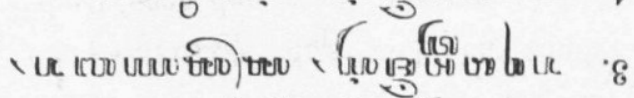

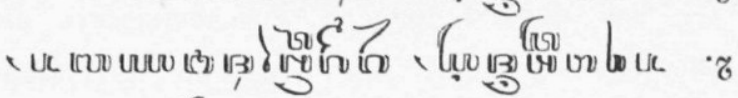

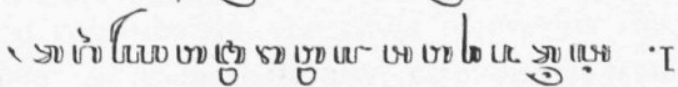

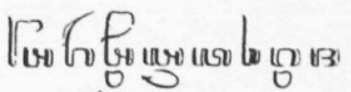

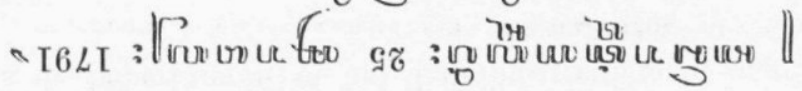

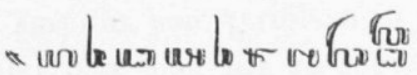
uro aro uro b

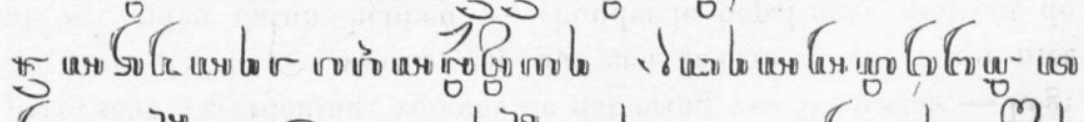

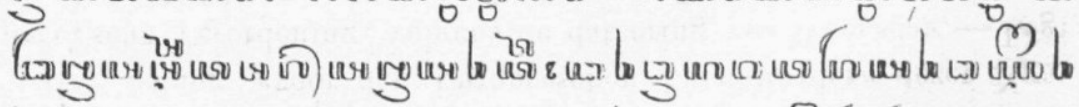

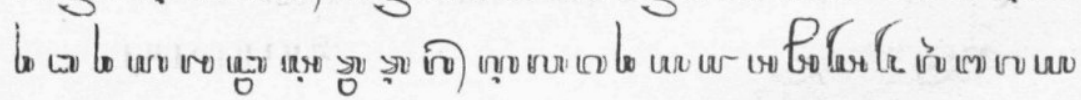




\section{Inleiding.}

Het belang "voor den Europeeschen Landhuurder" dezer Ngajogyå’sche Verordening, volgens de dateering van Woensdag - Lĕgi 23 Juli 1862, - waarin wij dus een Javaansch van zeker niet al te ouden datum hebben - "houdende bepalingen omtrent de rechten en verplichtingen der Prijaji's, die gronden in apanage hebben in het Rijk Ngajogyåkartå" blijkt o. a. ook uit de aanteekening bij beide vertalingen: "Door verhuur aan Europeanen gaan de rechten van den Prijaji op den Europ. Landhuurder over, behoudens de beperkingen in het Landhuurreglement opgenomen."

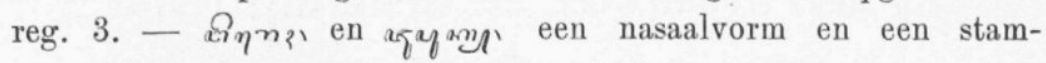
woordelijke vorm. Bij Art. 8 r. 5 wordt hierop teruggekomen.

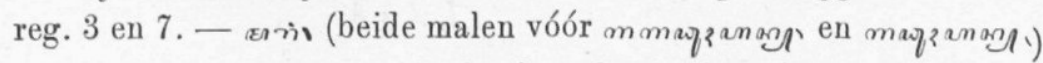
kan in zijne onbepaaldheid de beteekenis het best omschreven worden als eene betrekkings-praepositie; de eigen beteekenis van ๓т் kan geene andere zijn dan die van richting-aanwijzing. Men zie verder onze "Grammatica." § 176. p. 335 v.v. Dat wij hier mmayzonm en mayzanm dus met en zonder Reduplicatie aantreffen, is geheel naar den regel. Gramm. $§ 145$. Maar zeker is 't dat het niet altijd even gemakkelijk is , te verklaren, waarom men in een gegeven geval al of niet de Reduplicatie toepast. Ook de heer Walbeehm wijst daarop in zijn "De Woorden als zindeelen in het Javaansch", waar hij $\S 371$, p. 197 zegt van het woord cnriqum dat die vorm "moeilijk te verklaren is, te meer, wijl men in den zin van hoofilinhoul, schets

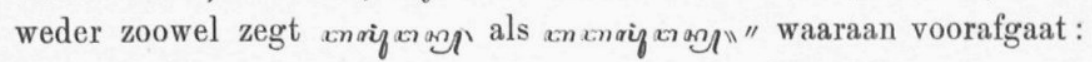
"Eigenaardig is het daarom, dat men in den letterlijken zin voor

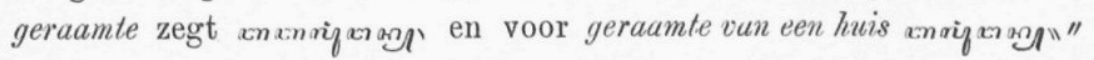
Dat er dikwijls verschil van beteekenis ontstaat als een woord al of niet geredupliceerd wordt, is maar al te waar; men denke bijv.

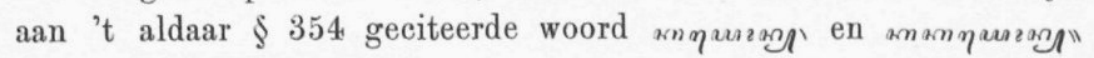
Hiermee is echter wel het feit geconstateerd, maar de waarde van den vorm nog niet aangewezen. In meer dan één geval - zooals

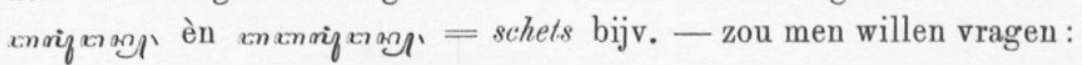
Is deze verklaring wel juist? of: Is dan het gebruiken van de Reduplicatie facultatief? - Het Woordb. i. v. anays heeft alleen den vorm: mag?anag" - Dat 't niet volkomen hetzelfde als aigm $\eta_{2}$ is, blijkt wel hier uit de constructie: manay? 
- Vergel. ook het in deze Pranatan voorkomende Nomen : ereisin

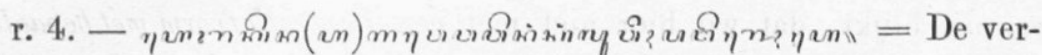
talingen hebben dezen zin vrij weergegeven. Hij kan vertaald worden: de prijaji's mogen geen gezach witoefenen (zich gezach of machtiging toekennen) hun beheer te bonen gaanile (boven hun beheer); in 't kort: meer dan linn toegestaan is. - mqun treedt als subjectswoord en als Praedicaatswoord op; in het laatste geval

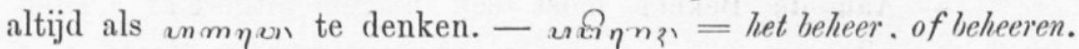
De woordvorm geeft altijd te kennen: het gesubstantiveerde, subjective, in een bepaald geval, handelen of doen van een subject als agens. Daarmee wordt de $\approx$ vorm vóór een gepraefigeerden nasaal onderscheiden van dien vóór een stamwoordelijken vorm. Zoo ook axmyang enz. Zie: Gramm. § 118, $2^{\circ}$ p. 155. - De heer Walbeehm schrijft voor dezen vorm: мақу⿰пу evenals in al der-

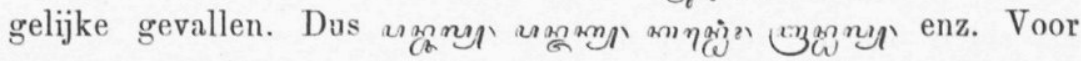
het heden is 't eene nieuwigheid, ook door enkele Javanen - naar het schijnt - gevolgd. Zou het bezwaar: inconsequentie werkelijk zooveel te beteekenen hebben, daar het schrijven van een $\mathrm{mm}$ of $\mathrm{x}$ w toch altijd alleen maar boven een overeenkomstige pasangan in hetzelfde woord mag gebruikt worden, en met deze schrijfwijze wij ons in de geheele bestaande Jav. literatuur thuis en in niet zoo kwaad gezelschap bevinden? Zoo min bij de $n$ als de $s$ kan in de bedoelde gevallen dan ook eigenlijk sprake zijn van onregelmatige spelling, daar zij blijkbaar de begeleidende klanken der pasangan's tot bazis hebben. Daar is dus geen sprake van willekeur die dergelijke onregelmatigheid zou in het leven geroepen hebben. Tegen spelwijzigingen hebben wij zooveel bezwaar niet als zij rationeel en nuttig zijn; maar dan ook alleen maar in die gevallen; en het oude, het klassieke heeft ook eenige rechten, althans het recht van meespreken.

\section{A r. 1.}

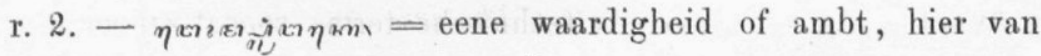

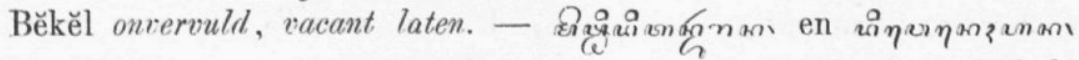
$=$ zekerlijk moet door hem aangesteld worden in die desa een Bĕkĕl; en: moet (door den prijaji) door hem aan den Bĕkĕl een piagĕm gegeven worden. Een objective voluntatiefvorm, om omtrent eenen afwezigen, een derden persoon, in een verondersteld geval iets te 
gebieden in den zin van ons: moet of zal hij dit of dat doen; waaruit blijkt, dat wij hier niet met een Imperatieficorm met bepaald object, maar met een Conjunctiefrorm hebben te doen. De cerste richt zicht onmiddelijk tot een tweeden persoon; de tweede beveelt, gebiedt, schrijft iets voor of verordent ten opzichte van een derden persoon. De Imperatief met bepald object in den di-passiefv $0 \mathbf{r m}$ is onbestaanbaar.

r. 4. - Aan de Běkěl's moet een piagĕm uitgereikt worden

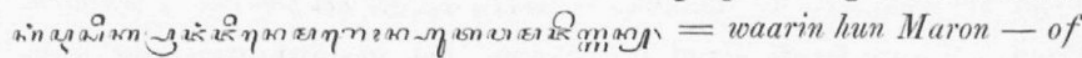
Madjĕggan - overeenkomst iluidleligk zij omschreven. De heer O. vertaalt hier Maro-stelsel (d. w. z. in natura), doch in het "Eindresumé" vindt men p. 83: Mémaro-stelsel; en wordt Madjëggan door beiden omschreven met: in geld of andere voorthrengselen. Het Lexicon

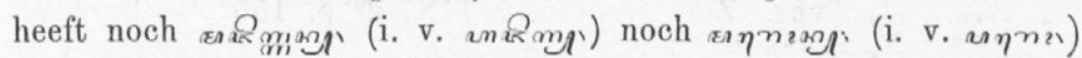
In de Woordenlijst van de Nooy vindt men een ander (overigens

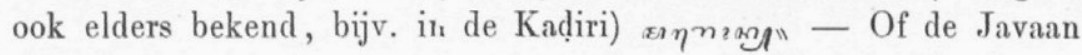

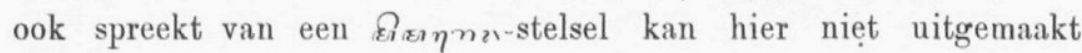
worden; doch blijft de vraag over aangaande de beteekenis van

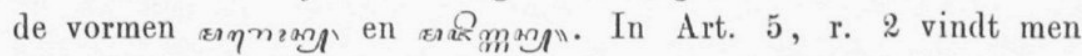

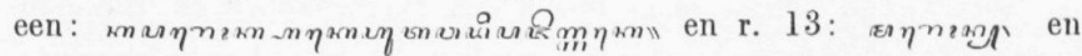

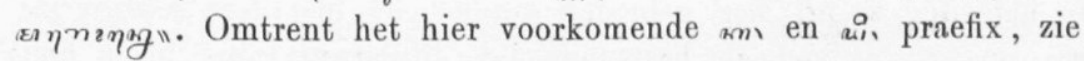
men Art. 5, r. 29 de Aanteekening.

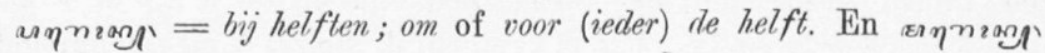
$=$ bij helften, voor of om (ieder) de helft iets doen; in casu: een overeenkomst sluiten, dat Běkĕl en Lurah Patuh ieder de helft van de opbrengst (voortbrengselen) van de apanage zullen hebben.

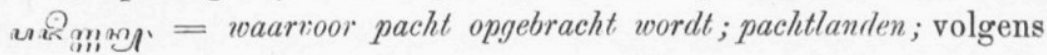

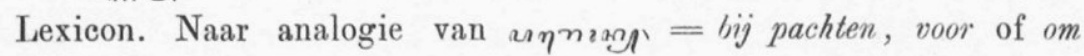
een met, elkaar overeengekomen pacht. вภ man $=$ bij pachten, voor een met elkaar overeengekomen pacht iets doen, namel. een pacht in geld of andere voortbrengselen aan den apanagehouder opbrengen.

Werd вүпгмл alzoo een technische term, zoodat wij ook Art. 3

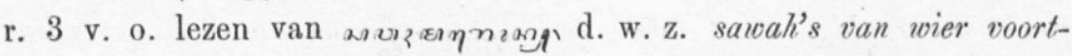
brengselen Běkěl en Lurah Patuh ieder de helft krïgen; zoo vindt men

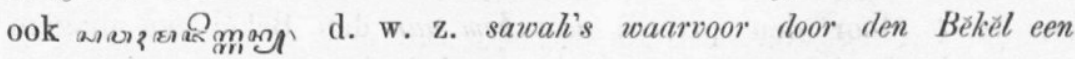
padjëg in geld of wat anders aan den Apanagehouder worilt opgebracht. 


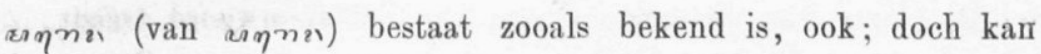
alleen beteekenen: iets halveeren, in tweeën deelen; en dan verder als technische term: voor de helft ran de oplrengst eene apanage belueeren door den Bĕkěl.

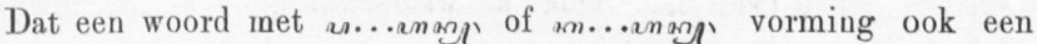

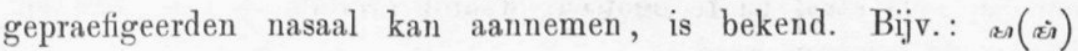

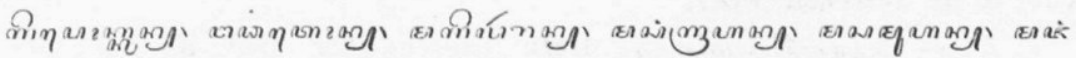

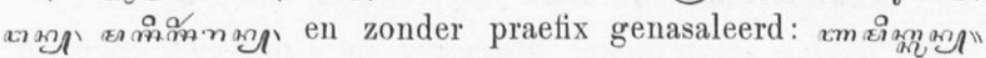

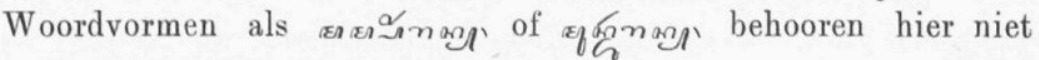

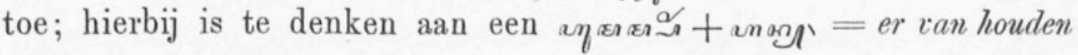

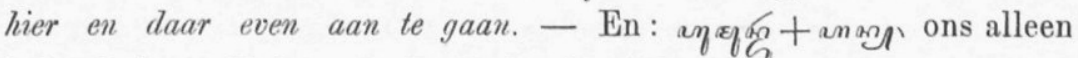

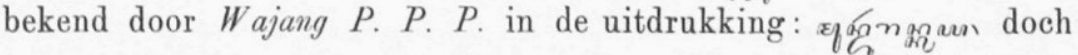

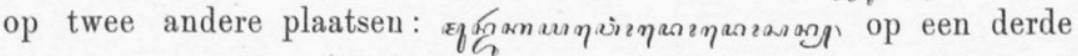

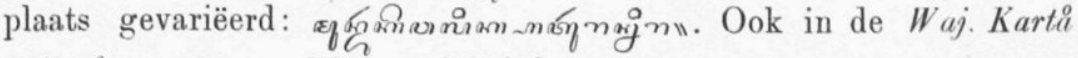
Wijogå p. 56, en Waj. Djülädàrà Rabi p. 140 en 316 vindt men

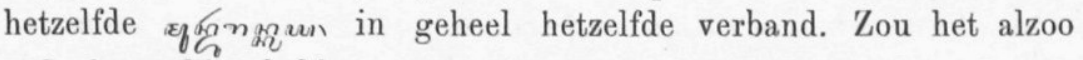
wel den schijn hebben een wajang-term te zijn geworden, dan is 't toch niet te vergeten, dat de term ook wel in 't dagelijksch leven voorkomt. Althans T. Roorda teekende p. 387 aan, dat: "volgens

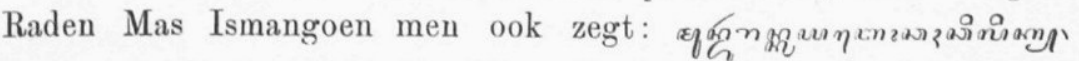
= evenals kinderen, kinderachtig." Doch च的m - in analogie met вл⿻上丨ма - kan in reëelen zin bezwaarlijk iets anders beteekenen dan: geneigd zijn tot zich altijd maar achterwaarts te bewegen; dus fig. z. v. a.: zich terug trekken, in den zin van: zich, uit bescheidenheid of verlegenheid op den achtergrond plaatsen.

r. 6. - asaquกิเsaq - als er onderling geschil bestaat tusschen Bĕkĕl en Prijaji. Zie Wdb. i. v. anaq". In deze term ligt eene reciproque beteekenis. Zie onze Aanteekening in de "Corrigenda" der Grammatica, behoorende bij p. 293 r. 17.

r. 6. - ถูก์ voor anยูกทํ. - Zoo ook aan het slot van

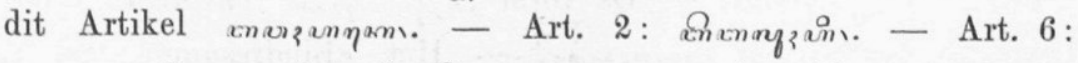

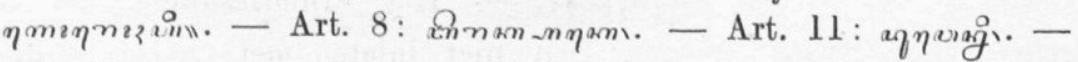

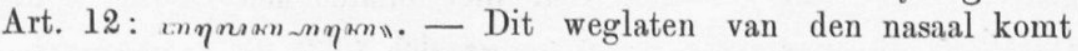
wel meer voor; doch daar het N. Jav. nu eenmaal bij de verlengde vormen van een praedicaatswoord een nasaal verlangt, is dit weglaten als eene slordigheid te beschouwen. Waar de nasaal 
in de plaats van de eerste aksårå van het stamwoord treedt, zal men deze schrijfwijze dan ook wel niet aantreffen. Zie verder beneden Art. 8 r. 5 .

Van denzelfden aard is ook het hier gedurig voorkomende sм⿻я in plaats van ası. Ook a] waarschijnlijk eene schrijfwijze om de spreektaal na te bootsen; waarop Gramm. $\$ 176,126$ en 128 reeds gewezen werd.

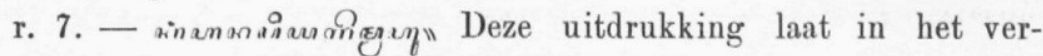
band geeu twijfel omtrent de bedoeling toe; zij komt ongeveer zoo meer voor. anm krijgt hier de beteekenis van: vervat is in. Doch ò eene andere woordkeus of het plaatsen van een praepositie na enas, zou alle bezwaar opheffen. - Het "Eindresumé" laat de

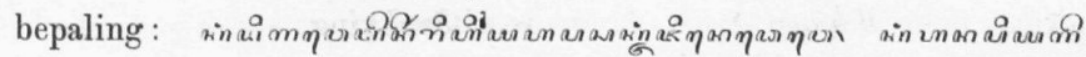
छ̋ politiehoofd worden gebracht," dat bij O. zóó niet voorkomt, maar de tekst meer op den voet gevolgd wordt. - En de vol-

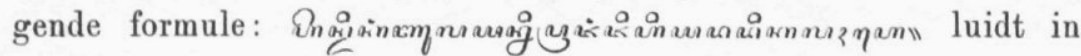
het "Eindresumé": degene, die zich niet aan de bepalingen omtrent (?) de piagĕm heeft gehouden, zal in het ongelijk worden gesteld." - amnsangig = zich ergens niet aan houden.

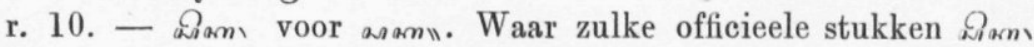
hebben, houdt 't bijna op spreektaal te zijn. - Het slot van het Artikel heeft woordelijk het volgende: "Als er een prijaji in geschil is met zijn Bĕkĕl, en er bestaat nog geen piagĕm, zal het rechtsgeding niet in behandeling komen (geen voortgang hebben), wegens hun beider eigen nalatigheid (verzuim). De prijaji's en hun Běkěl's, als zij eene rechtzaak hebben, hebben zich te wenden tot het politiehoofd, tot wiens ressort de zaak behoort." anmms ontbreekt in het Lexicon; het heeft wel anannagin".

A. r. 2 .

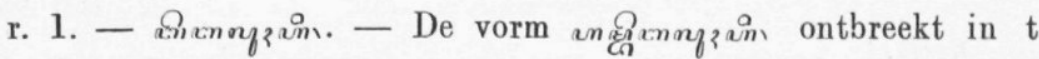

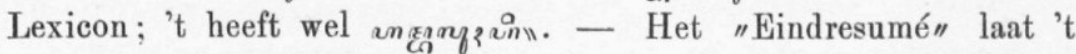
geheel weg. Want "mogen zich niet inlaten met" aldaar is de

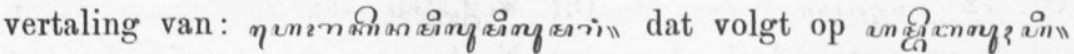
Is O.'s vertaling van dit woord de juiste, dan is 't: het iemand op eenigerlei wijze moeilijk maken, i. c. den Bĕkĕl ten opzichte van zijne verplichtingen en diensten. Maar 't woord kan ook betee6e Volgr. V. 
kenen: iemand op eenigerlei wijze helpen, bijstaan, zijn partij kiezen in een twist of verschil.

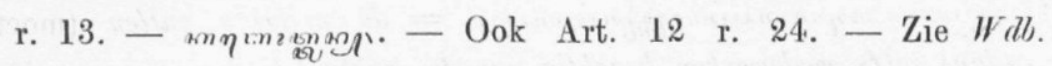

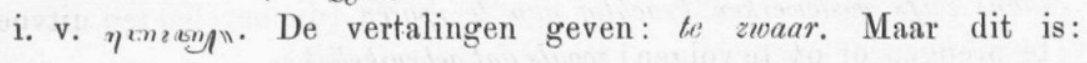
mกๆ

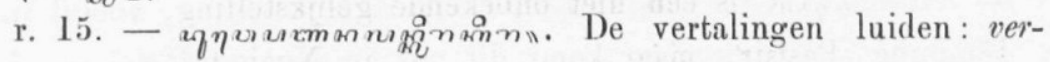
meenen of vermoeden. Eig. : het vermoerlen hebljen en vermeenen.

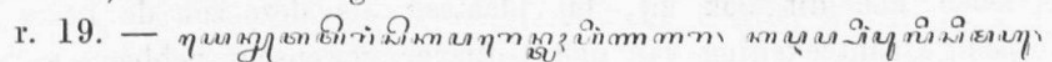

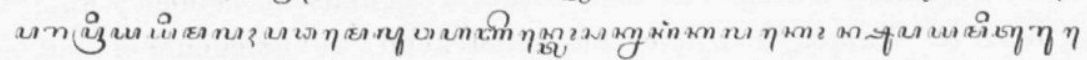

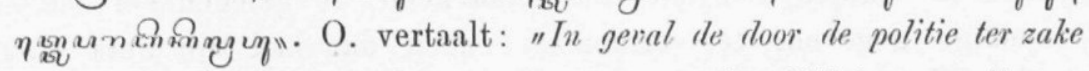
gegeven bevelen inderdaad met medeweten van het Rijksbestuw zijn gegeven, moeten de ambtenaren zelfs kracitig medewerken tot de nakoming daarnan door de Bæ̌ǩr's." - Het "Eindresumé" heeft: "Ingeval de ter zake gegeven bevelen door het politiehoofil met merleneten van het Rijksleshun zijn gegeven, zal hij (de Apanagehouder) moeten medewerken. tot de stipte naleving der gegeven bevelen." - De aandacht zij hier allereerst gevestigd op de beide conjunctiefvormen

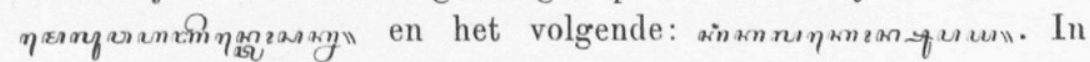
de vertaling: zelfs krachtig medewerken zou krachtig eene bepaling

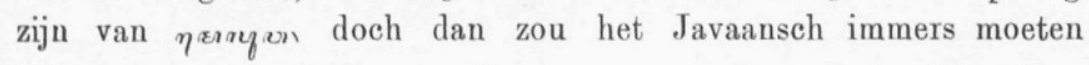

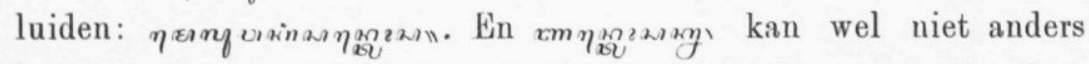
beteekenen dan: dat zij (de prijaji's) stevig, hecht, standvastig maken, sterken; tot standvastigheid en volharding aanmoedligen; tot nolharding aansporen; er kracht aan bijzetten. Maar dan volgt de vraag: wat

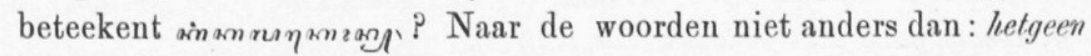

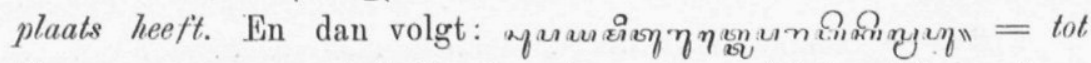
(d. w. z.: tot oogmerk hebbende, strevende naar) het gewillig opvolgen, naleven of nakomen der Běkěl's namel. van de hun gegeven bevelen. Een gelijke constructie vindt men bijv. in "Roorda's Pandji-verhalen in het Javaansch", door dr. J. G. H. Gunning, p. 5, r. 18.

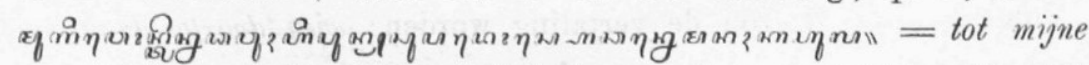
geruststelling; d. i.: tot oogmerk hebbende mijne geruststelling. En ald.

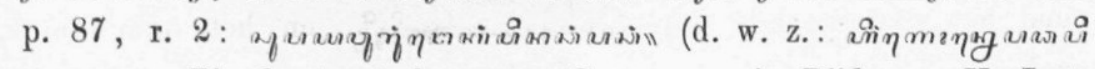
masianis.. Zie de Aanteeken. van G. op sim in Bijdragen K. Inst. v. d. T. L. V. kunde $6^{\circ}$, I, p. $2-3$ v. d. Overdruk) $=$ tot oogmerk hebbende, strevende naar het niet doorgaan van haar verloofd worden. 


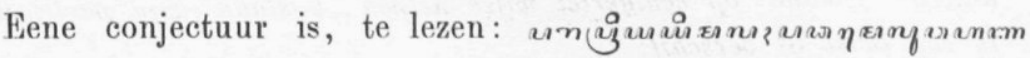

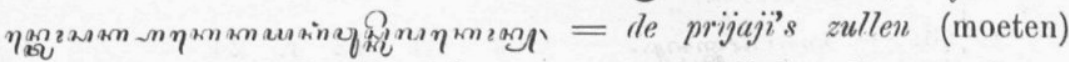
(dan) zelfs mellewerken krachtig aan te sporen [die bevelen ten uitvoer

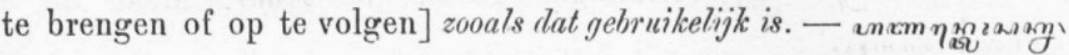

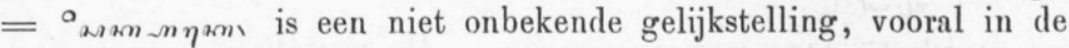
Tĕmbung Pasisir; maar komt dit ook in Ngajogyå wel voor? Doch hoe dit ook zij, bij platsen als deze zou de Lezer wel eenige aanteekening van den Uitgever geweuscht hebben, waartoe deze te Ngajogyå zijnde zoo uitstekend de gelegenheid had de noodige gegevens te verzamelen, doch dan had zijn werk waarschijnlijk een ander karakter gekregen dan met zijn plan overeenkwam.

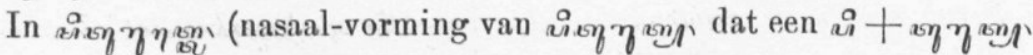
voorstelt. Gramm. $§ 123)=$ het gevillig opvolgen, naleven of nakomen (der bevelen door de Běkěl's) hebben wij een nasaalvorm als subjectswoord. Gramm. $\S 86$, p. 79.

r. 21-25. -- In deze regels staat geen enkele Pådå-lingsi̊, die er voor de duidelijkheid wel in gewenseht zou zijn. 't Is trouwens niet de eenige plaats!

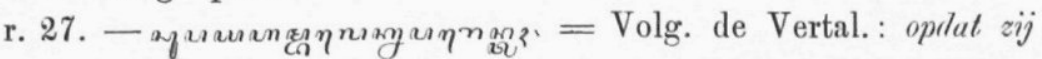

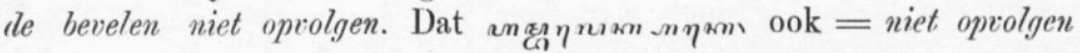
v. bevelen kan beteekenen ontbreekt in het Lexicon. Vergel. ook

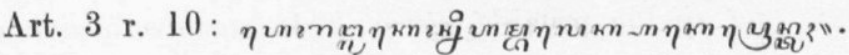

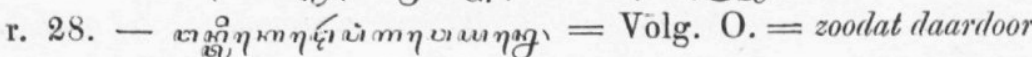
achterstand in het werk ontstaat. In "Eindresumé": en llaarloor de geregelde gang van zaken worlt gestoord. Zie Woord.b. i. v. $\eta$ жn $\eta$ द्वा॥

r. 29. - छт

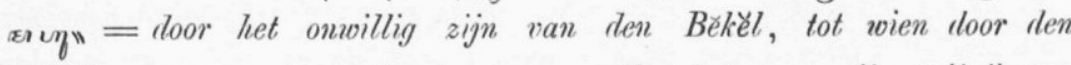
prijaji an «s gezegd werd, d. w. z.: welke het door zijn prijäi ver-

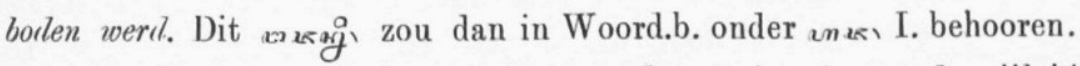
Volgens enas II. zou de vertaling worden: wien daartoe de vrijheirl gelaten was, het toegelaten was ,loor den prijaji. Maar dit rijmt niet

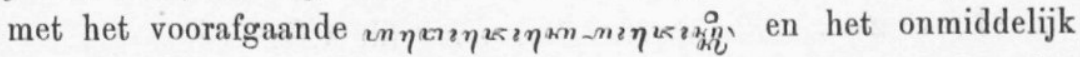

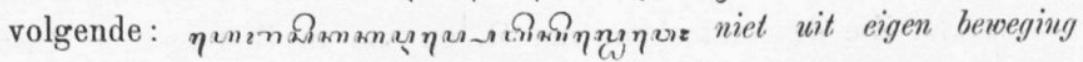
van den Běkěl

A r t. 3.

r. 1. op te nemen. 


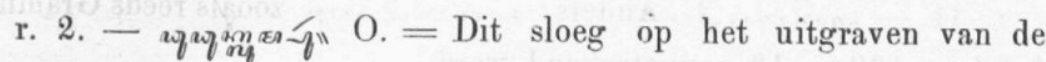
gracht om de bèntèng (de kraton), het graven van leidingen in de stad, enz.

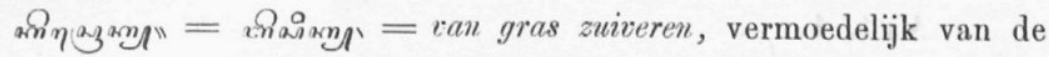
Alun-alun.

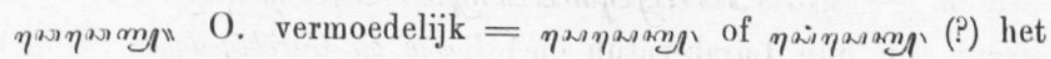
vernieuwen of repareeren van de asquи (Ananmg

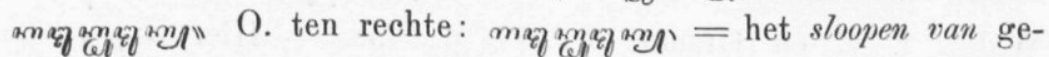
bouwen, die niet meer gebruikt of veranderd moeten worden.

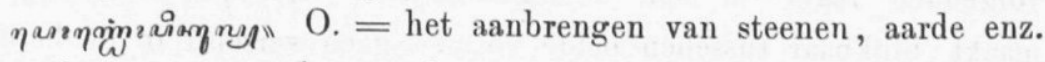
voor bruggen en andere werken. - qasenginn (het voor zich uit-

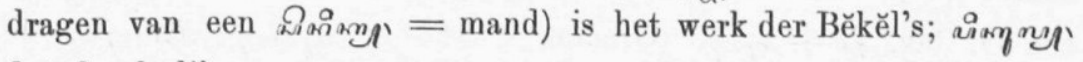
dat der kuli's.

Bovengenoemde werkzaamheden worden, behalve een enkele maal

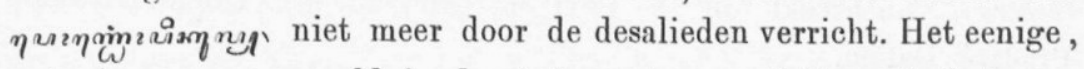
wat deze nog geregeld in de stad moeten verrichten, is het aanwitten van de muren der Noordelijke en Zuidelijke alun-alun's, der masdjid-poort, van de Sitinggil, en van de muurtjes in den Chineeschen kamp.

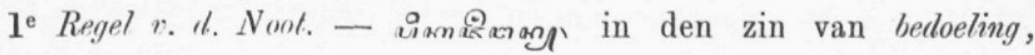
beteekenis, komt in het W.d.b. niet voor.

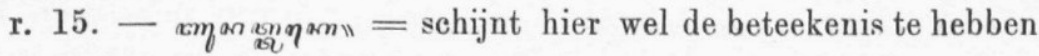
van besnijden in het algemeen. - In De Taalsoorten in het Javaansch, door "A. H. J. G. Walbeehm" komt 't p. 259 als K. I. van

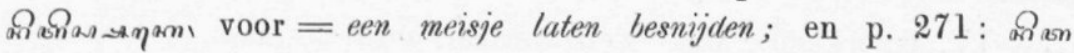
añ $\eta_{\text {an }}$ iemand laten besnijden. In de Javaansche Woordenlijst van

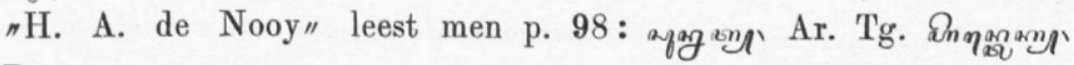

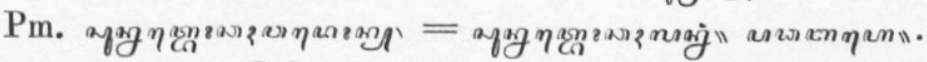

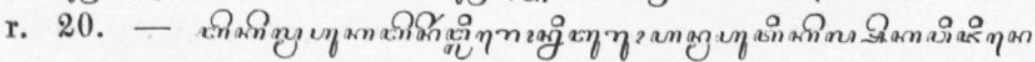

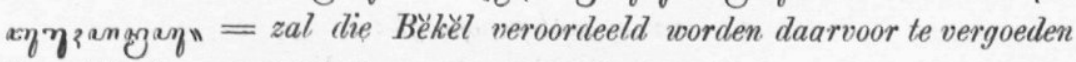
het dubbele van het bedrag der (aan die huurlingen) betaalde loonen.

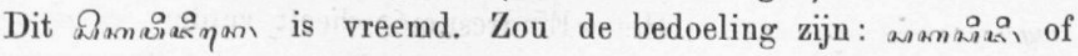

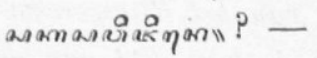

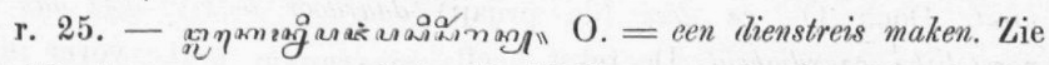
W.d.b. i. v. макі en asaias. En Walbeehm, De Woorden als Zindeelen, § 353 , p. 185. 


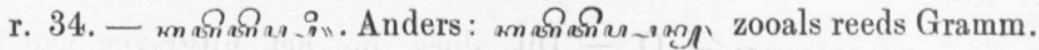
$\S 97$ p. 109 r. 13 aangeteekend werd.

\section{A r. 4.}

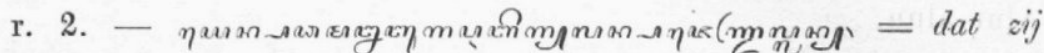
öinnen (bij hun Lurah-patuh op-) komen op Garěbĕg-dagen en bij de komst van den Gouverneur-Generaal. - quan als Voegwoord zie

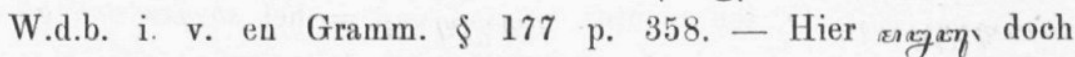

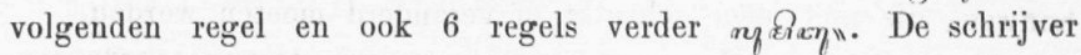
makt blijkbaar tusschen beide vormen geen verschil in de beteekenis, gelijk ook elders en zeer dikwijls voorkomt. Toch is encycq,

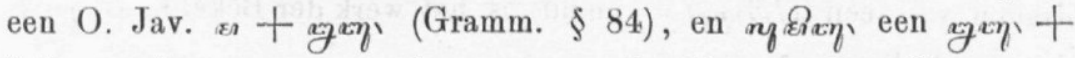
infix $\mathrm{u}+\mathrm{m}$. - мүак(mmiag = komst van den GouverneurGeneraal ontbreekt in 't Lexicon. Zie boven: Inleid. Nawålå Pradåtå Dalěm.

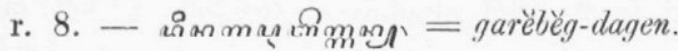

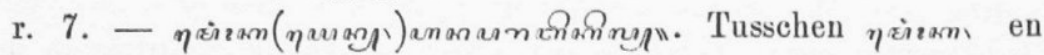
anas moet men een quås denken. - un schijnt hier vóór ํㅐำ in het Enkelvoud op te treden; zooals 't ook elders voorkomt. Ook bijv. in Waj. Pålåsårå bij unкmå̊冈 W.d.b. i. v. asn II.

r. 9. - masnхтоп. Bij herhaling komt deze term voor. De

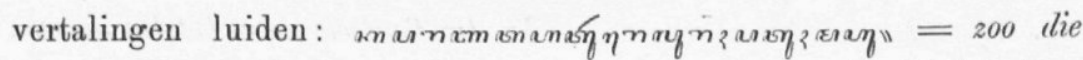
klacht vau den L. P. gegrond wordt bevonden. snasn in W.d.b. i. v. an IV. is bekend. Maar welk vertaalwoord zal men er hier voor geven?

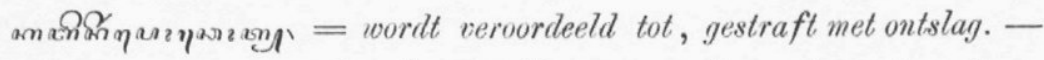

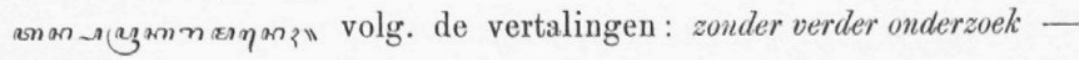
of: zonder dat er verder wat aun te doen is, de zaak nog nader in behandeling kan komen; z. v.a. onherroepelijk?

r. 12. - anmiarminang volg. de vertalingen:= iemand in ongelegenheid brengen. - Het "Eindresumé" lieeft verder: en daardoor verwarring wordt veroorzaakt in het opvolgen nan het Rijksceremonieel. Doch O: en deze (de prijaji) daardoor te kort doet aan de

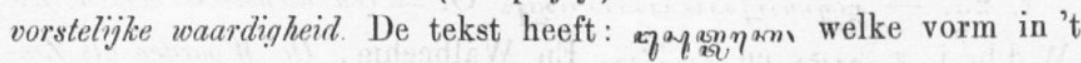
W.d.b. ontbreekt. 


\section{A r t. 5.}

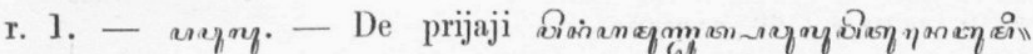
Volg. O.: zign bevoegd om naar believen de opbrengst nan hnnиe apanagegronden te trekken. Het "Eindresumé: zijn benoegd om de pacht van hunne apanagegronden... te heffen. Het W.d.b. heeft asagay niet.

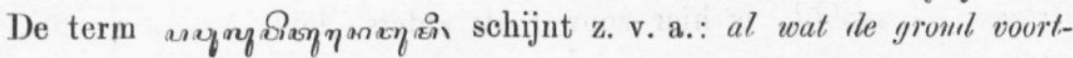
brengt te beteekenen. Vergel. W.d.b. i. v. eqnegn.

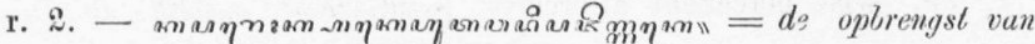
de apanage volgens het maro-slelsel in natura of in geld en andere voortlsrengselen trekken (heffen). Vergel. W.d.b. i. v.: in

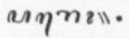

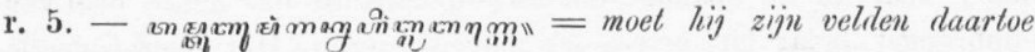
beschikbaar slellen. - $\underset{n}{\operatorname{man} \eta m}=z i j n$ velden. In deze Wetten II

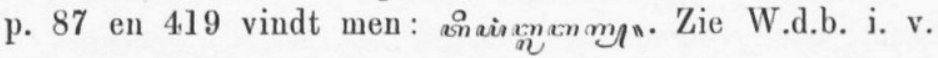

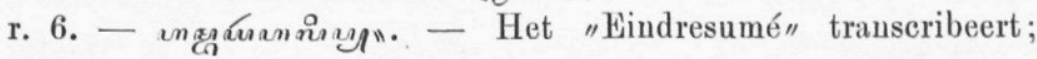
Alib. - Volg. O. = vooruitbetaalde pacht. - Ontbreekt in het Lexicon. - Eene nadere omschrijving van de Alip vindt men in de "Regeling houdende voorschriften omtrent vaste Bĕkĕl's erven." (I. p. 219 v.v., III. p. 55 v.v.). In Art. 4 wordt gezegd omtrent hetgeen waarop een ontslagen Běkĕl recht heeft, en bekend is onder den naam Alip, bestaat uit "de volwassen bambu's en kokosnoten, en alle andere vruchten of gewassen, op zijn eigen, het vaste Běkĕl's erf, die rijp zijn om geoogst te worden. Het overige moet gelaten worden zooals het is, en door den nieuwaangestelden Bĕkěl gekocht worden. Het tot zich nemen van de Alip door den ontslagen Bĕkĕl moet geschieden in tegenwoordigheid van de Bĕkĕl's der 4 naburige desa's als getuigen." De vertaling: vooruitbetaalue pacht schijnt dus in zooverre minder juist,

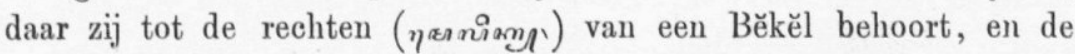
zaak geheel tusschen een ontslagen Bĕkĕl en zijnen opvolger afgehandeld wordt. Waar nu in het Artikel dat wij bespreken, sprake is van eenen Lurah-Patuh, die de pacht van zijn apanage volgens het Madjĕggan-stelsel wenscht te veranderen in die volgens het Maro-stelsel, moet liij natuurlijk de Alip als aanwezigen Bĕkĕl vergoeden, daar die anders voor dien Bĕkĕl verloren zou gaan.

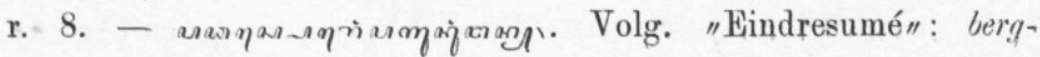


gronden; doch O. = berggronden en dergelijke. Zie W.d.b. i. v.

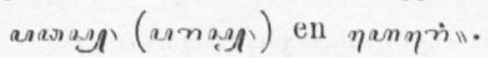

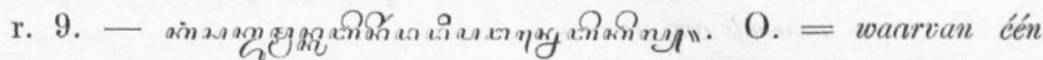
deel aan den Běkèl tot zijn onderhoud (als lungguh. Volg. Winter: patuh)" toekoml. In "Eindresumé":.... Běkēl als lungguh wordt. afgeslaan. - an 응 is hier zoowel als elders, bijv. Art. 3 r. 20 en Art. 4 r. 9, hoofdwoord v. h. praedicaat. Zie beneden Aanteek.

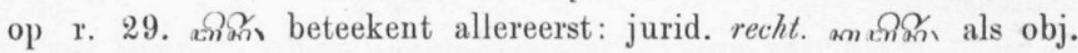
vorm: jurid. als reclit vastgesteld worden. En van daar verder in vertaling ook: veroordeeld tot, gevonnisd worden.

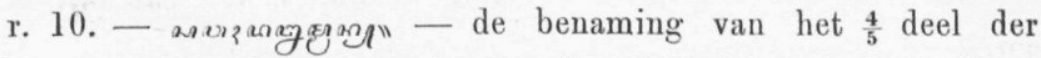
velden, waarvan de apanage-houder de helft of het derde deel van de opbrengst, naar het gewas is, mag vorderen. Het overblijvende

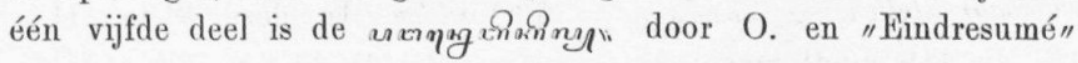

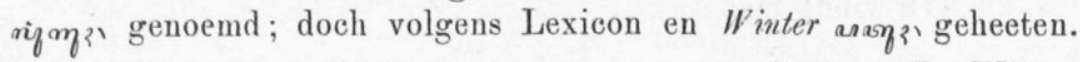
Een rigm? heet dan: de apanage van een prijaji. - In Wiuter Zam. I. No 1 leest men van een ġm $^{2}=$ apanage van drie djung's (= 12 karjå, z. v. a. bau) waarvan de Bĕkĕl als мләэ één kikil (= $\frac{1}{2}$ djung) $\mathrm{kreeg}$; in dit geval dus één zestle deel van de apanage; en bracht deze Bĕkĕl als padjĕg 4 reälen van 26 wang gemiddeld per djung op. Dit gold Suråkartå. - In ons Artikel lezen wij 5

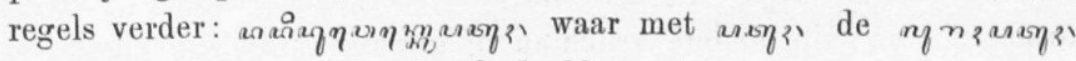
of prijaji, de apanagehouder bedoeld wordt.

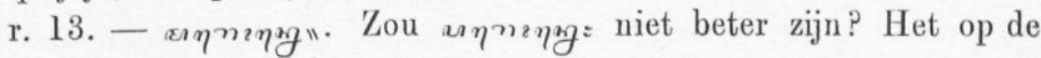

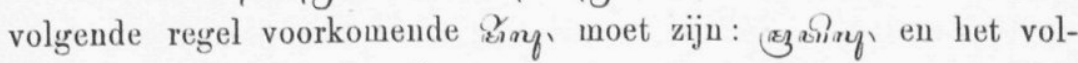

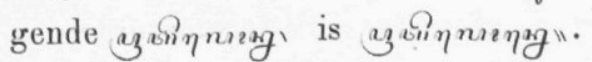

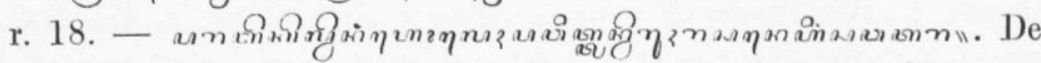
vertalingen geven hiervoor alleen maar: tegen genot van een klein deel der opbrengst. - Onder anviman zal wel te verstaan zijn: de eerstelingen of zoo iets.

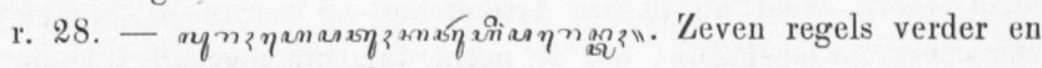

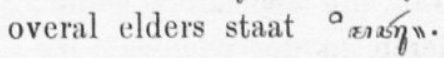

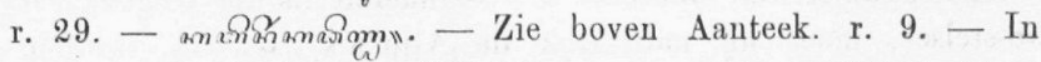
Art. 3 r. 27 is het: an

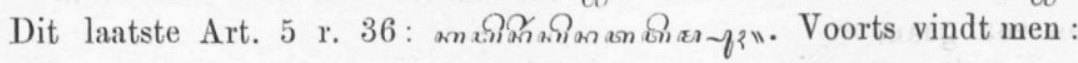

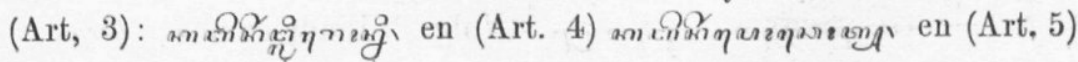




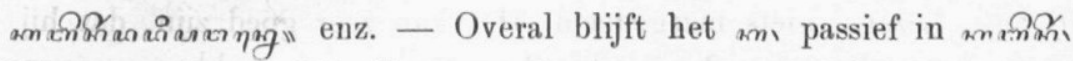
behouden; maar bij भrom wordt èn $\mathrm{mm}$ passief èn aล passief gebruikt, zonder dat men daarvoor eenige dwingende reden kan

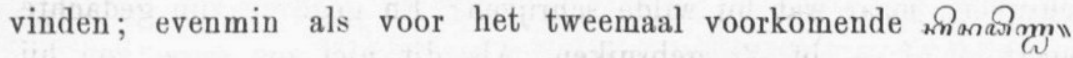
in Art. 3. Dat overigens $\mathrm{m}$ en 오 wel meer zoo afwisselend voorkomen is bekend. In Art. 9 komt, in geheel denzelfden gedachtengang r. 13 гіяgв kan daarom niet gezegd worden dat $\mathrm{mm}$ en 으 in deze zinnen dezelfde grammatische waarde hebben en ook niet dat 't voor den schrijver onverschillig was. Wij weten eenvoudig niet, wat de schrijver bij die vormen heeft gedacht, wij nemen alleen aan, dat hij precies schreef wat hij dacht. 't Eerste is: loor hem verduisterd. werd; en het tweede: achtergehouden werd. Zie de Aanteek. daar. En zoo kan het zijn, dat de schrijver bij het een aan eenen agens

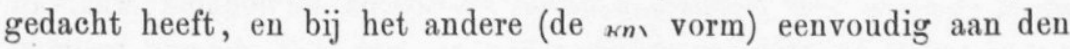
objectiven staat of toestand van het Gramm. subject (logisch object). Maar juist dit, of ieder schrijver daar wel aan denkt, is de vraag, en veelal moeilijk uit te maken. Overigens zie men Grammatica $\$ 102$ p. 127. De heer Walbeehm zegt zelfs in zijn: De Woorden als Zimuleelen in het Javaansch p. 63 \& 124: "Toch zou men zich vergissen, wanneer men meende, dat de gevallen, waarin men den eenen of den anderen vorm (namel. am of ån) moet gebruiken, scherp afgebakend of bepaald zijn. In de meeste gevallen toch kan men beide gebruiken, en dan doet zelfs veelal het meer deftige passief met am dienst als Kråmå voor dat met 오." Op dit "meer deftige passief met an " leggen wij even den vinger, in verband met hetgeen wij schreven Grammatica $\S 98$ p. 109: "men schijnt dit am dan als meer bevredigend voor het gehoor, wat deftiger, meer gedistingueerd te beschouwen," en hetgeen men vindt in "Tijdschr. v. h. B. B. 1898 p. 254. Desniettegenstaande blijft het verschil van beteekenis bestaan, en is het beslist niet waar, dat "men in de meeste gevallen beiden kan gebruiken." Als de schrijver de boven aangehaalde woorden

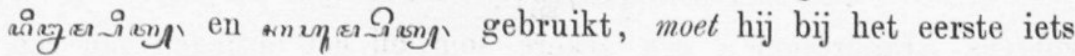
anders gevoeld en zich voorgesteld of gedacht hebben dan bij het tweede; het doet er weinig aan toe of af, of wij al dan niet een reden kunnen aangeven, waarom hij zóó en niet anders schreef; de zaak is maar of hij schreef wat hij dacht, doch daarvan heeft 
hij ons, Lezers, niets meegedeeld. Het kan zeer goed zijn, dat hij

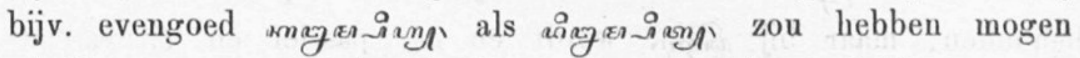
schrijven; maar het is niet de vraag, wat hij zou hebben mogen schrijven, maar wat hij wilde schrijven? En gegeven zijn gedachte moest hij òf $x$, ò å gebruiken. Als dit niet zoo ware, zou hij òf gedachtenloos geschreven hebben, ò zijne eigen taal niet hebben verstaan. Dat dit het geval zou zijn met den Schrijver van deze Wet zal men van ons niet hooren; dat het met anderen wel het geval kan zijn zullen wij niet tegenspreken. Alleen zeker is, dat het Javaansch nog niet zulk een "versleten" taal is, dat men twee zulke belangrijke vormen met elkaar zou verwarren en als volkomen gelijkwaardig beschouwen.

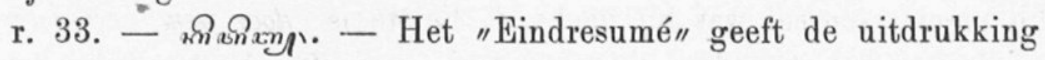

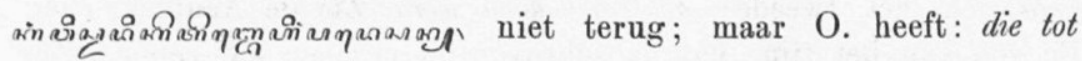
grensteekens in lun Běkělschap dienen. Namelijk de boomen, waarvan hier sprake is. Hebben wij hier aan op zich zelf staande boomen te denken, of het geboomte dat gewoonlijk eene desa geheel om-

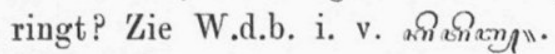

\section{A. t. 6 .}

r. 1. - irizmz» waarvoor in 't Lexicon esrigm $\eta_{3}$ gewoonlijk

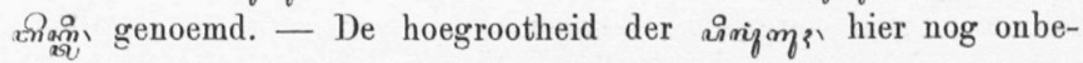

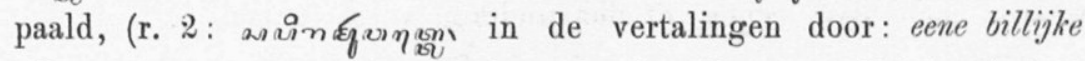
pilungguh weergegeven) werd later in de "Pranatan Bĕkĕı" Art. 5 nader geregeld, en het bedrag der pachtschat tot grondslag genomen. Zie boven Aanteek. op Art. 5 r. 10.

r. 6. - airizmร死m = het bedrag, dat bij zijne aanstelling, door eenen Bĕkĕl aan zijnen Lurah Patuh wordt afgedragen. Zie

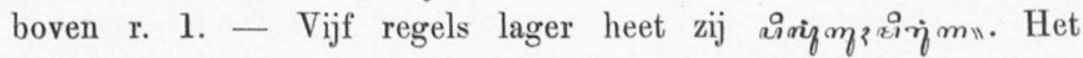
W.d.b. heeft geen van deze beide termen. Het bedrag van een

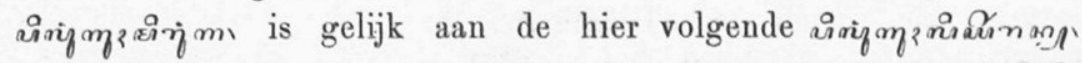
te betalen aan den apanagehouder, bij overdracht van het Bĕkĕlschap aan een desagenoot als opvolger, door den nieuwen Bĕkĕl.

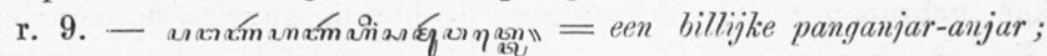
volgens "Lindresumé" een zekere som bij het optreden van een nieuwen apanagehouder door den Bĕkĕl aan dezen te betalen.

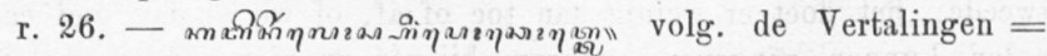
uit zigne betrekking worden ontslagen. In Art. 4 r. 10 en 14 is het:

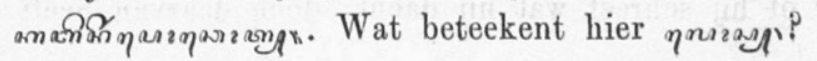




\section{Art. 7.}

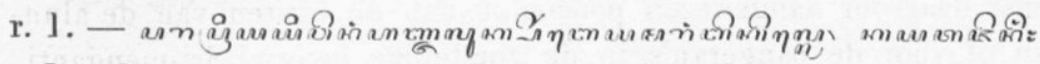

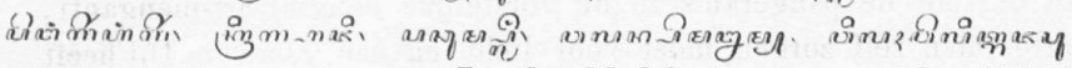

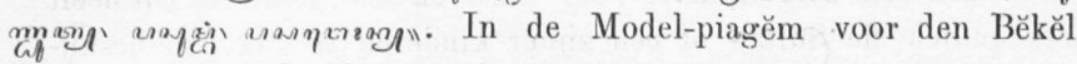
eener onverhuurde desa." (II. No 4) te vinden bij Oudemans II. p. 204 v. v., wordt opgemerkt: Onder de bovengenoemde levering zal

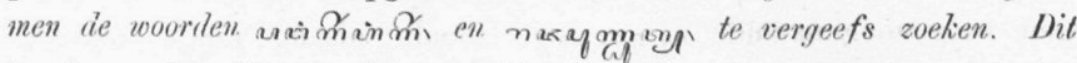
komt, omdat the leveringen zelf alle onder die termen begrepen zijn. Zie II No 16 Art. 1 waar wij lezen: "onder sà่ verstaan hetgeen Běkěl's en Děmang's op moeten brengen aun hun apanagehouders, of aan degenen die daarvoor in de plaats treden. (Lurahpatuh-gaḍuh.)" - nххутmang zijn heffingen ten behoeve van het Rijk.

De genoemde heffingen worden I. p. 205 aldus verklaard, waarbij het Lexicon kan vergeleken worden:

คำำma는 = het geld, dat de pangeran's en alle ambtenaren

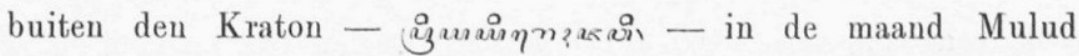
verschuldigd zijn voor de muziek, de dwergen, - tjebulan, pålä-

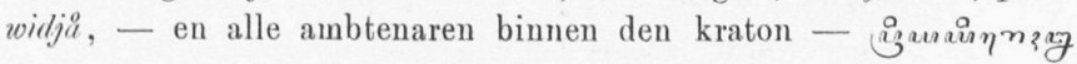

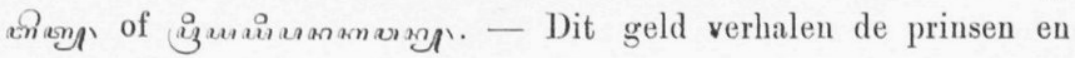
ambtenaren weder op hunne Běkěl's.

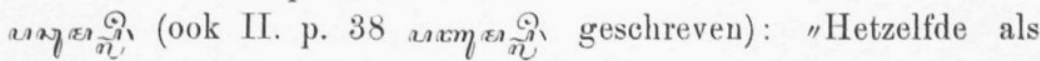

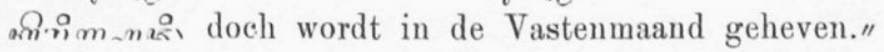

«nı⿻ vruchten, djĕnang, djuwadah, wadjiq, of andere versnaperingen.

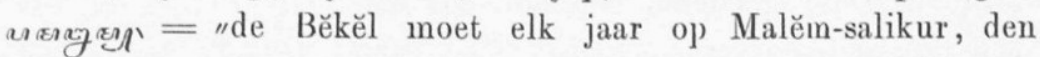
$21^{\text {en }}$ der Vastenmaand, met één Kuli en met geld bij den apanagehouder komen."

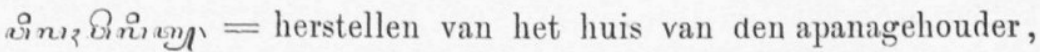
als dit reparatie behoeft. In de piagĕm wordt overeengekomen, wanneer dit plaats zal hebben, meestal in de maand Bĕsar $=12^{\mathrm{e}}$ maand. Tegenwoordig wordt echter in plaats van werkkrachten bijna altijd geld geheven, doch dan staat in de piagĕm nauwkeurig vermeld, hoeveel 's jaars."

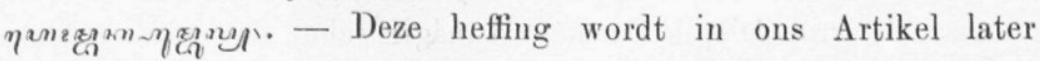
genoemd; en komt ook in de "Model-piagĕm voor den Bĕkĕl eener onverhuurde desa" voor. Zij geschiedt ten behoeve van het Rijk, en bestaat in: syórnam d. i. eenige dagen en nachten achtereen 
officieel een feest bijwonen, in eene bepaald voor elken tak van dienst daarvoor aangewezen pondọ'an aan de kanten van de alunalun of voor de pangeran's in de vorstelijke bangsal Sri-mĕnganti, waarbij men zelf zorgen moet voor licht en een gamĕlan. Dit heeft plaats indien de Sultan of een zijner kinderen trouwt, bij besnijdenissen, of als de Gouverneur-Generaal te Ngajogyå vertoeft. Bij huwelijksfeesten moet men, behalve voor licht en gamĕlan ook

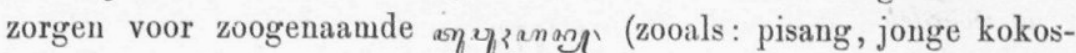
noten, ( \$ণ丶 Rijksbestierder. De kosten voor een en ander worden wederom op de Bĕkěl's verhaald.

Als men nu bedenkt, dat hier nog bijkomen: влмпах

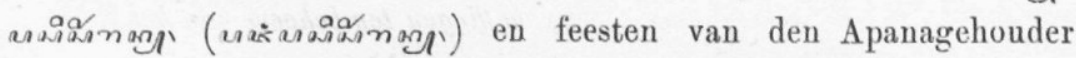
bij huwelijken, besnijdenissen, en geboorte van zijn kinderen, kan men wel zeggen, dat zulk een Inlander niet voor niemendal

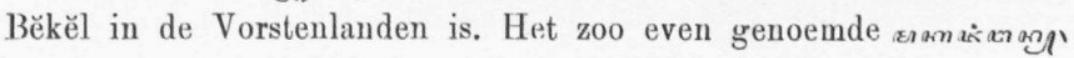

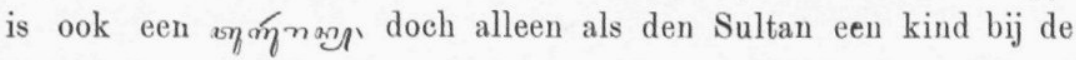

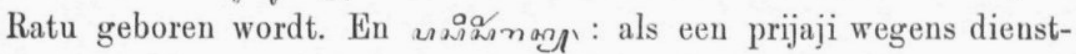
zaken uitgezonden wordt, zooals het vergezellen van het lijk vau een hoog personage naar de vorstelijke begraafplaats Padjimatan te Imågiri; het huldebewijzen bij de komst of het vertrek van een Regeerings-Commissaris; het vergezellen naar de bergen Mĕrapi en Lawu, en naar de Zuidzee van gezantschappen, die op de kroondagen van den Sultan en van den Kroonprins eenige vorstelijke goederen in den krater dier bergen of in zee gooien (= mazis $)$. Deze goederen bestaan voor het gooien in de kraters

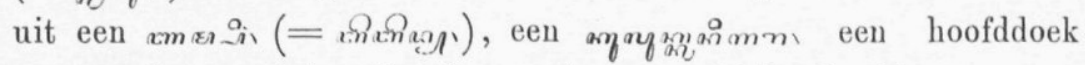

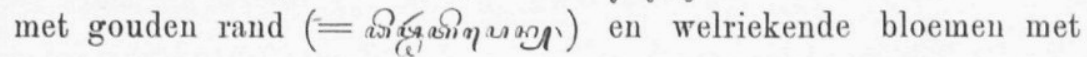

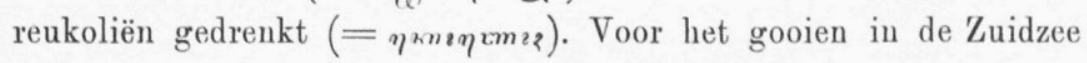
wordt de hoofddoek door een borstlap met gouden rand (ำชำ

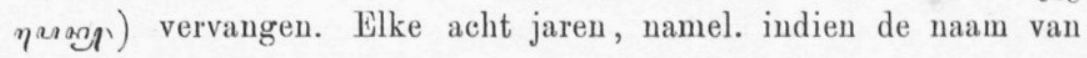
het jaar, waariu de Sultan of Kroonprins gekroond zijn, terugkeert (voor den tegenwoordigen Sultan is dit het jaar Dje, voor den nu onlangs overleden Kroonprins het jaar Alip), wordt er bovendien naar de grot Dlěpih (in het Wånågiri'sche) een gezantschap gezonden, dat daarin dezelfde goederen als in de kraters van den Mĕrapi en Lawu werpt. De Bĕkĕl's moeten op zulke tochten met of zonder kuli, al naar dat geconditioneerd wordt, hun apanage- 


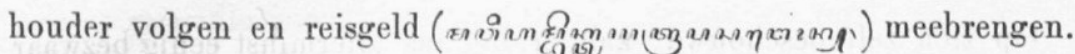
Ons Artikel schrijft dan ook uitdrukkelijk voor: Als een prijaij eenige onkosten ten behoeve van het Rijk heeft te maken, is hij bevoegd die allen van ziju Bëkèr's te vorderen, en de Běkèl's ziju gehouden die in hun geheel op te brengen overeenkomstig de gewoonte.

r. 9. - Waar zooveel door den Bĕkěl aan zijn Lurah-Patuh wordt opgebracht, of zooals 't in sommige gevallen zou kunnen heeten: het Rijk, zou men zoo denken, dat als hij zelf nu eens een feestje moet geven, zooals een kind uithuwelijken enz., hij wederkeerig iets zou mogen verwachten van zijn apanagehouder;

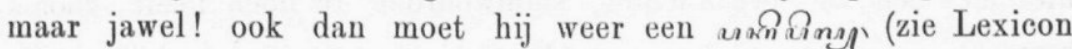
i. v. คดณnฯ eenden enz.) zijnen apanagehouder aanbieden!

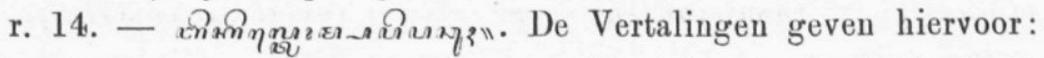
den Bèkèl met straf beulreigen, zoo dat verzuim of die weigering zich herhaalt.

\section{A r t. 8.}

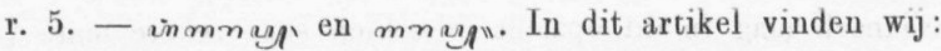

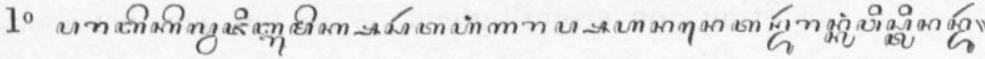

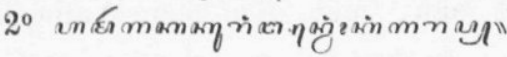

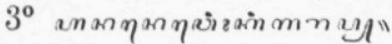

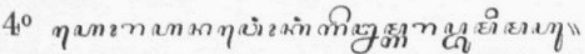

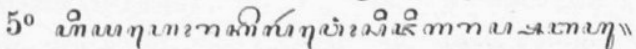

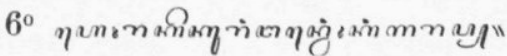

In dit ééne Artikel vinden wij alzoo éénmaal den vorm

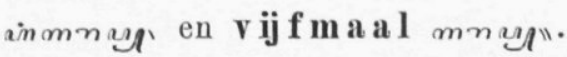

De vertalingen kunnen aldus luiden in hun verband:

$1^{\circ}$ De Bĕkěl's zijn verplicht zorg te dragen voor en te bewerken al hetgeen te velde staat.

$2^{\circ}$ wegens gebrek aan arbeiders (menschen die bewerken.)

$3^{\circ}$ de aanwezige arbeiders.

$4^{\circ}$ er geen menschen zijn welke die velden willen bewerken.

$5^{\circ}$ is toch één persoon niet in staat één bau te bewerken.

$6^{\circ}$ en geen gebrek aan arbeiders heeft.

Eenmaal met den nasaalvorm, vijfmaal zonder! Is dat nu door foutief schrijven van den auteur, of slordigheid van den copiist? Of is 't volmaakt onverschillig, of men schrijft inmmay of mกะม"? 
Op zich zelf beschouwd, kan er bij ons allerminst eenig bezwaar tegen bestaan, te zeggen dat de Javaan èn in zijn spreken èn in zijn schrijven wel eens taalkundige fouten makt. Dat weet iedereen wel! Alleen maar: de groote moeilijkheid begint daar, waar men nu ook die fouten zal dienen aan te wijzen. Niet in gevallen, als bijv. in ditzelfde Artikel, waar wij xhn

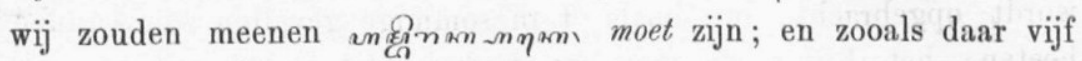
regels vroeger dan ook aangetroffen wordt. (Zie verder boven Aanteek. op Art. 1 r. 6). Maar wel in gevallen, waar men met, niet met een em beginnende, stamwoorden te doen heeft, zooals

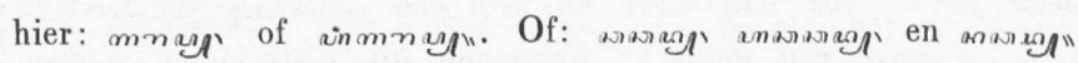

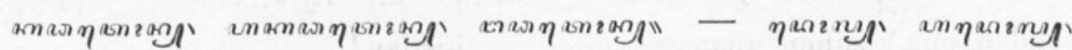

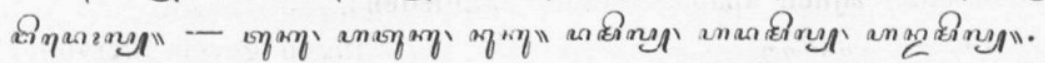

Maar geheel anders wordt de quaestie, als men van deze laatstgenoemde voorbeelden zou willen beweren, dat het volmaakt onverschillig is, of men bijv. mnay of inmnys schrijft! Het $\mathrm{N}$. Javaansch mag in dit opzicht misschien eene zekere mate van slordigheid, afslijting, onverschilligheid - of hoe men het noemen wil - vertoonen, het gaat niet aan, met den heer Walbeehm (in Tijlschr. B. B. 1898 p. 249) te zeggen: een Javaan zegt in beide gevallen, (mnмy en inmnэy): 'nggarap, daar garap als Werkwoord niet bestaat, en als hij in het eerste geval schrijft zonder neusklank (zooals men weet de regel bij Javanen) dan doet hij het ook in het tweede geval." En wat daar verder volgt. Hetgeen nog nader geïllustreerd wordt door hetgeen wij lezen in zijn: "De woorden als Zindeelen in het Javaansch." $\S 21$, p. 12: "Zoo staat in volkomen dezelfde beteekenis naast

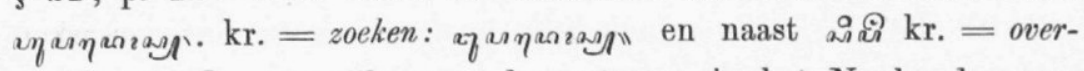

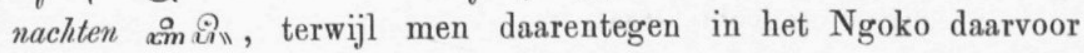

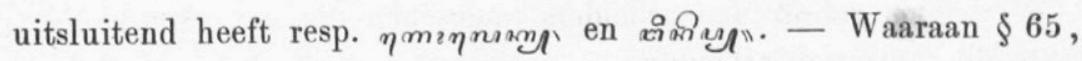
p. 31 (o. c.) zich aansluit: "zooals boven bij $\S 21$ reeds gebleken is, heeft echter niet altijd (?) het Werkwoord met den neusklank een andere beteekenis dan dat zonder neusklank, terwijl in enkele gevallen, waar aangenomen wordt, dat een onderscheid bestaat, dit niet altijd in het oog gehouden wordt." - En als dan toch, - niettegenstaande al deze onzekerheid en onbepaaldheid, zoodat men eigenlijk niet meer weet, wat van dien nasaal, die toch bestaat, te moeten denken - in $\S 35$ zeer bepaald gezegd wordt 
dat "door voorvoeging van een neusklank een Werkwoord ontstaat," dan vraagt men zich af: Hoe hebben wij 't nu met dien Nasaal? Zou het N. Javaansch dan eigenlijk in nog wanhopiger toestand, dan wijlen de heer van der Tuuk bedoelde, verkeeren, toen hij (in zijn: Taco Roorla's beoefening enz. p. 3) met cursieve letters liet drukken, dat "het .Javaansch een zeer versleten taal" is?

Maar neen! Zoo wanhopig is 't daarmee niet gesteld! 't Staat vast, dat de Javaan zoowel mn $⿻$ I als inmn schrijft, hetgeen geldt voor al dergelịke woorden. Hij moge daarbij slordig te werk gaan; hij moge zich daarbij vergissen - 't doet er niets toe. Daar zijn voorbeelden genoeg te vinden, waarin de Schrijvers het bewijs leveren, welke beteekenis de Nasaal voor hen heeft. Die beteekenis hebben wij getracht in onze "Grammatica" te omschrijven. Onze uiteenzetting moge niet op alle vragen een bevredigend antwoord gegeven hebben - de grondgedachte: de Nasaal vormt Durativen, blijft onaantastbaar. Heeft men tegen de benaming bezwaren, door er gedachten van bijv. tijdsduur aan te verbinden, dan kan dat niet voor onze rekening komen; evenmin als dat men den stamwoordelijken vorm niet als een Aorist zou willen erkennen, want onze bedoeling met die benamingen hebben wij getracht duidelijk te maken. En wil men er andere benanningen voor in de plaats stellen — zeer wel! als die maar beter de beteekenis benoemen. Gaarne nemen wij hier over, hetgeen H. J. E. Tendeloo in zijne belangwekkende dissertatie: "Maleische Verba en Nomina Verbalia" p. 64 ten opzichte van het Maleisch schreef: "Precies hetzelfde zien wij in het Maleisch met de onderseheiding tusschen بربو ت (běrbūwat) anderzijds." Ook willen wij in dit verband naar diezelfde dissertatie (p. 35, 36, 61 en 77) verwijzen, als men meenen mocht, dat een gepraefigeerde Nasaal een Transitief begrip aan eenig woord zou geven. Het transitief of intransitief zijn van een woord, heeft met die nasaleering als zoodanig niets uit te staan.

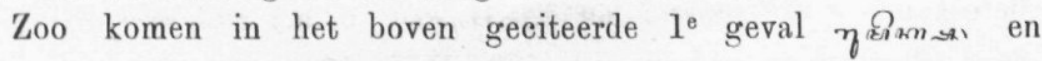
inmn $y$ voor. Het staat vast, dat het Infix $\mathbf{u}+\mathbf{m}$ iets anders beteekent dan de gepraefigeerde $\mathrm{Nasaal}$; aan het als praedicaatswoord optredende woord eene andere grammatische waarde geeft.

Voor de bepaling van de plaats der inschuiving van $\mathrm{u}+\mathrm{m}$ achten wij het nauwkeuriger te zeggen: "tussehen den consonant en vocaal der eerste aksårå", dan (zooals de heer Walbeehm o. c. 
$\S 93$, p. 4.7 zegt): "Wordt ingeschoven onmiddelijk achter de eerste aksårå van het grondwoord."

Doch van meer belang is, dat het onderscheid tusschen het Infix $\mathbf{u}+\mathbf{m}$ en het Praefix Nasaal vaststaat, en zij nooit, in geen geval, hetzelfde kunnen beteekenen. Het moet dus de aandacht treffen, als wij (o. c. $\S 94$, p. 48) lezen: "In de eerste plaats komt het Werkwoord met i de Eenvoudige werkwoorden. (Zie $\S 51$ v. v.) Evenals dáár" (bedoeld zijn "de Werkwoorden, ontstaan door voorvoeging van den neusklank") "hangt de beteekenis dan af van die van het grondwoord." Wij allerminst kunnen het af keuren, dat ook de heer Walbeehm verklaart: "hangt af van de beteekenis van het grondwoord." Maar dan begrijpen wij toch niet goed, waarom hij (Tijdschr. B $B$ p. 249) er zoo tegen opkomt, als wij evenzoo aan "de eigen beteekenis des woords" indachtig maken. Doch dit daar gelaten. Wij hebben in onze Grammatica $\S 89$ getracht, de grammatische waarde van het Infix $u+m$ aan te geven. Noch van den gepraefigeerden Nasaal, noch van het Infix $\mathrm{u}+\mathrm{m}$ heeft de heer Walbeehm dat gedaan, niettegenstaande de vele voorbeelden en beteekenissen van woorden door hem opgenoemd. Wij achten al deze voorbeelden nuttig en noodig, maar het is niet voldoende. Een leerling wil nu ook wel eens weten, welke waarde hij aan zulk een Affix moet toekennen, welke de grammatische kracht daarvan is, en wanneer en waarom hij in een gegeven geval dezen of genen vorm kan of behoort te gebruiken. Een leerling vraagt:

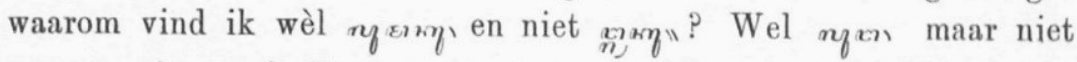

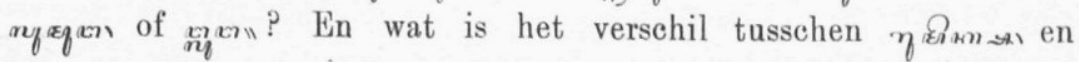

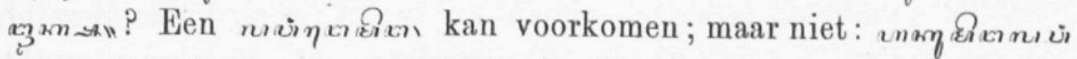
$\eta \boldsymbol{\eta} »$. Behalve met de waarde der Affixen, moet men - om dit te verklaren - ook bekend zijn met de beteekenis, die het Spraak-

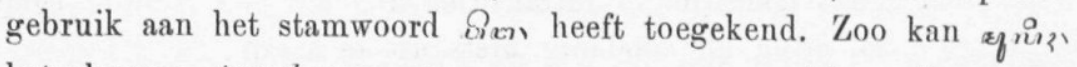

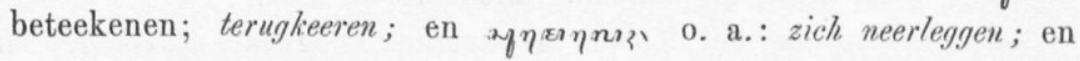

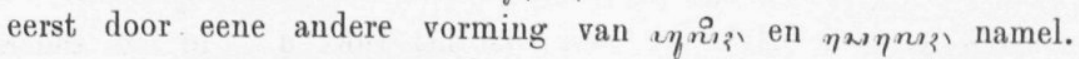
q komt een grammat. subject in betrekking tot een object.

Maar genoeg. Uit dit alles blijkt wel, dat de verklaring van de verschijnselen in eene taal eene zeer ingewikkelde zaak is; men is daarmee maar niet zoo in eens klaar, al weet men ook eene 
taal in de praktijk des levens uitnemend te gebruiken. De grammaticus zal ongetwijfeld wel eens mistasten of zich vergissen bij zijn streven de vormen eener taal te verklaren, en daarbij ook wel voor hem nog onoplosbare bezwaren blijven staan. Welkom zal ons daarom iedere bijdrage zijn om tot beter inzicht in de eigenaardigheden van het Javaansch te komen. Uit "De Woorden als Zindeelen in het Javaansch" van den heer Walbeehm is veel te leeren, en durven wij het als een nuttig boek ter kennisneming aan te bevelen. Men behoeft 't immers nog niet met alles eens te zijn, om dit te kunnen doen? Wij moeten van en met elkander leeren, ons bewust op de schouders van voorgangers te staan. Een man als Taco Roorda, die in 1855 reeds zijn kostelijke "Javaansche Grammatica s schreef, staat daarom hoog, zeer hoog bij ons, en trachten wij in zijnen geest voort te werken. Komen wij dat doende tot eene andere wijze van voorstellen, zelfs op enkele punten tot andere resultaten - wat nood? Als 't ons gegeven wordt een steentje aan te dragen tot den opbouw van de Wetenschap, zij ons dat eere genoeg! Ons leven is te kort en te kostbaar, en onze kennis te beperkt, dan dat wij lust zouden kunnen gevoelen mee te werken aan het afbreken van reputatiën, waarbij zooveel waarheid verloren en zoek raakt! De Wetenschap wordt er allerminst door gediend!

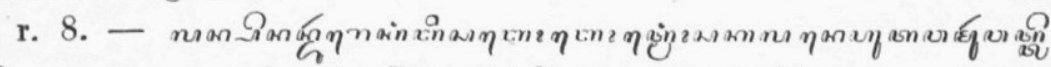

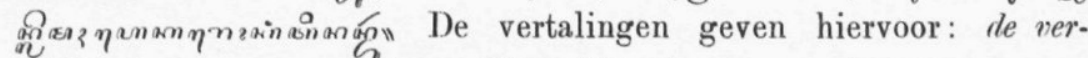
schillende gewassen op de geschikte tijden in den grond te brengen, en ten aanzien van de keuze der te verbouwen gevassen, rekening te houden met de gesteldheid der gronden. - sinconas een qualitative (modale) Voluntatief. Zie Grammat. § 103 en 161. - Walbeehm. o. c. \$§.

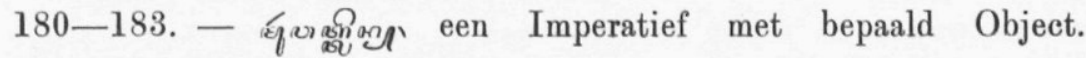
Grammat. $\S 111$. - Voorts dient hier ten opzichte van den Javaanschen zin opgemerkt te worden, dat hier $1^{\circ}$ iets van asang $\eta$ v = het planten (niet van de gewassen) gezegd wordt; dat dit planten

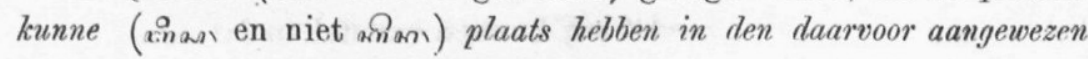

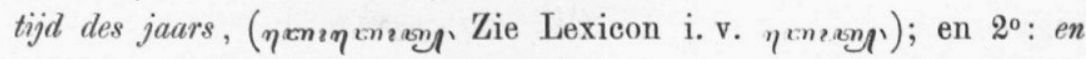
(= s.yones Grammat. $\$ 177$ p. 350) houdt rekening met de gronden in verband tot (of: en) hetgeen geplant wordt.

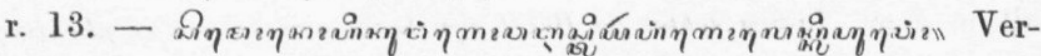
taling O.: In dat geval moet men trachten menschen te zoeken. Het 
"Eindresumé" heeft: De Bělě̀l is echter in het laatstliedoeld geval nerplicht het noodige te doen om het ontlorekende aantal menschen aan

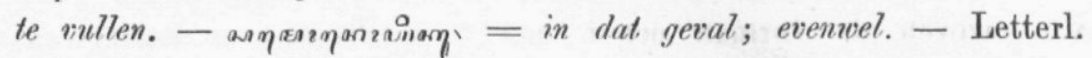
staat er: Evenwel moet hiij (de Bĕkĕl) middelen aanwenden (pogingen in het werk stellen) in het bestaande gebrek te voorzien door menschen te zoeken.

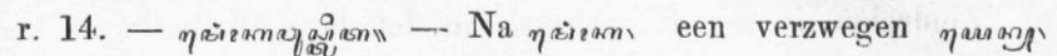

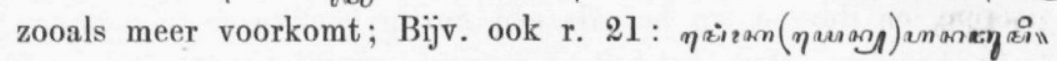

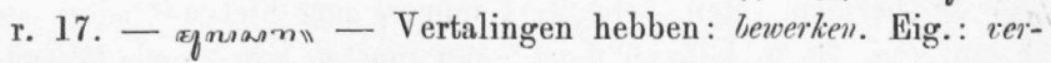
zorgen; aan den grond zijn zorg besteden door er het noodige aan te doen. - 4 regels verder is het: mny in een zelfde verband.

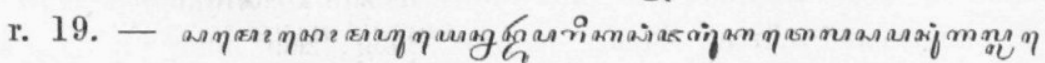

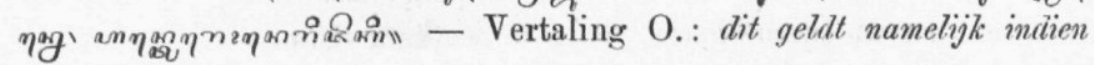
men padi, katjang, dyagung, katela en andere voedingsgevassen plant. - In "Eindresumé" : als van padi..... en andere inlandsche

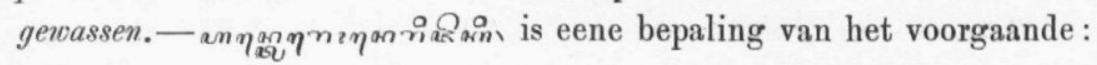
alles wat tot voedings- of levensmidlel (van den Inlander) dient.

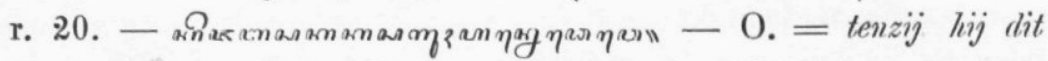
zelf aanneemt. - Het "Eindresumé heeft hier blijkbaar een andere lezing gevolgd, want het heeft: tervijl bij de cultuur van andere gewassen, slechts met toestemming van den betrokken landbouwer, aan hem een gezamenlijk aandeel in de bouwvelden van één bouw of meer kan gegeven worden; waarvan weer niets bij $\mathrm{O}$. voorkomt, evenmin als het "Eindresumé" iets van den tekst van $O$. heeft.

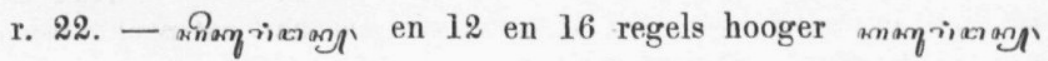
doch 3 regels verder vindt men een snonต́nma" Bij deze bekende - maar daarom niet minder af te keuren, soms lastige onregelmatigheid in het schrijven van overgelaten te bepalen wat er behoort te staan. Verklaarbaar is deze onregelmatigheid, omdat zij alleen kan voorkomen in een woordvorm van minstens drie lettergrepen. En verder door de eigen

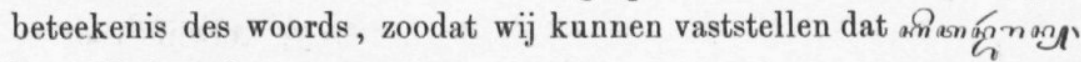
bepaald fout is.

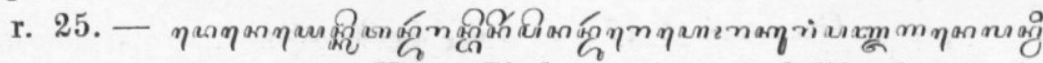

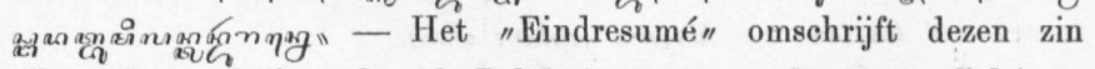
alleen door: Indien echter de Bëkël zijn boven-omschreven verplichtingen naar behooren nakomt," doch $\mathrm{O}$. geeft: Indien echter alle gronden goed beplant zijn geworden, het onderhoud niets te wenschen heeft over6e Volgr. V. 
gelaten, en het gewone gewas geplant is. - Voor: goed = had ook: naar eisch of behooren kunnen gegeven zijn. - De deri-

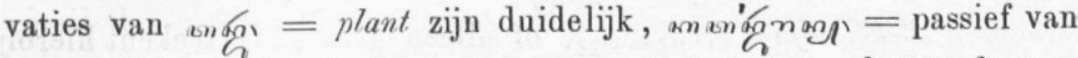

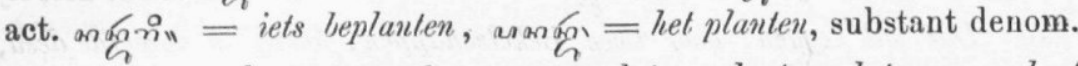

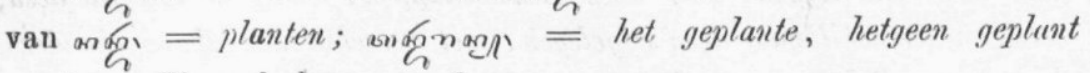
werd. - Zie ook boven r. 8 .

\section{A r t. 9.}

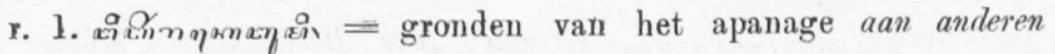
overdragen of weggeven, ten nadeele van den apanagehouder.

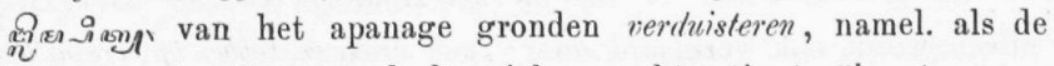
Běkěl meer dan het $\frac{1}{5}$ gedeelte zich onrechtmatig toeëigent.

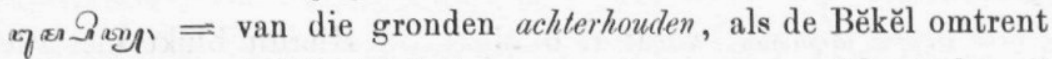
gronden die werkelijk tot het apanage behooren, verklaart dat zij daar niet toe behooren.

Aldus de vertalingen. Het Lexicon heeft het eerste niet. -

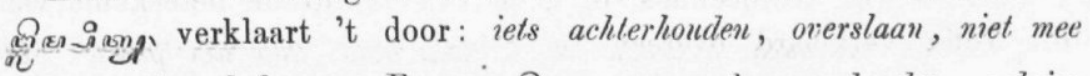

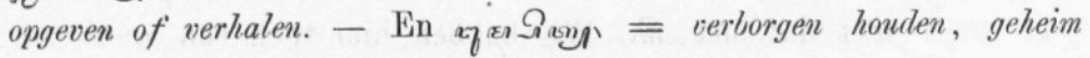

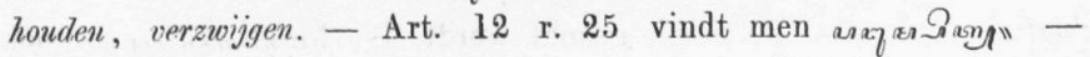
Volgens hetgeen wij verder lezen, wordt een Bĕkĕl gestraft voor $1^{\circ}$ met ontslag uit zijn Běkělschap. Voor $2^{\circ}$ met eene schadleloosstelling gelijk aan het dubbele van den opbrengst gedurende den tijd dat hij dat meer dan $\frac{1}{5}$ gedeelte der gronden voor zich heeft behouden. En voor $3^{\circ}$ met dubbel terug te geven de opbrengst der niet opgegeven gronden en eene boete ten bedrage van één-halfjaar-pacht van al de sawah's tot zijn Bĕkělschap behoorende.

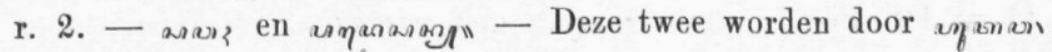
van elkaar onderscheiden. Met asталамд worden dan de gronden bedoeld, die geen м⿻љљ zijn, zooals: erven, tĕgal's enz.

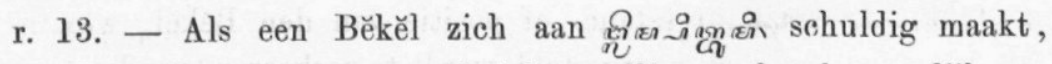
wordt hij gestraft met eene schadeloosstelling te betalen, gelijk aan

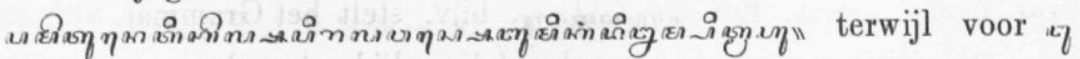

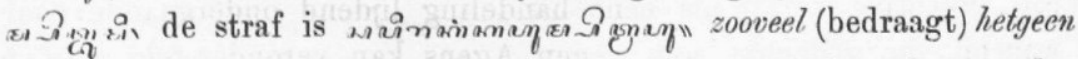
verzwegen is geworden. Maar het eerste geeft geen zin, als men dat woordelijk vertaalt: zoolang de duur is van de gronden die door hem achtergehouden werden, of van die door hem achtergehouden gronden. De vertalingen geven: gedurende den tijd der verduistering. Zoo zal ook wel de bedoeling des wetgevers zijn. 
A. t. 10.

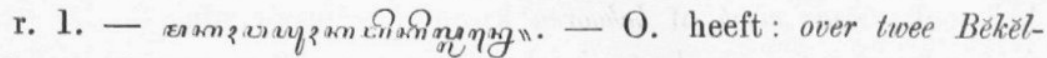

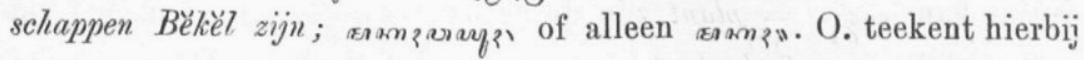
aan: Dat wil zeggen: oner twee Bĕkělschappen, helzij in dezelfde desa, hetzij in verschillende desa's gelegen, met verschillende apanagehouders. Krijgt een Bekèl er een Bëkèlschap bij in dezelfile desa met denzelfilen apanagehouder, dan is dit geoorloofd, want dan vormen dc twee Berkælschappen te zamen één nieuw Běkělschap. -- Het W.d.b. i. v. влапฉ

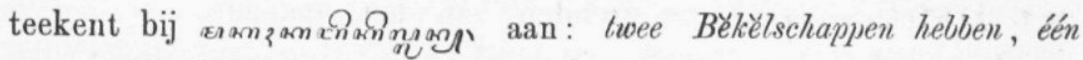

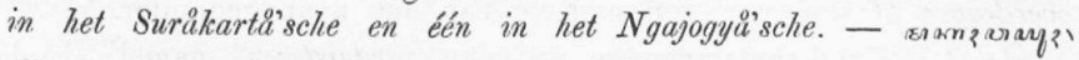
alleen wordt ook verklaard door: twee vrouwen heblen op verschillende plaatsen.

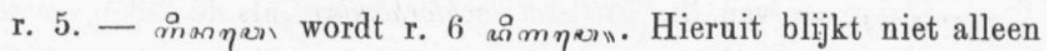
het nog voortdurend gebruik van Infix $\mathbf{i}+\mathbf{n}$, maar ook dat de waarde $\operatorname{van} \mathbf{i}+\mathbf{n}$ en $\mathbf{d} \mathbf{i}$ gelijk geacht wordt. Zie Grammat. $\S 104$. - In Walbeehm's o. c. $\S 142$ wordt de beteekenis van dit Infix verklaard overeen te komen soms met het passief met, sm soms met dat met $\mathrm{s}$. Wij hebben hier toch een voorbeeld, dat 't ook aan 오 gelijk geacht wordt. Is ํำ

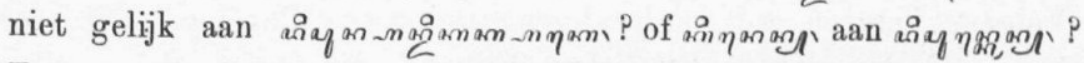
Trouwens in het O. Jav. had $\mathbf{i}+\mathbf{n}$ reeds Durative waarde.

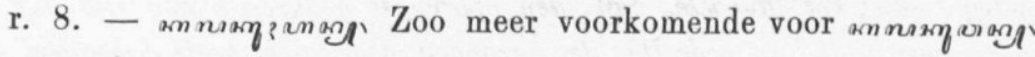
van an + nıs + enangl".

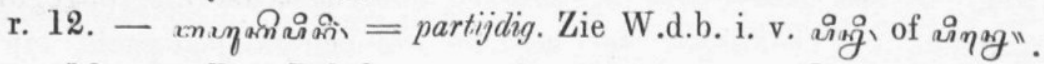

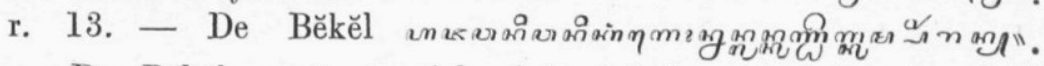
O. = De Bĕkĕl verstoute zich niet misdadigers te huisvesten of bij zich te ontvangen. Wij hebben hier driemaal een ${ }^{\prime}$, passief. Naar den vorm met on geven de woorden te kennen een (Objective) gesteldheid, staat, toestand of positie van den Bĕkĕl, waarin hij als grammat. subject voorgesteld wordt te verkeeren, zonder toedoen

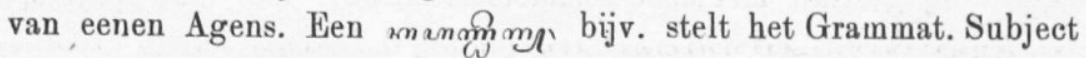
(op objective wijze) als eene handeling lijdend ondergaande voor, waarbij de gedachte aan eenen Agens kan verondersteld worden. Het an passief duidt op een objectief $\mathbf{z} \mathbf{i j} \mathbf{u}$ of bestaan; het am passief op een objectief worden; bij het eerste is de gedachte aan een $\mathbf{A}$ gens absoluut uitgesloten; bij het tweede te veronderstellen. Zie Grammat. $\S 100$. - Voor den conjunctiefvorm 


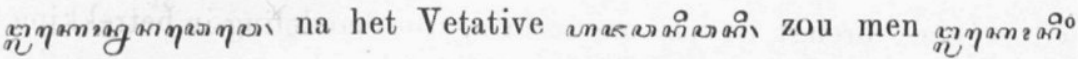
verwachtèn.

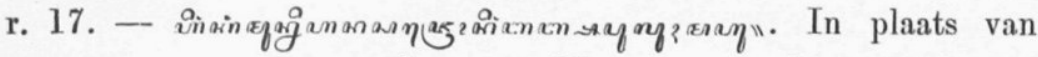
ainsin zou men sin verwachten. - Maar waartoe dient dat anas? Ook zonder dat aman zou de zin volledig geacht kunnen worden. Zie Grammat. $\S 169$, p. 306 .

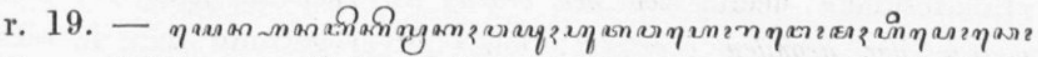

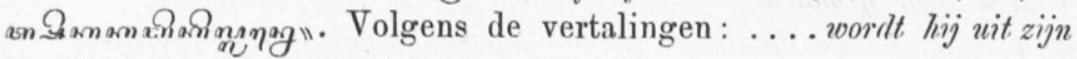
Běǩlschap ontslagen. In het Javaansch is iets uitgevallen; misschien

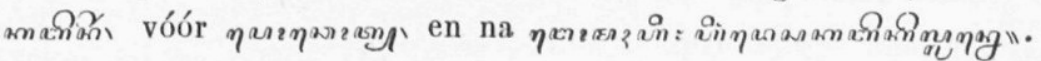

r. 21. - y

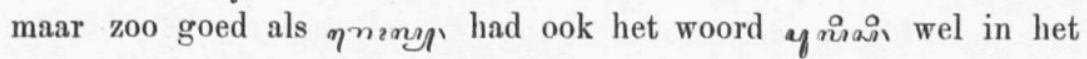
W.d.b. kunnen opgenomen worden.

\section{A r. 11.}

r. 2. - aińgr

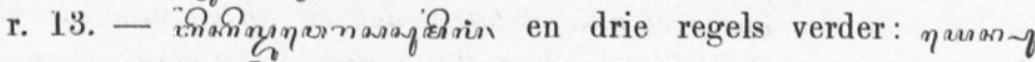

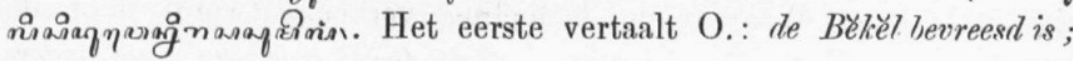
maar "Eindresumé": de zaak verdacht voorkomt. En het tweede beiden door: de politie (politiehoofl. "Eindresumé") de zaak verdacht voorkomt. Het zou ook omschreven kunnen worden door: een gevoel van verlegenheid met het geval of de zaak hebben. - Maar waarom

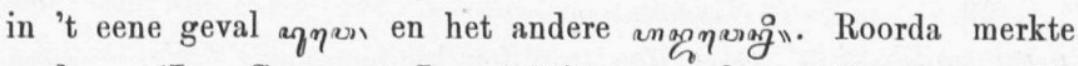

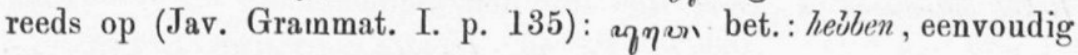
als een accident dat plaats heeft, maar als een daad die van het subject uitgaat anapqorg. is geen lijdelijk hebben, maar een bezitten van een voorwerp door iemands magt of werking op dat voorwerp, een in en onder zijn magt hebben, een hebben of bezitten, waarvan de bezitter de benerker, of oorzaak is enz." Zoo ook hier. In het eerste geval wil de schrijver alleen maar van den Bĕkĕl zeggen, dat hij die nasagधिis heeft, dat die bij hem aanwezig is, zonder meer. Maar in het tweede geval, dat het Politiehoofd, ja, ook

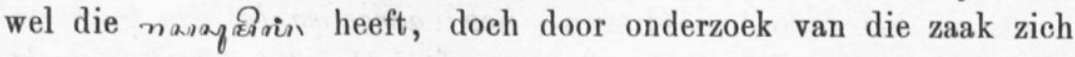
die voorstelling, die nas heeft eigen gemaakt, dat hij door werkzaam zijn en als gevolg daarvan die nas heeft verkregen. Waar de stamwoordelijke vorm aq 
wil zeggen, brengt de in aanhechting die handeling in betrekking tot een Object. Zie Grammat. $§ 92$.

\section{A r t. 12.}

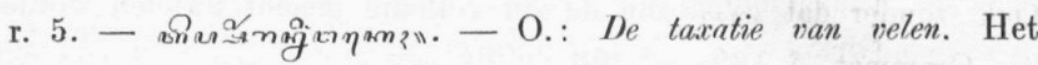
"Eindresumé" heeft: zoo het bedrag der pacht de getareerde pachtwaarde der gronden overtreft, enz." Meer getrouw zegt de tekst: de tuxatie van de desalieden in het algemeen, van de groote meerderheid, het publiek. Hierbij zij opgemerkt, dat ona $\stackrel{a}{a n a n}$ (zie W.d.b. i. v.

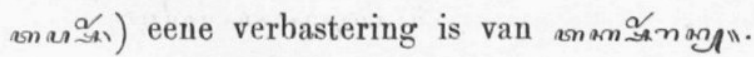

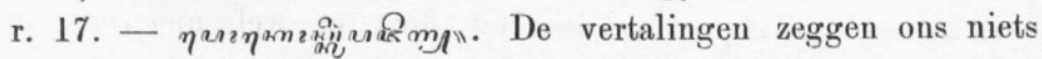
tot goed begrip dezer uitdrukking. Zij zal ongeveer beteekenen : volgens den grondslag, het eenmaal vastgestelde bedrag der padjëg.

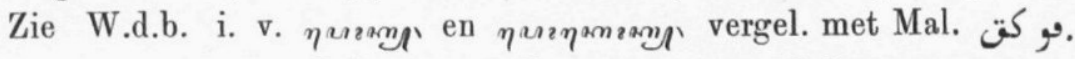

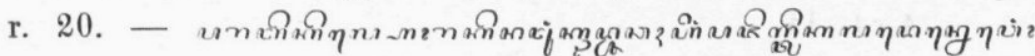

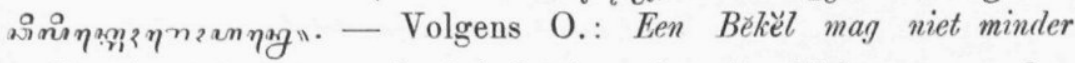
padièg (aan den apanagehouder) betalen, dan zïn Klein-man aan hem opgebracht heeft. Waarvan de bedoeling verklaard wordt door de vertaling van het "Eindresumé": "Een Bèkèl mag van zijne onderhoorigen niet meer pacht vorderen dan zij nerschuldigd zijn. M. a. w.: een Běkěl moet het van zijn onderhoorigen ontvangen bedrag padjĕg onverminderd aan den prijaji afdragen.

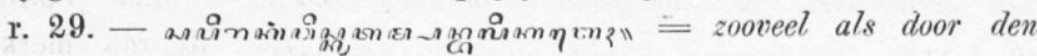
Běkěl ontvangen is, keert alles (tot den kleinen man) terug. - anan

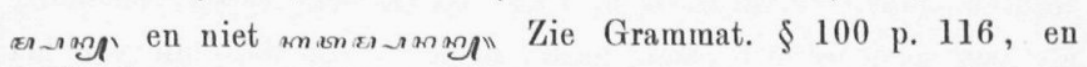
Walbeehm o. c. $\S 130$ p. 66.

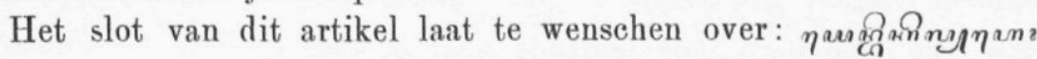

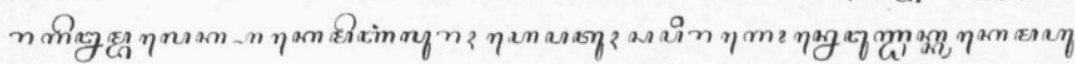

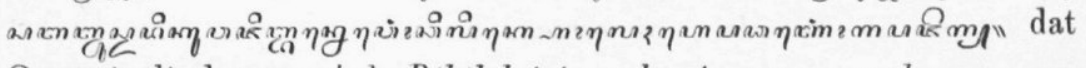
O. vertaalt door: zal de Běkěl het te veel ontnangene aan den apanagehouder moeten aflragen, omdat het betalen van pacht inderdaad tot de verplichtingen van den Kleinen Man behoort." Maar "Eindresumé" heeft na het woord "afdragen" nog: aangezien het dan beschouwd wordt, dat de onderhoorigen, die de pacht hebben betaald, haar rechtmatig aan den apanagehouler verschuldigd waren." - Onze tekst geeft woordelijk: als de Běkěl niet wil teruggeven aan den LurahPatuh zooveeel sijn te veel padjèg-invarderen bedraagt.... want het 
is nu eenmaal een plicht van den Kleinen Mlan dat hij parjĕg oplrengt. De zaak komt hierop neer; als de bevolking zich beklaagt wegens te veel geïnde padjĕg, dan moet de Bĕkĕl dat te veel aan de bevolking teruggeven, of hij wordt bij weigering ontslagen. Maar dient de apanagehouder die klacht in, dan moet dat te veel geïnde door den Bĕkĕl aan den apanagehouder afgedragen worden, aangezien enz. zooals het "Eindresumé" verder geeft. 